Key Words:

STREAM II

Aqueous Transport

WIND System

Retention:

\#Permanent\#

\title{
STREAM II-V5: REVISION OF STREAM II-V4 TO ACCOUNT FOR THE EFFECTS OF RAINFALL EVENTS
}

\author{
Author: Kuo-Fu Chen
}

FEBRUARY 1, 2010

Savannah River National Laboratory

Savannah River Nuclear Solutions

Aiken, SC 29808

Prepared for the U.S. Department of Energy Under

Contract Number DE-AC09-08SR22470

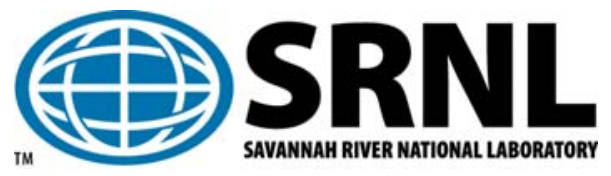




\section{DISCLAIMER}

This work was prepared under an agreement with and funded by the U.S. Government. Neither the U. S. Government or its employees, nor any of its contractors, subcontractors or their employees, makes any express or implied:

1. warranty or assumes any legal liability for the accuracy, completeness, or for the use or results of such use of any information, product, or process disclosed; or

2. representation that such use or results of such use would not infringe privately owned rights; or

3. endorsement or recommendation of any specifically identified commercial product, process, or service.

Any views and opinions of authors expressed in this work do not necessarily state or reflect those of the United States Government, or its contractors, or subcontractors.

Printed in the United States of America

Prepared for

U.S. Department of Energy 
Key Words:

STREAM II

Aqueous Transport

WIND System

Retention:

\#Permanent\#

\title{
STREAM II-V5: REVISION OF STREAM II-V4 TO ACCOUNT FOR THE EFFECTS OF RAINFALL EVENTS
}

\author{
Author: Kuo-Fu Chen
}

FEBRUARY 1, 2010

Savannah River National Laboratory

Savannah River Nuclear Solutions

Savannah River Site

Aiken, SC 29808

Prepared for the U.S. Department of Energy Under

Contract Number DE-AC09-08SR22470 


\section{REVIEWS AND APPROVALS}

Kuo-Fu Chen, Author, Atmospheric Technologies Group

Date

Robert L. Buckley, Technical Reviewer, Atmospheric Technologies Group

Date

Charles H. Hunter, Level 4 Manager, Atmospheric Technologies Group

Date

Robert P. Addis, Level 3 Manager, National and Homeland Security

Date 


\begin{abstract}
STREAM II-V4 is the aqueous transport module currently used by the Savannah River Site emergency response Weather Information Display (WIND) system. The transport model of

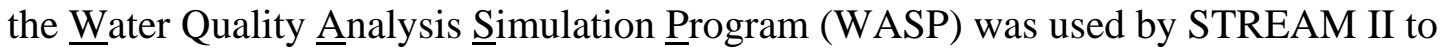
perform contaminant transport calculations. WASP5 is a US Environmental Protection Agency (EPA) water quality analysis program that simulates contaminant transport and fate through surface water. STREAM II-V4 predicts peak concentration and peak concentration arrival time at downstream locations for releases from the SRS facilities to the Savannah River. The input flows for STREAM II-V4 are derived from the historical flow records measured by the United States Geological Survey (USGS). The stream flow for STREAM II-V4 is fixed and the flow only varies with the month in which the releases are taking place. Therefore, the effects of flow surge due to a severe storm are not accounted for by STREAM II-V4.

STREAM II-V4 has been revised to account for the effects of a storm event. The steps used in this method are: 1 ) generate rainfall hyetographs as a function of total rainfall in inches (or millimeters) and rainfall duration in hours; 2) generate watershed runoff flow based on the rainfall hyetographs from step 1 ; 3) calculate the variation of stream segment volume (cross section) as a function of flow from step 2; 4) implement the results from steps 2 and 3 into the STREAM II model. The revised model (STREAM II-V5) will find the proper stream inlet flow based on the total rainfall and rainfall duration as input by the user. STREAM IIV5 adjusts the stream segment volumes (cross sections) based on the stream inlet flow. The rainfall based stream flow and the adjusted stream segment volumes are then used for contaminant transport calculations.
\end{abstract}




\section{TABLE OF CONTENTS}

1. INTRODUCTION 1

2. DESIGN RAINFALL HYETOGRAPH 1

2.1 Derivation of 24-Hour Rainfall Hyetograph 2

2.2 Derivation of 12-Hour Rainfall Hyetograph 2

2.3 Derivation of 6-Hour Rainfall Hyetograph 3

2.4 Derivation of 3-Hour Rainfall Hyetograph 3

3. WATERSHED DELINEATION 4

4. WATERSHED RUNOFF 4

4.1 Upper Three Runs 5

4.2 Beaver Dam Creek $\quad 5$

4.3 Fourmile Branch $\quad 5$

4.4 Pen Branch $\quad 6$

4.5 Steel Creek 6

4.6 Lower Three Runs 6

4.7 Savannah River $\quad 7$

5. STREAM SEGMENT VOLUME AS A FUNCTION OF RUNOFF FLOW 7

6. CODE MODIFICATIONS 7

7. TEST RESULTS $\quad 8$

7.1 STREAM II-V4 vs. STREAM II-V5 8

7.2 Rainfall Effects $\quad 9$

8. CONCLUSION 10

$\begin{array}{ll}\text { ACKNOWLEDGEMENT } & 11\end{array}$

REFERENCES 12 


\section{LIST OF TABLES}

Table 1. 6-Hour Rainfall Distribution as a Function of Return Period

Table 2. 24-Hour Rainfall Distribution as a Function of Return Period

15

Table 3. Design Rainfall Events for STREAM II-V5

16

Table 4. HEC-HMS Input Parameters

17

Table 5. Model Comparison between STREAM II-V4 and -V5

18

Table 6. Effects of Rainfall on Contaminant Transport

20 


\section{LIST OF FIGURES}

Figure 1. 24-Hour Storm Rainfall Distributions 23

Figure 2. 12-Hour Storm Rainfall Distributions $\quad 24$

Figure 3. 6-Hour Storm Rainfall Distributions $\quad 25$

Figure 4. 3-Hour Storm Rainfall Distributions 26

Figure 5. Digital Elevation Model for Savannah River Site 27

Figure 6. Streams Delineated by HEC-GeoHMS 28

Figure 7. Watershed Delineated by HEC-GeoHMS 29

Figure 8. Upper Three Runs Watershed 30

Figure 9. Fourmile Branch Watershed 31

Figure 10. Pen Branch Watershed 32

Figure 11. Steel Creek Watershed 33

Figure 12. Lower Three Runs Watershed 34

Figure 13. HEC-HMS Simulation for the Upper Three Runs Watershed

Runoff Hydrograph (2.8 Inches of Rainfall in 3 Hours) 35

Figure 14. Upper Three Runs Peak Runoff Flow as a Function of Total Rainfall (Rainfall Duration=1 Hour) 36

Figure 15. Upper Three Runs Peak Runoff Flow as a Function of Total Rainfall (Rainfall Duration=3 Hours) 37

Figure 16. Upper Three Runs Peak Runoff Flow as a Function of Total Rainfall (Rainfall Duration=6 Hours) 38

Figure 17. Upper Three Runs Peak Runoff Flow as a Function of Total Rainfall (Rainfall Duration=12 Hours) 39

Figure 18. Upper Three Runs Peak Runoff Flow as a Function of Total Rainfall (Rainfall Duration=24 Hours) 40

Figure 19. Fourmile Branch Peak Runoff Flow as a Function of Total Rainfall (Rainfall Duration=1 Hour)

Figure 20. Fourmile Branch Peak Runoff Flow as a Function of Total Rainfall (Rainfall Duration=3 Hours) 42

Figure 21. Fourmile Branch Peak Runoff Flow as a Function of Total Rainfall (Rainfall Duration=6 Hours) 43

Figure 22. Fourmile Branch Peak Runoff Flow as a Function of Total Rainfall (Rainfall Duration=12 Hours) 44

Figure 23. Fourmile Branch Peak Runoff Flow as a Function of Total Rainfall (Rainfall Duration=24 Hours) 45

Figure 24. Pen Branch Peak Runoff Flow as a Function of Total Rainfall (Rainfall Duration=1 Hour) 46

Figure 25. Pen Branch Peak Runoff Flow as a Function of Total Rainfall (Rainfall Duration=3 Hours) 47

Figure 26. Pen Branch Peak Runoff Flow as a Function of Total Rainfall (Rainfall Duration=6 Hours) 48

Figure 27. Pen Branch Peak Runoff Flow as a Function of Total Rainfall (Rainfall Duration=12 Hours)

Figure 28. Pen Branch Peak Runoff Flow as a Function of Total Rainfall (Rainfall Duration=24 Hours) 
Figure 29. Steel Creek Peak Runoff Flow as a Function of Total Rainfall (Rainfall Duration=1 Hour)

Figure 30. Steel Creek Peak Runoff Flow as a Function of

Total Rainfall (Rainfall Duration=3 Hours) 52

Figure 31. Steel Creek Peak Runoff Flow as a Function of

Total Rainfall (Rainfall Duration=6 Hours) 53

Figure 32. Steel Creek Peak Runoff Flow as a Function of

Total Rainfall (Rainfall Duration=12 Hours) 54

Figure 33. Steel Creek Peak Runoff Flow as a Function of

Total Rainfall (Rainfall Duration=24 Hours) 55

Figure 34. Lower Three Runs Peak Runoff Flow as a Function of

Total Rainfall (Rainfall Duration=1 Hour) 56

Figure 35. Lower Three Runs Peak Runoff Flow as a Function of

Total Rainfall (Rainfall Duration=3 Hours) 57

Figure 36. Lower Three Runs Peak Runoff Flow as a Function of

Total Rainfall (Rainfall Duration=6 Hours) 58

Figure 37. Lower Three Runs Peak Runoff Flow as a Function of

Total Rainfall (Rainfall Duration=12 Hours) 59

Figure 38. Lower Three Runs Peak Runoff Flow as a Function of

Total Rainfall (Rainfall Duration=24 Hours) 60

Figure 39. Calculated Upper Three Runs Segment Volume as a

Function of Flow (Segment Size: 500 Meters) 61

Figure 40. Calculated McQueen Branch Segment Volume as a

Function of Flow (Segment Size: 500 Meters) 62

Figure 41. Calculated Tims Branch Segment Volume as a

Function of Flow (Segment Size: 500 Meters) 63

Figure 42. Calculated Fourmile Branch Segment Volume as a

Function of Flow (Segment Size: 150 Meters) 64

Figure 43. Calculated Pen Branch Segment Volume as a

Function of Flow (Segment Size: 500 Meters) 65

Figure 44. Calculated Steel Creek Segment Volume as a

Function of Flow (Segment Size: 500 Meters) 66

Figure 45. Calculated Lower Three Runs Segment Volume as a

Function of Flow (Segment Size: 500 Meters) 67

Figure 46. Calculated Savannah River Segment Volume as a

Function of Flow (Segment Size: 500 Meters) 68

Figure 47. STREAM II-V5 Graphical User Interface $\quad 69$

Figure 48. Comparison of Model Predictions for the Peak Concentrations

(STREAM II-V5 vs. STREAM II-V4) 70

Figure 49. Comparison of Model Predictions for the Peak Concentration

Arrival Time (STREAM II-V5 vs. STREAM II-V4) 71

Figure 50. Effects of Rainfall on the Predicted Peak Concentration

Arrival Time (Rainfall 1 inch in 3 Hours vs. No Rainfall) 72

Figure 51. Effects of Rainfall on the Predicted Peak Concentration

(Rainfall 1 inch in 3 Hours vs. No rainfall) 
Blank Page

- viii - 


\section{INTRODUCTION}

STREAM II-V4 [1] is the aqueous transport module currently used by the Savannah River Site emergency response Weather Information Display (WIND) system [2]. The transport

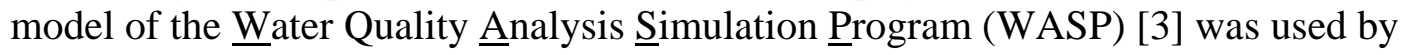
STREAM II to perform contaminant transport calculations. WASP5 is a US Environmental Protection Agency (EPA) water quality analysis program that simulates contaminant transport and fate through surface water. STREAM II-V4 predicts peak concentration and peak concentration arrival time at downstream locations for releases from the SRS facilities to the Savannah River. The input flows for STREAM II-V4 are derived from the historical flow records measured by the United States Geological Survey (USGS). The stream flow for STREAM II-V4 is fixed and the flow only varies with the month in which the releases are taking place. Therefore, the effects of flow surge due to a severe storm are not accounted for by STREAM II-V4.

Recently, STREAM II-V4 has been revised to account for the effects of a storm event. The ideal method to address this concern is to use the real time stream flows as input to the STREAM II. This method requires significant infrastructure investment for setting up a stream gauge network and automatic stream data transmission, collection and storage, and long term network maintenance. Some of the stream monitors at the SRS streams were eliminated in the past several years due to budget constraints. Therefore, an alternate method is pursued. The steps used in this method are: 1) generate rainfall hyetographs as a function of total rainfall in inches (or millimeters) and rainfall duration in hours, 2) generate watershed runoff flow based on the rainfall hyetographs from step 1, 3) calculate the variation of stream segment volume (cross section) as a function of flow from step 2, 4) implement the results from steps 2 and 3 into the STREAM II model. The revised model (STREAM II-V5) will find the proper stream inlet flow based on the total rainfall and rainfall duration as input by the user. STREAM II-V5 adjusts the stream segment volumes (cross sections) based on the stream inlet flow. The rainfall based stream flow and the adjusted stream segment volumes are then used for contaminant transport calculations. This report documents the revisions incorporated into STREAM II-V5.

\section{DESIGN RAINFALL HYETOGRAPH}

A hyetograph is a graphical representation of the distribution of rainfall over time. This section describes the method to develop design rainfall hyetographs to represent the Savannah River Site (SRS). Table 1 shows the design six-hour extreme precipitation hyetograph obtained from Reference 4, and Table 2 presents the design 24-hour extreme precipitation hyetograph obtained from Reference 5. Both design extreme precipitation hyetographs were developed specifically for SRS based on historical data at or near SRS. Table 3 summarizes the list of rainfall events that were developed for the STREAM II-V5 model. Note that the range of total rainfall shown in Table 3 was chosen to cover possible extreme rainfall events as defined by Tables 1 and 2, and a sufficient number of points were selected to be used to develop functions that represent the watershed peak runoff flow as a function of total rainfall for various rainfall durations. A rainfall duration of 1 hour is 
assumed for those rainfall events less than 1 hour, and a rainfall duration of 24 hours is assumed for those rainfall events greater than 24 hours. The watershed peak runoff flow is then interpolated for rainfall events with a duration other than those listed in Table 3. Tables 1 and 2 were used to develop the rainfall distributions for the rainfall events shown in Table 3.

\subsection{DERIVATION OF 24-HOUR RAINFALL HYETOGRAPH}

The rainfall distributions for 50-, 100- and 500-year return storm events in Table 2 were used to develop a composite rainfall distribution for the 24-hour rainfall events shown in Table 3 . The steps are described next.

The normalized composite precipitation distribution for a 24-hour rainfall event is expressed as:

$$
C_{i}^{24}=\frac{A_{i}^{24}}{B^{24}} \quad i=1,2,3, \ldots, 24 \text { hour }
$$

where the superscript of 24 represents a 24-hour rainfall event, and

$$
A_{i}^{24}=\frac{1}{3}\left(r_{i}^{24,50}+r_{i}^{24,100}+r_{i}^{24,500}\right) .
$$

The superscripts 50, 100, 500 represent 50-, 100- and 500-year return period storms, respectively, and the terms $r_{i}^{24,50}, r_{i}^{24,100}$ and $r_{i}^{24,500}$ are rainfall increments obtained from

Table 2. Also,

$$
B^{24}=\frac{1}{24} \sum_{i=1}^{24} A_{i}^{24}
$$

The precipitation distributions for a total rainfall of $X^{24}$ inches in 24 hours is

$$
R_{i}^{X, 24}=X^{24} C_{i}^{24}
$$

The value of $X^{24}$ varies from 2.4 to 12.0 inches and the values of Eq. 4 are plotted in Figure 1.

\subsection{DERIVATION OF 12-HOUR RAINFALL HYETOGRAPH}

The normalized composite precipitation distribution for the 12-hour rainfall events is derived from the normalized composite precipitation distribution of 24-hour rainfall, Eq. 1.

$$
C_{i}^{12}=\frac{1}{2}\left(C_{2 i-1}^{24}+C_{2 i}^{24}\right) . \quad i=1,2,3, \ldots, 12 \text { hour }
$$


The precipitation distributions for a total rainfall of $X^{12}$ inches in 12 hours is

$R_{i}^{X, 12}=X^{12} C_{i}^{12}$

The value of $X^{12}$ varies from 1.2 to 7.2 inches and the values of Eq. 6 are plotted in Figure 2 .

\subsection{DERIVATION OF 6-HOUR RAINFALL DISTRIBUTION}

The derivation of rainfall distributions for the 6-hour rainfall events is the same method described in Section 2.1, except the distribution data were obtained from Table 1.

The normalized composite precipitation distribution for a 6-hour rainfall event is expressed as:

$$
C_{i}^{6}=\frac{A_{i}^{6}}{B^{6}} \quad i=1,2,3, \ldots, 6 \text { hour }
$$

where the superscript of 6 represents a 6-hour rainfall event, and

$$
A_{i}^{6}=\frac{1}{3}\left(r_{i}^{6,50}+r_{i}^{6,100}+r_{i}^{6,500}\right)
$$

The superscripts 50, 100, 500 represent the 50-, 100- and 500-year return period storms, respectively, and the terms $r_{i}^{6,50}, r_{i}^{6,100}$ and $r_{i}^{6,500}$ are rainfall increments obtained from Table 1. Also,

$$
B^{6}=\frac{1}{6} \sum_{i=1}^{6} A_{i}^{6}
$$

The precipitation distributions for a total rainfall of $X^{6}$ inches in 6 hours is

$$
R_{i}^{X, 6}=X^{6} C_{i}^{6}
$$

The value of $X^{6}$ varies from 0.6 to 4.8 inches and the values of Eq. 10 are plotted in Figure 3.

\subsection{DERIVATION OF 3-HOUR RAINFALL HYETOGRAPH}

The normalized composite precipitation distribution for a 3-hour rainfall event is derived from the normalized composite precipitation distribution of 6-hour rainfall, Eq. 7.

$$
C_{i}^{3}=\frac{1}{2}\left(C_{2 i-1}^{6}+C_{2 i}^{6}\right) \quad i=1,2,3 \text { hour }
$$


The precipitation distributions for a total rainfall of $X^{3}$ inches in 3 hours is $R_{i}^{X, 3}=X^{3} C_{i}^{3}$

The value of $X^{3}$ varies from 0.3 to 3.0 inches and the values of Eq. 12 are plotted in Figure 4.

\section{WATERSHED DELINEATION}

The basin runoff depends on the watershed characteristics and the soil type, and land cover/land use. This section describes the watershed delineation. The Hydrologic Engineering Center (HEC) of the US Army Corps of Engineers has developed a geospatial hydrologic modeling extension (GeoHMS). The HEC-GeoHMS [6] model delineates the sub-basin watershed based on the Digital Elevation Model (DEM) [7] data and is a tool extension for the Environmental System Research Institute (ESRI) ArcView 3.x, Geographic Information System [8]. HEC-GeoHMS uses ArcView and Spatial Analyst to develop hydrologic modeling input for a hydrologic modeling system developed by HEC, HEC-HMS [9]. HEC-GeoHMS analyzes the digital terrain data, delineates streams and watersheds, and transforms the drainage paths and watershed boundaries into a hydrologic data structure that represents the watershed response to precipitation.

Figure 5 shows a set of DEM data at a 30-by-30-meter resolution which covers the Savannah River Site (SRS). HEC-GeoHMS delineates the streams and watershed boundaries based on the digital elevation data shown in Figure 5. Figure 6 shows the streams delineated by the HEC-GeoHMS model in green. The streams derived by HEC-GeoHMS are in good agreement with the streams (in blue) contained in the SRS Enterprise Geospatial Information Systems (EGIS) data base, as shown in Figure 6. Figure 7 presents the sub-basin watersheds delineated by HEC-GeoHMS. Figure 8 shows the Upper Three Runs watershed which includes the Tinker Creek, McQueen Branch, and Tims Branch sub-basins. Figure 9 to 12 show the watersheds of Fourmile Branch, Pen Branch, Steel Creek and Lower Three Runs, respectively.

\section{WATERSHED RUNOFF}

This section describes the watershed (basin) runoff as a function of rainfall. HEC-HMS is used to perform the basin runoff calculations. As discussed in Section 3, HEC-HMS is a hydrologic modeling system developed by the US Army Corps of Engineers to model basin runoff hydrology. HEC-HMS performs precipitation-runoff simulations. The HEC-HMS input data are precipitation and model parameters (i.e., losses, runoff transformation and base flow) characterizing the basin properties. The output of HEC-HMS is basin runoff discharge. 


\subsection{UPPER THREE RUNS}

Upper Three Runs is the longest and northernmost system in SRS and has a drainage area of over 204.5 square miles (as determined from HEC-GeoHMS). Three main tributaries of Upper Three Runs are the Tinker Creek, McQueen Branch, and Tims Branch. The HECHMS input parameters for the Upper Three Runs, shown in Table 4, are obtained from Reference 4. The rainfall input for the HEC-HMS simulations are from Section 2. For example, Figure 13 is a HEC-HMS simulated hydrograph for the Upper Three Runs watershed in response to a total rainfall of 2.8 inches in a period of 3 hours. Figure 13 shows the runoff flow varies with time and the flow reaches a peak value of 3300 cubic feet per second (cfs) about 30 hours after the start of the rainfall. To model contaminant transport from this runoff transit accurately would require more input parameters from the user such as the rainfall starting time, and the contaminant release time relative to the rainfall starting time. To simplify the user input, it is assumed that the peak runoff flow is used in the transport calculation. This conservative assumption will result in a shorter arrival time for contaminant transport.

Figures 14 to 18 present the calculated Upper Three Runs peak flow as a function of total precipitation for rainfall duration $1,3,6,12$, and 24 hours, respectively. The equations shown in the figures are obtained by a least square curve fitting program [10] and are used in the STREAM II-V5.

Tinker Creek, McQueen Branch and Tims Branch are sub-basins of the Upper Three Runs. Therefore, the peak flows for the Tinker Creek, McQueen Branch and Tims Branch are derived from the Upper Three Runs peak flows with the assumption that the sub-basin flow is proportional to the sub-basin area.

\subsection{BEAVER DAM CREEK}

Beaver Dam Creek was an intermittent stream before SRS operation. The D-area Outfall D01 is in Beaver Dam Creek, which discharges to the Savannah River. Most of the structures in D-area have been demolished. The only active facility is the power house which will be replaced by a new facility is constructed near F-Area. The Beaver Dam Creek drainage area is 0.73 square miles which is very small. Therefore, the Beaver Dam Creek basin flow runoff was not accounted for in this revision i.e. STREAM II-V5 continues to use monthly average flows.

\subsection{FOURMILE BRANCH}

The Fourmile Branch basin has about 25.3 square miles of drainage area including much of F-, H, and C-Areas. The stream flows to the southwest into the Savannah River swamp and then into the Savannah River. The HEC-HMS input parameters for the Fourmile Branch watershed, shown in Table 4, are obtained from Reference 4. Figures 19 to 23 present the calculated Fourmile Branch peak flow as a function of total precipitation for rainfall duration 
$1,3,6,12$, and 24 hours, respectively. The equations shown in the figures are obtained by the least square curve fitting and are used in the STREAM II-V5.

\subsection{PEN BRANCH}

The Pen Branch basin drainage area is about 21.6 square miles. Pen Branch follows a path roughly parallel to Fourmile Branch until it enters the Savannah River swamp. The only significant tributary to Pen Branch is Indian Grave Branch, which flows into Pen Branch about 5 miles upstream from the swamp. Pen Branch enters the swamp about 3 miles from the Savannah River, flows directly toward the river for about 1.5 miles, and then turns and runs parallel to the river for about 5 miles before discharging into Steel Creek at about 0.5 mile from its mouth. The HEC-HMS input parameters for the Pen Branch watershed, shown in Table 4, are obtained from Reference 5. Figures 24 to 28 present the calculated Pen Branch peak flow as a function of total precipitation for rainfall duration 1, 3, 6, 12, and 24 hours, respectively. The equations shown in the figures are obtained by the least square curve fitting and are used in the STREAM II-V5.

\subsection{STEEL CREEK}

The major tributary of the Steel Creek is Meyers Branch. The L-Lake is at the upper stream of the Steel Creek, as shown in Figure 11. The outlet flow from the L-Lake is controlled by the operation of L-Lake dam. Therefore, the L-Lake outlet flow is less affected by a rainfall event. However, the response of the Steel Creek flow to rainfall events mostly results from the runoff of the Meyers Branch. The HEC-HMS input parameters for the upper stream of the Steel Creek [5] are used for the Meyers Branch sub-basin watershed runoff simulations, as shown in Table 4. Figures 29 to 33 show the calculated peak flow for the Steel Creek watershed as a function of total precipitation for rainfall duration 1, 3, 6, 12, and 24 hours, respectively. The equations shown in the figures are obtained by the least square curve fitting and are used in the STREAM II-V5.

\subsection{LOWER THREE RUNS}

PAR Pond is at the upstream of Lower Three Runs, as shown in Figure 12. The flow from PAR Pond is controlled by the PAR Pond dam. The effect of rainfall on PAR Pond outlet flow is small compared with the effect of rainfall on the runoff flow from the sub-basin downstream from the PAR Pond dam. Therefore, the runoff flow from the sub-basin downstream of the PAR Pond dam is used in this revised STREAM II code. The input parameters for the Lower Three Runs (downstream of the PAR Pond) are presented in Table 4. The basin area and the Soil Conservation Service (SCS) lag time for the Lower Three Runs sub-basin were calculated by the HEC-GeoHMS. Note that the SCS was renamed the Natural Resources Conservation Services in 1994. The remainder of the input parameters for the Lower Three Runs sub-basin were estimated based on judgment. Figures 34 to 38 present the calculated peak flow for the PAR Pond sub-basin as a function of total precipitation for rainfall duration 1, 3, 6, 12, and 24 hours, respectively. The equations shown in the figures are obtained by the least square curve fitting and are used in the STREAM II-V5. 


\subsection{SAVANNAH RIVER}

The Savannah River flow is strongly influenced by the operations of the upstream dams. The Savannah river watershed runoff is the result of both rainfall and the operations of the upstream dams. The area of the Savannah River basin is large covering 10577 square miles. Most of the rainfall events only cover parts of the basin. Therefore, the Savannah River basin flow runoff was not accounted for in this revision i.e. STREAM II-V5 continues to use monthly average flows. However, the runoff flows from the SRS sub-basins to the Savannah River were included.

\section{STREAM SEGMENT VOLUME AS A FUNCTION OF RUNOFF FLOW}

The Dynamic Estuary Model Hydrodynamics Program (DYNHYD5) [11] was used to calculate the stream cross-sections as a function of flows. DYNHYD is maintained by the Environmental Protection Agency (EPA) and is in the public domain. DYNHYD, a onedimensional hydrodynamic model, solves a system of conservation of momentum and mass equations describing the propagation of long waves through a shallow water system. The data required by DYNHYD to perform a simulation for a particular inlet flow and downstream water elevation are channel geometry, slope, and roughness.

The channel geometry, slope, and roughness for the Upper Three Runs, McQueen Branch, Tims Branch and the Savannah River were estimated from the data provided by Timothy H. Lanier of the United States Geological Survey (USGS), Columbia, South Carolina Office [12]. Similarly, these three parameters for Fourmile Branch were estimated from Reference 13, for Pen Branch and Steel Creek were estimated from Reference 14, and for the Lower Three Runs were estimated from Reference 15.

The calculated segment volume as a function of flow for the Upper Three Runs, McQueen Branch, Tims Branch, Fourmile Branch, Pen Branch, Steel Creek, Lower Three Runs, and Savannah River are presented in Figures 39 through 46, respectively. Note that a segment length of 500 meters was used for all the streams except for the Fourmile Branch. A segment length of 150 meters was used for the Fourmile Branch in order to better fit the results from 1995 dye studies and to reduce computing time [16].

\section{CODE MODIFICATIONS}

The major changes of the code were:

1. provide user a means of inputting the total rainfall and rainfall duration,

2. employ the input to calculate the stream flow based on results in Section 4, and

3. use the stream flow to adjust the stream volume based on the results in Section 5 . 
The major subroutines modified or added are described below.

Subroutine TALK_VIRTUAL was modified to allow the user to input the total rainfall in inches (or millimeters) and the rainfall period (in hours).

Subroutine BSNFLW was added to calculate watershed peak runoff flow based on the rainfall event input.

Subroutine UPT was added to update the Upper Three Runs input flows.

Subroutine RMQB was added to update the McQueen Branch input flows.

Subroutine TIMSB was added to update the Tims Branch input flows.

Subroutine FMB was added to update the Fourmile Branch input flows.

Subroutine PNB was added to update the Pen Branch input flows.

Subroutine STEEL was added to update the Steel Creek input flows.

Subroutine LTR was added to update the Lower Three Runs input flows.

Subroutine VLMCRT was revised to calculate total flow in each stream segment.

Subroutine VLMF was modified to calculate the stream segment volume based on the flow in the stream segment.

Subroutine DFADJST was added to adjust the stream segment cross-section area to account for the effect of flow variation.

Figure 47 presents the revised user graphical interface. The inputs for rainfall are shown inside the ellipse.

\section{TEST RESULTS}

Test cases were run to compare the model predicted results between STREAM II-V4 and STREAM II-V5, and examine the effects of the rainfall runoff on contaminant transport.

\subsection{STREAM II-V4 vs. STREAM II-V5}

Baseline cases were simulated by STREAM II-V4 with no rainfall. The cases simulated were one-pound hazardous chemical material released from each of the various SRS facilities. Those same cases were also simulated by STREAM II-V5. Figure 48 shows the comparison of peak concentrations predicted by STREAM II-V4 and STREAM II-V5, and 
Figure 49 shows the comparison of peak concentration arrival time. The peak concentrations and the peak concentration arrival times predicted by STREAM II-V5 are in good agreement with that predicted by STREAM II-V4, except for a few cases, as noted below.

Note that in Figures 48 and 49, each dot represents a different sampling location downstream of a release. The green dots in Figure 48 represent the simulation results for a release into the Steel Creek, while the blue dots represent the simulation results for a release into the Lower Three Runs. Similarly, in Figure 49, the blue dots represent the simulation results for a release into the Lower Three Runs, while the red dots represent the simulation results for a release into the Pen Branch. In STREAM II-V5, the segment volumes were varied as a function of flow. Likewise, for STREAM II-V4, the segment volumes were also varied as a function of flow except for the Pen Branch, Steel Creek and Lower Three Runs. In STREAM II-V4, the segment volumes for these three streams were kept constant and were independent of the stream flow rate. This was assumed due to relatively small variations in flow rate because rainfall was not accounted for in the model (STREAM II-V4). Therefore, segment volumes for Pen Branch, Steel Creek and Lower Three Runs used in STREAM IIV4 are different from that used in STREAM II-V5. As a result, the predictions of the peak concentration and peak concentration arrival time are not in good agreement between these two versions, as shown in Figures 48 and 49, respectively. For example, the difference in the predicted peak concentration between these two versions is up to $35.7 \%$, and the difference in the predicted peak concentration arrival time is up to $23.7 \%$ for the release to the Lower Three Runs. Table 5 shows the model comparison of peak concentration and peak concentration arrival time at various downstream locations between STREAM II-V4 and STREAM II-V5.

\subsection{RAINFALL EFFECTS}

The baseline cases (one pound of hazardous chemical material was released from all of the various SRS facilities) as described in Section 7.1 were re-run by STREAM II-V5 to include rainfall effects. Two weather conditions were simulated. One weather condition assumed a total rainfall of 1 inch in 3 hours while the other assumed a total rainfall of 10 inches in 24 hours.

Rainfall runoff increases stream flow. Increased stream flow in turn results in increases in flow velocity and the stream volume (cross-section). The concentration in the stream is influenced by the flow velocity and stream volume. Concentration decreases as stream volume increases. The time for contaminant traveling to a downstream location decreases as flow velocity increases. On the other hand, the extent of contaminant dispersion decreases (concentration increases) as traveling time decreases. This is because there is less time available for dispersion. These two competing factors determine the final peak concentration in the stream. This phenomenon is observed in Figures 50 and 51.

The runoff flow for the case of total rainfall of 10 inches in 24 hours is larger than the case of total rainfall of 1 inch in 3 hours. For example, the Upper Three Runs runoff flow is 10.5 $\mathrm{m}^{3} / \mathrm{s}$ for the case of total rainfall of 1 inch in 3 hours (Fig. 15), and the runoff flow increases to $200.8 \mathrm{~m}^{3} / \mathrm{s}$ for the case of total rainfall of 10 inches in 24 hours (Fig. 18). Figure 50 shows 
the comparison of peak concentration arrival time at downstream locations. The X-axis represents the peak concentration arrival time for the case of no rainfall. The Y-axis represents the corresponding peak concentration arrival time with rainfall effects. The red circles represent the case of total rainfall of 1 inch in 3 hours and the black inverse triangles represent the case of total rainfall of 10 inches in 24 hours. The peak concentration arrival time for the case of total rainfall of 10 inches in 24 hours is less than the case of total rainfall of 1 inch in 3 hours, while the peak concentration arrival time for the case of total rainfall of 1 inch in 3 hours is less than the case of no rainfall, as shown in Figure 50.

Figure 51 presents the comparison of peak concentrations at sampling locations. The X-axis represents the peak concentration for the case of no rainfall. The Y-axis represents the corresponding peak concentration with rainfall effects. The red circles represent the case of total rainfall of 1 inch in 3 hours and the black inverse triangles represent the case of total rainfall of 10 inches in 24 hours. The data in the upper right corner of Figure 51 represent sampling locations near the release points. The peak concentration travel time to the locations near the release location is short. For a short traveling time (less than 600 minutes or roughly one-half day), the influence of the dispersion on the concentration is less important than the influence of the flow volume increase. Therefore, for the sampling location near the release location, the peak concentration decreases as runoff flow increases, as shown in the upper right corner of Figure 51.

The data in the lower left corner of Figure 51 represent peak concentrations at sampling locations far away from the release point. The travel time to those downstream sampling locations are large. However, the travel time for the rainfall cases are much shorter than that of the no rainfall case (Figure 50) due to rainfall runoff. The difference in the travel time can vary up to several thousand minutes ( $\sim 2$ to 3 days). The concentrations for the rainfall cases are higher since less time is available for dispersion. The flow volumes for the rainfall cases are larger than the no rainfall case, which results in lower concentration for the rainfall case. For those downstream sampling locations, the influence of the dispersion on the peak concentration could override the influence of the flow volume increase. Therefore, the peak concentration at those downstream sampling locations is actually higher for the cases of higher runoff flow (black triangles), as shown in the lower left corner of Figure 51. Table 6 shows the effects of rainfall on contaminant transport at downstream locations.

\section{CONCLUSIONS}

STREAM II-V4 is an aqueous transport module of the Savannah River Site emergency response Weather INformation Display (WIND) system. The input flows for the STREAM II-V4 are derived by averaging the historical daily mean flow records by month. The stream flow for the STREAM II-V4 is fixed and the flow only varies with the month in which the releases are taking place. Therefore, the effects of flow surge due to a severe storm are not accounted for by the STREAM II-V4. The STREAM II-V4 was revised to account for the effects of a storm event. The steps used in this revision are: 1) generate design rainfall hyetographs as a function of total rainfall in inches and rainfall duration in hours, 2) generate watershed runoff flow based on the rainfall hyetographs from step 1, 3) calculate the variation of stream cross section as a function of flow from step 2, and 4) implement the 
results from steps 2 and 3 into the STREAM II model. The revised model, STREAM II-V5, has an option to account for the effects of rainfall on contaminant transport through the SRS streams and the Savannah River. The effect of rainfall has been shown to impact stream concentration in two competing ways.

This study shows that incorporating rainfall runoff in STREAM II-V5 increases the stream flow. Increased stream flow in turn results in increases in flow velocity and the stream volume (cross-section). The stream concentration is influenced by the flow velocity and stream volume. This concentration decreases as stream volume increases, and the time for contaminant travel to a downstream location decreases as the flow velocity increases. On the other hand, the extent of contaminant dispersion decreases (i.e. concentration increases) as the travel time decreases. This is due to less time being available for dispersion. These two competing factors determine the final peak concentration in the stream. Thus, for the locations near a release point, the effect of the stream volume increase overrides the effect of contaminant travel time. Consequently, the peak concentration for a case with rainfall is lower than a case with no rainfall. Conversely, for locations far away from a release point, the effect of contaminant travel time overrides the effect of the stream volume increase. As a result, the peak concentration for the rainfall case is higher than that of the non-rainfall case.

Note that the loss rate used in the HEC-HMS model determines the amount of infiltration which depends on the soil physical and chemical properties, and initial moisture content. The loss rates used in Section 4 were derived by calibrating the MEC-HMS model with limited measured precipitation and stream flow records, as described in References 4 and 5. The rainfall used in References 4 and 5 occurred in January, March and May. The soil moisture content for those months might be higher than the soil moisture content in the summer months. Therefore, the peak runoff flow derived in Section 4 could be higher than the actual runoff peak flow in the summer months. The recommendation for future improvement is to derive the loss rates using the measured historical records by month.

\section{ACKNOWLEDGEMENT}

The graphical user interface (GUI) of the STREAM II-V5 was revised by G. L. Snyder. 


\section{REFERENCES}

1. Chen, Kuo-Fu and Gary L. Snyder, "STREAM II-V4 Revision for STREAM II-V3 to Allow Mouse-Driven Selection of Release Location from a Graphical User Interface (U),” WSRC-TR-2002-00470, Savannah River Site, October 9, 2002.

2. Hunter, C. H., "Weather Information and Display (WIND) System User's Manual (U)," WSRC-TM-90-14, Savannah River Site, 1990.

3. Ambrose, Robert B., Tim A. Wool, James L. Martin, “The Water Quality Analysis Simulation Program, WASP5, Part A. Model Documentation; Part B: Input Dataset,” Environmental Research Laboratory, Office of Research and Development, U.S. Environmental Protection Agency, Athens, Georgia, September 20, 1993.

4. Chen, Kuo-Fu, "Flood Hazard Recurrence Frequencies for C-, F-, E-, S-, H-, Y-, and ZAreas (U),” WSRC-TR-99-00369, Savannah River Site, September 30, 1999.

5. Chen, Kuo-Fu, "Flood Hazard Recurrence Frequencies for A-, K- and L-Areas, and Revised Frequencies for C-, F-, E-, S-, H-, Y-, and Z-Areas (U),” WSRC-TR-2000-00206, Savannah River Site, June 30, 2000.

6. “HEC-GeoHMS Geospatial Hydrologic Modeling Extension User Manual,” Version 1.1, US Army Corps of Engineers, Hydrologic Engineering Center, Davis, California, December 2003.

7. http://ned.usgs.gov/www,usgs.gov.

8. “ArcView GIS: The Geographic Information System for Everyone,” Environmental System Research Institute, Inc., 1996.

9. “HEC-HMS: Hydrologic Modeling System, User's Manual,” Version 1.0, US Army Corps of Engineers, Hydrologic Engineering Center, Davis, California, Mrach, 1998.

10. Hyde, David, "DPlot: Plotting Software for Scientists and Engineers,” http://www.dplot.com.

11. Ambrose, Robert B. Jr., Tim A. Wool, and James L. Martin, “The Dynamic Estuary Model Hydrodynamics Program, DYNHYD5 Model Documentation and User Manual,” Environmental Research Laboratory, Athens, Georgia, September 8, 1993.

12. Lanier, T. H., "Determination of the 100-Year Flood Plain on Upper Three Runs and Selected Tributaries, and the Savannah River at the Savannah River Site, South Carolina, 1995,” USGS Water-Resources Investigation Report 96-4014, 1996. 
13. Lanier, T. H., "Determination of the 100-Year Flood Plain on Fourmile Branch at the Savannah River Site, South Carolina, 1996,” USGS Water-Resources Investigation Report 96-4271, 1997.

14. Lanier, T.H., "Determination of the 100-Year Flood Plain on Pen Branch, Steel Creek, and their Selected Tributaries, Savannah River Site, South Carolina, 1996,” USGS WaterResources Investigations Report 97-4090, 1997.

15. "Sediment Erosion and Transport Studies PAR Pond and Lower Three Runs, Savannah River Site,” BSRI, October 1991.

16. Chen, Kuo-Fu, "STREAM2 for SRS Aqueous Release Emergency Response (U)," WSRC-TR-98-00234,Savannah River Site, June 1998. 
SRNL-STI-2010-00116

Table 1. Six-Hour Storm Rainfall Distribution as a Function of Return Period

\begin{tabular}{|c|c|c|c|c|c|c|c|}
\hline \multirow{2}{*}{$\begin{array}{l}\text { Return } \\
\text { Period }\end{array}$} & Hour 1 & Hour 2 & Hour 3 & Hour 4 & Hour 5 & Hour 6 & Accumulation \\
\cline { 2 - 7 } & in & in & in & in & in & in & in \\
\hline 50-year & 0.13 & 0.33 & 1.22 & 0.71 & 0.20 & 0.07 & 2.65 \\
\hline 100-year & 0.15 & 0.37 & 1.39 & 0.81 & 0.22 & 0.08 & 3.02 \\
\hline 500-year & 0.19 & 0.48 & 1.80 & 1.05 & 0.29 & 0.11 & 3.92 \\
\hline
\end{tabular}


Table 2. 24-Hour Storm Rainfall Distributions as a Function of Return Period

\begin{tabular}{|l|c|c|c|}
\hline \multirow{2}{*}{} & \multicolumn{3}{|c|}{ Return Period } \\
\cline { 2 - 4 } & 50-year & 100 -year & 500-year \\
\cline { 2 - 4 } & in & in & In \\
\hline Hour 1 & 0.035 & 0.039 & 0.052 \\
\hline Hour 2 & 0.062 & 0.070 & 0.093 \\
\hline Hour 3 & 0.083 & 0.094 & 0.124 \\
\hline Hour 4 & 0.242 & 0.273 & 0.361 \\
\hline Hour 5 & 0.393 & 0.445 & 0.587 \\
\hline Hour 6 & 0.524 & 0.593 & 0.783 \\
\hline Hour 7 & 0.725 & 0.819 & 1.082 \\
\hline Hour 8 & 1.863 & 2.106 & 2.781 \\
\hline Hour 9 & 1.139 & 1.287 & 1.700 \\
\hline Hour 10 & 0.628 & 0.710 & 0.937 \\
\hline Hour 11 & 0.414 & 0.468 & 0.618 \\
\hline Hour 12 & 0.338 & 0.382 & 0.505 \\
\hline Hour 13 & 0.117 & 0.133 & 0.175 \\
\hline Hour 14 & 0.076 & 0.086 & 0.113 \\
\hline Hour 15 & 0.048 & 0.055 & 0.072 \\
\hline Hour 16 & 0.035 & 0.039 & 0.052 \\
\hline Hour 17 & 0.035 & 0.039 & 0.052 \\
\hline Hour 18 & 0.028 & 0.031 & 0.041 \\
\hline Hour 19 & 0.028 & 0.031 & 0.041 \\
\hline Hour 20 & 0.021 & 0.023 & 0.031 \\
\hline Hour 21 & 0.021 & 0.023 & 0.031 \\
\hline Hour 22 & 0.021 & 0.023 & 0.031 \\
\hline Hour 23 & 0.014 & 0.016 & 0.021 \\
\hline Hour 24 & 0.014 & 0.016 & 0.021 \\
\hline Accumulation & 6.900 & 7.800 & 10.300 \\
\hline
\end{tabular}


SRNL-STI-2010-00116

Table 3 Design Rainfall Events for STREAM II-V5

\begin{tabular}{|c|c|c|c|c|c|c|c|}
\hline $\begin{array}{c}\text { Rainfall Duration } \\
\text { (hour) }\end{array}$ & \multicolumn{7}{|c|}{$\begin{array}{c}\text { Total Rainfall } \\
\text { (inches) }\end{array}$} \\
\hline 1 & 0.5 & 1.0 & 2.0 & 3.0 & & & \\
\hline 3 & 0.3 & 0.6 & 1.2 & 1.8 & 2.4 & 3.0 & \\
\hline 6 & 0.6 & 1.2 & 1.8 & 2.4 & 3.0 & 3.6 & 4.8 \\
\hline 12 & 1.2 & 2.4 & 3.6 & 4.8 & 6.0 & 7.2 & \\
\hline 24 & 2.4 & 4.8 & 7.2 & 9.6 & 12.0 & & \\
\hline
\end{tabular}


Table 4. HEC-HMS Input Parameters

\begin{tabular}{|c|c|c|c|c|c|}
\hline & $\begin{array}{l}\text { Upper Three } \\
\text { Runs }\end{array}$ & $\begin{array}{l}\text { Fourmile } \\
\text { Branch }\end{array}$ & Pen Branch & $\begin{array}{c}\text { Steel } \\
\text { Creek* }\end{array}$ & $\begin{array}{c}\text { Lower } \\
\text { Three Runs }\end{array}$ \\
\hline Basin Area $\left(\mathrm{mi}^{2}\right)$ & 204.5 & 25.3 & 21.6 & 19.2 & 123.5 \\
\hline \multicolumn{6}{|l|}{ Loss Rate: } \\
\hline Method & initial/const. & initial/const. & initial/const. & initial/const & initial/const \\
\hline Initial Loss (in) & 0.0 & 0.0 & 0.0 & 0.0 & 0.0 \\
\hline $\begin{array}{l}\text { Constant Rate } \\
\text { (in/hr) }\end{array}$ & 0.715 & 0.5 & 0.45 & 0.89 & 0.45 \\
\hline $\begin{array}{c}\text { Imperviousness } \\
(\%)\end{array}$ & 2 & 3 & 2 & 0.5 & 1.0 \\
\hline \multicolumn{6}{|l|}{ Transform: } \\
\hline Method & SCS & SCS & SCS & SCS & SCS \\
\hline SCS lag (minute) & 2000 & 750 & 600 & 250 & 796 \\
\hline \multicolumn{6}{|l|}{ Base Flow: } \\
\hline Method & recession & recession & recession & recession & recession \\
\hline Initial Flow (ft3/s) & 190 & 27 & 18 & 2 & 2 \\
\hline $\begin{array}{c}\text { Recession } \\
\text { Constant }\end{array}$ & 0.965 & 1.0 & 0.80 & 0.9 & 0.9 \\
\hline $\begin{array}{c}\text { Thresholds flow } \\
\text { (ft3/s) }\end{array}$ & 200 & 39 & 60 & 3 & 3 \\
\hline
\end{tabular}

*Meyers Branch 
Table 5 Model Comparison between STREAM II-V4 and STREAM II-V5

\begin{tabular}{|c|c|c|c|c|c|c|c|}
\hline \multirow{3}{*}{$\begin{array}{l}\text { Release } \\
\text { Location }\end{array}$} & \multirow[t]{3}{*}{ Monitor Locations } & \multicolumn{3}{|c|}{ Concentration } & \multicolumn{3}{|c|}{ Travel time } \\
\hline & & V4 & V5 & Diff. & V4 & V5 & Diff. \\
\hline & & (lb/gal) & (lb/gal) & $(\%)$ & (min) & $(\min )$ & $(\%)$ \\
\hline \multirow{5}{*}{$\begin{array}{l}\text { Release at Road } \\
\text { A (Fourmile } \\
\text { Creek) }\end{array}$} & SAVANNAH RIVER: & $8.10 \mathrm{E}-10$ & 7.61E-10 & -6.07 & 1152.00 & 1152.00 & 0.00 \\
\hline & US HIGHWAY 301: & $5.90 \mathrm{E}-10$ & $5.64 \mathrm{E}-10$ & -4.49 & 2390.40 & 2419.20 & 1.20 \\
\hline & STATE HIGHWAY 119: & 4.31E-10 & 4.16E-10 & -3.51 & 4521.60 & 4550.40 & 0.64 \\
\hline & BEAUFORT-JASPER: & 4.05E-10 & $3.94 \mathrm{E}-10$ & -2.80 & 5356.80 & 5385.60 & 0.54 \\
\hline & SAV. WATER PLANT: & $3.97 \mathrm{E}-10$ & $3.82 \mathrm{E}-10$ & -3.81 & 5760.00 & 5731.20 & -0.50 \\
\hline \multirow{6}{*}{$\begin{array}{l}\text { Release from A- } \\
\text { Area to Tims } \\
\text { Branch }\end{array}$} & ROAD A: & 1.79E-08 & $1.80 \mathrm{E}-08$ & 0.42 & 1152.00 & 1137.60 & -1.25 \\
\hline & SAVANNAH RIVER: & 5.03E-10 & $5.07 \mathrm{E}-10$ & 0.75 & 1526.40 & 1526.40 & 0.00 \\
\hline & US HIGHWAY 301: & 4.05E-10 & 4.05E-10 & 0.00 & 2966.40 & 2966.40 & 0.00 \\
\hline & STATE HIGHWAY 119: & 3.32E-10 & 3.32E-10 & 0.00 & 4982.40 & 4982.40 & 0.00 \\
\hline & BEAUFORT-JASPER: & $3.19 \mathrm{E}-10$ & $3.18 \mathrm{E}-10$ & -0.24 & 5788.80 & 5760.00 & -0.50 \\
\hline & SAV. WATER PLANT: & 3.13E-10 & $3.12 \mathrm{E}-10$ & -0.36 & 6134.40 & 6105.60 & -0.47 \\
\hline \multirow{5}{*}{$\begin{array}{l}\text { Release at Road } \\
\text { A (Steel Creek) }\end{array}$} & SAVANNAH RIVER: & $2.30 \mathrm{E}-10$ & $1.78 \mathrm{E}-10$ & -22.41 & 956.40 & 1085.40 & 13.49 \\
\hline & US HIGHWAY 301: & $2.07 \mathrm{E}-10$ & $1.61 \mathrm{E}-10$ & -22.30 & 1804.20 & 1905.60 & 5.62 \\
\hline & STATE HIGHWAY 119: & $1.90 \mathrm{E}-10$ & $1.48 \mathrm{E}-10$ & -21.76 & 3831.60 & 3960.60 & 3.37 \\
\hline & BEAUFORT-JASPER: & $1.88 \mathrm{E}-10$ & $1.48 \mathrm{E}-10$ & -21.68 & 4642.80 & 4744.20 & 2.18 \\
\hline & SAV. WATER PLANT: & $1.88 \mathrm{E}-10$ & $1.48 \mathrm{E}-10$ & -21.53 & 4983.60 & 5112.60 & 2.59 \\
\hline \multirow{5}{*}{$\begin{array}{l}\text { Release to D-Area } \\
\text { Outfall }\end{array}$} & SAVANNAH RIVER: & $2.08 \mathrm{E}-09$ & 2.02E-09 & -2.91 & 216.00 & 216.00 & 0.00 \\
\hline & US HIGHWAY 301: & 8.74E-10 & 8.59E-10 & -1.73 & 1540.80 & 1540.80 & 0.00 \\
\hline & STATE HIGHWAY 119: & $5.49 \mathrm{E}-10$ & $5.41 \mathrm{E}-10$ & -1.38 & 3672.00 & 3672.00 & 0.00 \\
\hline & BEAUFORT-JASPER: & $5.00 \mathrm{E}-10$ & 4.92E-10 & -1.52 & 4507.20 & 4507.20 & 0.00 \\
\hline & SAV. WATER PLANT: & $4.81 \mathrm{E}-10$ & 4.77E-10 & -0.79 & 4881.60 & 4881.60 & 0.00 \\
\hline \multirow[t]{6}{*}{ Release at F-Area } & ROAD A: & $1.68 \mathrm{E}-07$ & 1.62E-07 & -3.39 & 1267.20 & 1296.00 & 2.27 \\
\hline & SAVANNAH RIVER: & $5.60 \mathrm{E}-10$ & 5.34E-10 & -4.73 & 2419.20 & 2476.80 & 2.38 \\
\hline & US HIGHWAY 301: & 4.54E-10 & 4.35E-10 & -4.17 & 3686.40 & 3744.00 & 1.56 \\
\hline & STATE HIGHWAY 119: & 3.59E-10 & $3.46 \mathrm{E}-10$ & -3.59 & 5817.60 & 5875.20 & 0.99 \\
\hline & BEAUFORT-JASPER: & $3.44 \mathrm{E}-10$ & 3.32E-10 & -3.41 & 6652.80 & 6710.40 & 0.87 \\
\hline & SAV. WATER PLANT: & $3.38 \mathrm{E}-10$ & $3.27 \mathrm{E}-10$ & -3.36 & 7027.20 & 7084.80 & 0.82 \\
\hline \multirow{6}{*}{$\begin{array}{l}\text { Release at Road C } \\
\text { (flowing streams) }\end{array}$} & ROAD A: & $2.25 \mathrm{E}-08$ & $2.25 \mathrm{E}-08$ & 0.17 & 662.40 & 662.40 & 0.00 \\
\hline & SAVANNAH RIVER: & $5.90 \mathrm{E}-10$ & $5.90 \mathrm{E}-10$ & 0.00 & 1051.20 & 1051.20 & 0.00 \\
\hline & US HIGHWAY 301: & $4.54 \mathrm{E}-10$ & 4.54E-10 & 0.00 & 2476.80 & 2476.80 & 0.00 \\
\hline & STATE HIGHWAY 119: & $3.62 \mathrm{E}-10$ & $3.61 \mathrm{E}-10$ & -0.21 & 4521.60 & 4492.80 & -0.64 \\
\hline & BEAUFORT-JASPER: & $3.45 \mathrm{E}-10$ & $3.44 \mathrm{E}-10$ & -0.33 & 5299.20 & 5299.20 & 0.00 \\
\hline & SAV. WATER PLANT: & $3.38 \mathrm{E}-10$ & 3.37E-10 & -0.45 & 5644.80 & 5644.80 & 0.00 \\
\hline \multirow{6}{*}{$\begin{array}{l}\text { Release at } \\
\text { Highway } 278 \text { to } \\
\text { Upper Three Runs }\end{array}$} & ROAD A: & $1.57 \mathrm{E}-08$ & $1.57 \mathrm{E}-08$ & 0.24 & 1512.00 & 1512.00 & 0.00 \\
\hline & SAVANNAH RIVER: & 4.58E-10 & $4.58 \mathrm{E}-10$ & 0.00 & 1915.20 & 1900.80 & -0.75 \\
\hline & US HIGHWAY 301: & $3.74 \mathrm{E}-10$ & $3.74 \mathrm{E}-10$ & 0.10 & 3340.80 & 3340.80 & 0.00 \\
\hline & STATE HIGHWAY 119: & $3.12 \mathrm{E}-10$ & $3.12 \mathrm{E}-10$ & -0.12 & 5356.80 & 5356.80 & 0.00 \\
\hline & BEAUFORT-JASPER: & $3.01 \mathrm{E}-10$ & $3.00 \mathrm{E}-10$ & -0.25 & 6163.20 & 6163.20 & 0.00 \\
\hline & SAV. WATER PLANT: & $2.96 \mathrm{E}-10$ & $2.96 \mathrm{E}-10$ & -0.26 & 6508.80 & 6508.80 & 0.00 \\
\hline \multirow[t]{6}{*}{ Release at H-Area } & ROAD A: & $1.41 \mathrm{E}-07$ & $1.37 \mathrm{E}-07$ & -3.22 & 1612.80 & 1670.40 & 3.57 \\
\hline & SAVANNAH RIVER: & $4.81 \mathrm{E}-10$ & 4.54E-10 & -5.51 & 2736.00 & 2793.60 & 2.11 \\
\hline & US HIGHWAY 301: & 4.13E-10 & $3.94 \mathrm{E}-10$ & -4.59 & 3945.60 & 4003.20 & 1.46 \\
\hline & STATE HIGHWAY 119: & $3.36 \mathrm{E}-10$ & $3.24 \mathrm{E}-10$ & -3.71 & 6048.00 & 6105.60 & 0.95 \\
\hline & BEAUFORT-JASPER: & $3.24 \mathrm{E}-10$ & $3.12 \mathrm{E}-10$ & -3.62 & 6883.20 & 6940.80 & 0.84 \\
\hline & SAV. WATER PLANT: & $3.18 \mathrm{E}-10$ & $3.07 \mathrm{E}-10$ & -3.45 & 7228.80 & 7286.40 & 0.80 \\
\hline
\end{tabular}


SRNL-STI-2010-00116

\begin{tabular}{|c|c|c|c|c|c|c|c|}
\hline \multirow{6}{*}{$\begin{array}{l}\text { Release at K-Area } \\
\text { Outfall }\end{array}$} & ROAD A: & $3.16 \mathrm{E}-07$ & 3.07E-07 & -2.76 & 129.60 & 129.60 & 0.00 \\
\hline & SAVANNAH RIVER: & $7.49 \mathrm{E}-11$ & 7.23E-11 & -3.53 & 6769.20 & 7129.20 & 5.32 \\
\hline & US HIGHWAY 301: & $6.81 \mathrm{E}-11$ & 6.59E-11 & -3.33 & 7777.20 & 8065.20 & 3.70 \\
\hline & STATE HIGHWAY 119: & $6.28 \mathrm{E}-11$ & 6.09E-11 & -3.01 & 9649.20 & 10081.20 & 4.48 \\
\hline & BEAUFORT-JASPER: & $6.28 \mathrm{E}-11$ & $6.06 \mathrm{E}-11$ & -3.61 & 10513.20 & 10801.20 & 2.74 \\
\hline & SAV. WATER PLANT: & $6.28 \mathrm{E}-11$ & $6.06 \mathrm{E}-11$ & -3.61 & 10945.20 & 11232.60 & 2.63 \\
\hline \multirow{4}{*}{$\begin{array}{l}\text { Release to the } \\
\text { Mouth of } \\
\text { Fourmile Branch }\end{array}$} & US HIGHWAY 301: & $9.46 \mathrm{E}-10$ & $9.35 \mathrm{E}-10$ & -1.20 & 1209.60 & 1209.60 & 0.00 \\
\hline & STATE HIGHWAY 119: & $5.49 \mathrm{E}-10$ & $5.45 \mathrm{E}-10$ & -0.69 & 3225.60 & 3225.60 & 0.00 \\
\hline & BEAUFORT-JASPER: & 4.96E-10 & $4.92 \mathrm{E}-10$ & -0.76 & 4032.00 & 4032.00 & 0.00 \\
\hline & SAV. WATER PLANT: & $4.77 \mathrm{E}-10$ & $4.73 \mathrm{E}-10$ & -0.79 & 4377.60 & 4377.60 & 0.00 \\
\hline \multirow{4}{*}{$\begin{array}{l}\text { Release to the } \\
\text { Mouth of Beaver } \\
\text { Dam Creek }\end{array}$} & US HIGHWAY 301: & $9.80 \mathrm{E}-10$ & $9.77 \mathrm{E}-10$ & -0.39 & 1353.60 & 1353.60 & 0.00 \\
\hline & STATE HIGHWAY 119: & $5.49 \mathrm{E}-10$ & $5.45 \mathrm{E}-10$ & -0.69 & 3484.80 & 3470.40 & -0.41 \\
\hline & BEAUFORT-JASPER: & 4.96E-10 & $4.96 \mathrm{E}-10$ & 0.00 & 4305.60 & 4305.60 & 0.00 \\
\hline & SAV. WATER PLANT: & $4.81 \mathrm{E}-10$ & $4.77 \mathrm{E}-10$ & -0.79 & 4680.00 & 4665.60 & -0.31 \\
\hline \multirow{4}{*}{$\begin{array}{l}\text { Release to the } \\
\text { Mouth of Lower } \\
\text { Three Runs }\end{array}$} & US HIGHWAY 301: & $1.90 \mathrm{E}-09$ & 2.12E-09 & 11.55 & 439.80 & 421.80 & -4.09 \\
\hline & STATE HIGHWAY 119: & $9.80 \mathrm{E}-10$ & $1.00 \mathrm{E}-09$ & 2.31 & 2467.80 & 2449.20 & -0.75 \\
\hline & BEAUFORT-JASPER: & 8.86E-10 & 8.97E-10 & 1.28 & 3269.40 & 3260.40 & -0.28 \\
\hline & SAV. WATER PLANT: & $8.52 \mathrm{E}-10$ & 8.59E-10 & 0.89 & 3619.80 & 3601.20 & -0.51 \\
\hline \multirow{6}{*}{$\begin{array}{l}\text { Release from H- } \\
\text { Area to McQueen } \\
\text { Branch }\end{array}$} & ROAD A: & $1.46 \mathrm{E}-08$ & $1.46 \mathrm{E}-08$ & 0.26 & 1629.00 & 1647.60 & 1.14 \\
\hline & SAVANNAH RIVER: & $4.39 \mathrm{E}-10$ & 4.39E-10 & 0.00 & 2034.60 & 2016.00 & -0.91 \\
\hline & US HIGHWAY 301: & $3.82 \mathrm{E}-10$ & $3.82 \mathrm{E}-10$ & 0.00 & 3463.20 & 3435.00 & -0.81 \\
\hline & STATE HIGHWAY 119: & $3.43 \mathrm{E}-10$ & $3.42 \mathrm{E}-10$ & -0.22 & 5472.00 & 5472.00 & 0.00 \\
\hline & BEAUFORT-JASPER: & $3.38 \mathrm{E}-10$ & 3.37E-10 & -0.45 & 6283.20 & 6283.20 & 0.00 \\
\hline & SAV. WATER PLANT: & $3.36 \mathrm{E}-10$ & $3.35 \mathrm{E}-10$ & -0.34 & 6624.00 & 6624.00 & 0.00 \\
\hline \multirow{4}{*}{$\begin{array}{l}\text { Release to the } \\
\text { Mouth of Upper } \\
\text { Three Runs }\end{array}$} & US HIGHWAY 301: & 8.33E-10 & $8.29 \mathrm{E}-10$ & -0.45 & 1468.80 & 1468.80 & 0.00 \\
\hline & STATE HIGHWAY 119: & $5.22 \mathrm{E}-10$ & $5.15 \mathrm{E}-10$ & -1.45 & 3484.80 & 3456.00 & -0.83 \\
\hline & BEAUFORT-JASPER: & $4.73 \mathrm{E}-10$ & 4.69E-10 & -0.80 & 4262.40 & 4262.40 & 0.00 \\
\hline & SAV. WATER PLANT: & $4.58 \mathrm{E}-10$ & $4.50 \mathrm{E}-10$ & -1.65 & 4636.80 & 4608.00 & -0.62 \\
\hline \multirow{4}{*}{$\begin{array}{l}\text { Release to the } \\
\text { Mouth of Steel } \\
\text { Creek-Pen Branch }\end{array}$} & US HIGHWAY 301: & $1.31 \mathrm{E}-09$ & $1.27 \mathrm{E}-09$ & -2.89 & 956.40 & 956.40 & 0.00 \\
\hline & STATE HIGHWAY 119: & $8.14 \mathrm{E}-10$ & $7.91 \mathrm{E}-10$ & -2.79 & 3085.20 & 3075.60 & -0.31 \\
\hline & BEAUFORT-JASPER: & 7.53E-10 & 7.31E-10 & -3.02 & 3924.00 & 3924.00 & 0.00 \\
\hline & SAV. WATER PLANT: & 7.31E-10 & 7.12E-10 & -2.59 & 4283.40 & 4283.40 & 0.00 \\
\hline \multirow{5}{*}{$\begin{array}{l}\text { Release at PAR } \\
\text { Pond Dam }\end{array}$} & SAVANNAH RIVER: & 2.65E-10 & $3.60 \mathrm{E}-10$ & 35.72 & 3850.20 & 2937.60 & -23.70 \\
\hline & US HIGHWAY 301: & $2.40 \mathrm{E}-10$ & $3.24 \mathrm{E}-10$ & 35.23 & 4227.60 & 3315.60 & -21.57 \\
\hline & STATE HIGHWAY 119: & $2.19 \mathrm{E}-10$ & $2.92 \mathrm{E}-10$ & 33.16 & 6255.60 & 5343.00 & -14.59 \\
\hline & BEAUFORT-JASPER: & $2.18 \mathrm{E}-10$ & $2.89 \mathrm{E}-10$ & 32.63 & 7075.80 & 6154.20 & -13.02 \\
\hline & SAV. WATER PLANT: & $2.17 \mathrm{E}-10$ & $2.88 \mathrm{E}-10$ & 32.40 & 7407.60 & 6495.00 & -12.32 \\
\hline \multirow{4}{*}{$\begin{array}{l}\text { Release to S. } \\
\text { River at } 6 \text { miles } \\
\text { downstream from } \\
\text { the Lock \& Dam }\end{array}$} & US HIGHWAY 301: & $6.85 \mathrm{E}-10$ & $6.78 \mathrm{E}-10$ & -1.10 & 2390.40 & 2361.60 & -1.20 \\
\hline & STATE HIGHWAY 119: & 4.73E-10 & 4.73E-10 & 0.00 & 4406.40 & 4406.40 & 0.00 \\
\hline & BEAUFORT-JASPER: & 4.39E-10 & 4.35E-10 & -0.86 & 5212.80 & 5212.80 & 0.00 \\
\hline & SAV. WATER PLANT: & 4.24E-10 & 4.24E-10 & 0.00 & 5558.40 & 5558.40 & 0.00 \\
\hline \multirow{5}{*}{$\begin{array}{l}\text { Release at Road } \\
\text { A (Upper Three } \\
\text { Runs) }\end{array}$} & SAVANNAH RIVER: & 9.65E-10 & 9.65E-10 & 0.00 & 388.80 & 388.80 & 0.00 \\
\hline & US HIGHWAY 301: & $6.13 \mathrm{E}-10$ & $6.13 \mathrm{E}-10$ & 0.00 & 1843.20 & 1843.20 & 0.00 \\
\hline & STATE HIGHWAY 119: & 4.43E-10 & 4.39E-10 & -0.86 & 3859.20 & 3830.40 & -0.75 \\
\hline & BEAUFORT-JASPER: & 4.13E-10 & 4.09E-10 & -0.92 & 4636.80 & 4636.80 & 0.00 \\
\hline & SAV. WATER PLANT: & $4.01 \mathrm{E}-10$ & 3.97E-10 & -0.94 & 5011.20 & 4982.40 & -0.57 \\
\hline
\end{tabular}


Table 6. Effects of Rainfall on Contaminant Transport

\begin{tabular}{|c|c|c|c|c|c|c|c|c|c|c|c|}
\hline \multirow{3}{*}{$\begin{array}{c}\text { Release } \\
\text { Location }\end{array}$} & \multirow[t]{3}{*}{ Monitor Location } & \multicolumn{5}{|c|}{ Concentration } & \multicolumn{5}{|c|}{ travel time } \\
\hline & & \multirow{2}{*}{$\begin{array}{c}\text { No Rain } \\
\text { (lb/gal) }\end{array}$} & \multicolumn{2}{|c|}{1 ” in $3 \mathrm{hr}$} & \multicolumn{2}{|c|}{$10 ”$ in $24 \mathrm{hr}$} & \multirow{2}{*}{$\frac{\text { No Rain }}{\text { (min) }}$} & \multicolumn{2}{|c|}{1 ” in $3 \mathrm{hr}$} & \multicolumn{2}{|c|}{10 ” in $24 \mathrm{hr}$} \\
\hline & & & (lb/gal) & (\% Diff) & (lb/gal) & (\% Diff) & & (min) & (\% Diff) & $(\min )$ & (\% Diff) \\
\hline \multirow{5}{*}{$\begin{array}{l}\text { Release at Road } \\
\text { A (Fourmile } \\
\text { Creek) }\end{array}$} & SAVANNAH RIVER: & $7.61 \mathrm{E}-10$ & $2.22 \mathrm{E}-09$ & 191.54 & 3.29E-09 & 332.84 & 1152 & 490 & -57.50 & 173 & -85.00 \\
\hline & US HIGHWAY 301: & $5.64 \mathrm{E}-10$ & $9.01 \mathrm{E}-10$ & 59.73 & $6.70 \mathrm{E}-10$ & 18.79 & 2419 & 1728 & -28.57 & 1181 & -51.19 \\
\hline & STATE HIGHWAY 119: & $4.16 \mathrm{E}-10$ & $5.41 \mathrm{E}-10$ & 30.00 & $3.90 \mathrm{E}-10$ & -6.36 & 4550 & 3830 & -15.82 & 2938 & -35.44 \\
\hline & BEAUFORT-JASPER: & $3.94 \mathrm{E}-10$ & $4.92 \mathrm{E}-10$ & 25.00 & $3.49 \mathrm{E}-10$ & -11.25 & 5386 & 4666 & -13.37 & 3658 & -32.09 \\
\hline & SAV. WATER PLANT: & $3.82 \mathrm{E}-10$ & 4.73E-10 & 23.76 & $3.36 \mathrm{E}-10$ & -12.18 & 5731 & 5011 & -12.56 & 3946 & -31.16 \\
\hline \multirow{6}{*}{$\begin{array}{l}\text { Release from A- } \\
\text { Area to Tims } \\
\text { Branch }\end{array}$} & ROAD A: & $1.80 \mathrm{E}-08$ & $1.76 \mathrm{E}-08$ & -1.90 & 3.13E-09 & -82.61 & 1138 & 821 & -27.85 & 246 & -78.38 \\
\hline & SAVANNAH RIVER: & $5.07 \mathrm{E}-10$ & $6.40 \mathrm{E}-10$ & 26.12 & $1.17 \mathrm{E}-09$ & 131.35 & 1526 & 1166 & -23.58 & 360 & -76.42 \\
\hline & US HIGHWAY 301: & $4.05 \mathrm{E}-10$ & $4.81 \mathrm{E}-10$ & 18.69 & 5.07E-10 & 25.23 & 2966 & 2578 & -13.11 & 1469 & -50.47 \\
\hline & STATE HIGHWAY 119: & $3.32 \mathrm{E}-10$ & $3.75 \mathrm{E}-10$ & 13.01 & $3.36 \mathrm{E}-10$ & 1.48 & 4982 & 4579 & -8.09 & 3082 & -38.14 \\
\hline & BEAUFORT-JASPER: & $3.18 \mathrm{E}-10$ & $3.56 \mathrm{E}-10$ & 12.02 & $3.06 \mathrm{E}-10$ & -3.69 & 5760 & 5386 & -6.50 & 3716 & -35.48 \\
\hline & SAV. WATER PLANT: & $3.12 \mathrm{E}-10$ & $3.48 \mathrm{E}-10$ & 11.52 & $2.95 \mathrm{E}-10$ & -5.45 & 6106 & 5731 & -6.13 & 4004 & -34.42 \\
\hline \multirow{5}{*}{$\begin{array}{l}\text { Release at Road } \\
\text { A (Steel Creek) }\end{array}$} & SAVANNAH RIVER: & $1.78 \mathrm{E}-10$ & $2.71 \mathrm{E}-10$ & 51.81 & $4.24 \mathrm{E}-10$ & 137.80 & 1085 & 799 & -26.37 & 235 & -78.39 \\
\hline & US HIGHWAY 301: & $1.61 \mathrm{E}-10$ & $2.44 \mathrm{E}-10$ & 51.53 & $3.72 \mathrm{E}-10$ & 131.06 & 1906 & 1620 & -14.99 & 838 & -56.05 \\
\hline & STATE HIGHWAY 119: & $1.48 \mathrm{E}-10$ & $2.22 \mathrm{E}-10$ & 49.75 & $3.09 \mathrm{E}-10$ & 108.17 & 3961 & 3629 & -8.38 & 2321 & -41.40 \\
\hline & BEAUFORT-JASPER: & $1.48 \mathrm{E}-10$ & $2.21 \mathrm{E}-10$ & 49.49 & $2.95 \mathrm{E}-10$ & 99.99 & 4744 & 4440 & -6.41 & 2924 & -38.36 \\
\hline & SAV. WATER PLANT: & $1.48 \mathrm{E}-10$ & $2.20 \mathrm{E}-10$ & 48.97 & $2.90 \mathrm{E}-10$ & 96.15 & 5113 & 4772 & -6.67 & 3184 & -37.73 \\
\hline \multirow{5}{*}{$\begin{array}{l}\text { Release to D-Area } \\
\text { Outfall }\end{array}$} & SAVANNAH RIVER: & $2.02 \mathrm{E}-09$ & 2.02E-09 & 0.00 & $2.02 \mathrm{E}-09$ & 0.00 & 216 & 216 & 0.00 & 216 & 0.00 \\
\hline & US HIGHWAY 301: & $8.59 \mathrm{E}-10$ & $8.59 \mathrm{E}-10$ & 0.00 & $8.59 \mathrm{E}-10$ & 0.00 & 1541 & 1541 & 0.00 & 1541 & 0.00 \\
\hline & STATE HIGHWAY 119: & $5.41 \mathrm{E}-10$ & $5.41 \mathrm{E}-10$ & 0.00 & $5.41 \mathrm{E}-10$ & 0.00 & 3672 & 3672 & 0.00 & 3672 & 0.00 \\
\hline & BEAUFORT-JASPER: & $4.92 \mathrm{E}-10$ & $4.92 \mathrm{E}-10$ & 0.00 & $4.92 \mathrm{E}-10$ & 0.00 & 4507 & 4507 & 0.00 & 4507 & 0.00 \\
\hline & SAV. WATER PLANT: & $4.77 \mathrm{E}-10$ & 4.77E-10 & 0.00 & 4.77E-10 & 0.00 & 4882 & 4882 & 0.00 & 4882 & 0.00 \\
\hline \multirow[t]{6}{*}{ Release at F-Area } & ROAD A: & $1.62 \mathrm{E}-07$ & $7.12 \mathrm{E}-08$ & -56.08 & $1.01 \mathrm{E}-08$ & -93.74 & 1296 & 432 & -66.67 & 144 & -88.89 \\
\hline & SAVANNAH RIVER: & $5.34 \mathrm{E}-10$ & $1.73 \mathrm{E}-09$ & 223.41 & $2.45 \mathrm{E}-09$ & 359.57 & 2477 & 922 & -62.79 & 317 & -87.21 \\
\hline & US HIGHWAY 301: & $4.35 \mathrm{E}-10$ & $8.48 \mathrm{E}-10$ & 94.78 & $6.62 \mathrm{E}-10$ & 52.17 & 3744 & 2160 & -42.31 & 1325 & -64.62 \\
\hline & STATE HIGHWAY 119: & $3.46 \mathrm{E}-10$ & $5.26 \mathrm{E}-10$ & 52.08 & $3.86 \mathrm{E}-10$ & 11.60 & 5875 & 4262 & -27.45 & 3082 & -47.55 \\
\hline & BEAUFORT-JASPER: & $3.32 \mathrm{E}-10$ & $4.81 \mathrm{E}-10$ & 44.65 & $3.48 \mathrm{E}-10$ & 4.67 & 6710 & 5098 & -24.03 & 3773 & -43.78 \\
\hline & SAV. WATER PLANT: & $3.27 \mathrm{E}-10$ & $4.66 \mathrm{E}-10$ & 42.53 & $3.35 \mathrm{E}-10$ & 2.43 & 7085 & 5443 & -23.17 & 4090 & -42.28 \\
\hline
\end{tabular}


SRNL-STI-2010-00116

\begin{tabular}{|c|c|c|c|c|c|c|c|c|c|c|c|}
\hline \multicolumn{12}{|c|}{ Table 6 (Cont.) } \\
\hline \multirow{3}{*}{$\begin{array}{c}\text { Release } \\
\text { Location }\end{array}$} & \multirow[t]{3}{*}{ Monitor Location } & \multicolumn{5}{|c|}{ Concentration } & \multicolumn{5}{|c|}{ travel time } \\
\hline & & \multirow{2}{*}{$\begin{array}{c}\text { No Rain } \\
\text { (lb/gal) }\end{array}$} & \multicolumn{2}{|c|}{ 1” in $3 \mathrm{hr}$} & \multicolumn{2}{|c|}{10 ” in $24 \mathrm{hr}$} & \multirow{2}{*}{$\begin{array}{c}\text { No Rain } \\
\text { (min) }\end{array}$} & \multicolumn{2}{|c|}{1 ” in $3 \mathrm{hr}$} & \multicolumn{2}{|c|}{10 ” in $24 \mathrm{hr}$} \\
\hline & & & (lb/gal) & (\% Diff) & (lb/gal) & (\% Diff) & & $(\min )$ & (\% Diff) & $(\min )$ & (\% Diff) \\
\hline \multirow{6}{*}{$\begin{array}{l}\text { Release at Road C } \\
\text { (flowing streams) }\end{array}$} & ROAD A: & $2.25 \mathrm{E}-08$ & 1.89E-08 & -16.14 & 3.36E-09 & -85.09 & 662 & 576 & -13.04 & 173 & -73.82 \\
\hline & SAVANNAH RIVER: & $5.90 \mathrm{E}-10$ & $6.66 \mathrm{E}-10$ & 12.82 & 1.23E-09 & 107.69 & 1051 & 922 & -12.33 & 289 & -72.49 \\
\hline & US HIGHWAY 301: & $4.54 \mathrm{E}-10$ & $4.96 \mathrm{E}-10$ & 9.17 & $5.11 \mathrm{E}-10$ & 12.50 & 2477 & 2362 & -4.65 & 1397 & -43.58 \\
\hline & STATE HIGHWAY 119: & $3.61 \mathrm{E}-10$ & $3.82 \mathrm{E}-10$ & 5.87 & $3.37 \mathrm{E}-10$ & -6.71 & 4493 & 4349 & -3.21 & 2995 & -33.33 \\
\hline & BEAUFORT-JASPER: & $3.44 \mathrm{E}-10$ & $3.63 \mathrm{E}-10$ & 5.39 & $3.07 \mathrm{E}-10$ & -10.78 & 5299 & 5155 & -2.72 & 3658 & -30.97 \\
\hline & SAV. WATER PLANT: & $3.37 \mathrm{E}-10$ & $3.55 \mathrm{E}-10$ & 5.28 & $2.96 \mathrm{E}-10$ & -12.25 & 5645 & 5501 & -2.55 & 3946 & -30.09 \\
\hline \multirow{6}{*}{$\begin{array}{l}\text { Release at } \\
\text { Highway } 278 \text { to } \\
\text { Upper Three Runs }\end{array}$} & ROAD A: & $1.57 \mathrm{E}-08$ & $1.34 \mathrm{E}-08$ & -14.66 & 2.39E-09 & -84.83 & 1512 & 1296 & -14.29 & 389 & -74.29 \\
\hline & SAVANNAH RIVER: & $4.58 \mathrm{E}-10$ & $5.22 \mathrm{E}-10$ & 14.05 & $9.73 \mathrm{E}-10$ & 112.40 & 1901 & 1627 & -14.39 & 505 & -73.45 \\
\hline & US HIGHWAY 301: & $3.74 \mathrm{E}-10$ & $4.16 \mathrm{E}-10$ & 11.22 & $4.84 \mathrm{E}-10$ & 29.42 & 3341 & 3082 & -7.76 & 1614 & -51.69 \\
\hline & STATE HIGHWAY 119: & $3.12 \mathrm{E}-10$ & $3.38 \mathrm{E}-10$ & 8.50 & $3.29 \mathrm{E}-10$ & 5.59 & 5357 & 5069 & -5.38 & 3226 & -39.77 \\
\hline & BEAUFORT-JASPER: & $3.00 \mathrm{E}-10$ & $3.24 \mathrm{E}-10$ & 7.95 & $3.01 \mathrm{E}-10$ & 0.13 & 6163 & 5875 & -4.67 & 3859 & -37.38 \\
\hline & SAV. WATER PLANT: & $2.96 \mathrm{E}-10$ & $3.18 \mathrm{E}-10$ & 7.68 & $2.90 \mathrm{E}-10$ & -1.79 & 6509 & 6221 & -4.42 & 4148 & -36.26 \\
\hline \multirow[t]{6}{*}{ Release at H-Area } & ROAD A: & $1.37 \mathrm{E}-07$ & $5.75 \mathrm{E}-08$ & -57.90 & 7.61E-09 & -94.43 & 1670 & 576 & -65.52 & 173 & -89.66 \\
\hline & SAVANNAH RIVER: & $4.54 \mathrm{E}-10$ & $1.44 \mathrm{E}-09$ & 216.67 & 2.29E-09 & 405.00 & 2794 & 1066 & -61.86 & 346 & -87.63 \\
\hline & US HIGHWAY 301: & $3.94 \mathrm{E}-10$ & $8.06 \mathrm{E}-10$ & 104.81 & $6.47 \mathrm{E}-10$ & 64.42 & 4003 & 2275 & -43.17 & 1354 & -66.19 \\
\hline & STATE HIGHWAY 119: & $3.24 \mathrm{E}-10$ & $5.15 \mathrm{E}-10$ & 58.88 & $3.82 \mathrm{E}-10$ & 17.99 & 6106 & 4320 & -29.25 & 3082 & -49.53 \\
\hline & BEAUFORT-JASPER: & $3.12 \mathrm{E}-10$ & 4.69E-10 & 50.30 & $3.44 \mathrm{E}-10$ & 10.31 & 6941 & 5126 & -26.14 & 3773 & -45.64 \\
\hline & SAV. WATER PLANT: & $3.07 \mathrm{E}-10$ & $4.54 \mathrm{E}-10$ & 47.78 & $3.31 \mathrm{E}-10$ & 7.64 & 7286 & 5501 & -24.51 & 4090 & -43.87 \\
\hline \multirow{6}{*}{$\begin{array}{l}\text { Release at K-Area } \\
\text { Outfall }\end{array}$} & ROAD A: & $3.07 \mathrm{E}-07$ & $1.28 \mathrm{E}-07$ & -58.20 & 1.69E-08 & -94.49 & 130 & 73 & -43.52 & 29 & -77.78 \\
\hline & SAVANNAH RIVER: & $7.23 \mathrm{E}-11$ & $1.38 \mathrm{E}-10$ & 90.57 & $1.96 \mathrm{E}-10$ & 171.72 & 7129 & 3745 & -47.47 & 1094 & -84.65 \\
\hline & US HIGHWAY 301: & $6.59 \mathrm{E}-11$ & $1.25 \mathrm{E}-10$ & 89.09 & $1.78 \mathrm{E}-10$ & 170.12 & 8065 & 4537 & -43.74 & 1728 & -78.57 \\
\hline & STATE HIGHWAY 119: & $6.09 \mathrm{E}-11$ & $1.14 \mathrm{E}-10$ & 86.96 & $1.56 \mathrm{E}-10$ & 155.27 & 10081 & 6553 & -35.00 & 3168 & -68.58 \\
\hline & BEAUFORT-JASPER: & $6.06 \mathrm{E}-11$ & $1.13 \mathrm{E}-10$ & 86.87 & $1.49 \mathrm{E}-10$ & 146.25 & 10801 & 7345 & -32.00 & 3744 & -65.34 \\
\hline & SAV. WATER PLANT: & $6.06 \mathrm{E}-11$ & $1.13 \mathrm{E}-10$ & 86.25 & $1.48 \mathrm{E}-10$ & 144.37 & 11233 & 7777 & -30.76 & 4032 & -64.10 \\
\hline \multirow{4}{*}{$\begin{array}{l}\text { Release to the } \\
\text { Mouth of } \\
\text { Fourmile Branch }\end{array}$} & US HIGHWAY 301: & $9.35 \mathrm{E}-10$ & $9.42 \mathrm{E}-10$ & 0.81 & $6.47 \mathrm{E}-10$ & -30.77 & 1210 & 1181 & -2.38 & 979 & -19.05 \\
\hline & STATE HIGHWAY 119: & $5.45 \mathrm{E}-10$ & $5.45 \mathrm{E}-10$ & 0.00 & $3.79 \mathrm{E}-10$ & -30.56 & 3226 & 3197 & -0.89 & 2707 & -16.07 \\
\hline & BEAUFORT-JASPER: & 4.92E-10 & $4.92 \mathrm{E}-10$ & 0.00 & 3.39E-10 & -31.08 & 4032 & 3974 & -1.43 & 3398 & -15.71 \\
\hline & SAV. WATER PLANT: & $4.73 \mathrm{E}-10$ & 4.69E-10 & -0.80 & $3.26 \mathrm{E}-10$ & -31.04 & 4378 & 4320 & -1.32 & 3686 & -15.79 \\
\hline \multirow{4}{*}{$\begin{array}{l}\text { Release to the } \\
\text { Mouth of Beaver } \\
\text { Dam Creek }\end{array}$} & US HIGHWAY 301: & $9.77 \mathrm{E}-10$ & 9.77E-10 & 0.00 & $9.77 \mathrm{E}-10$ & 0.00 & 1354 & 1354 & 0.00 & 1354 & 0.00 \\
\hline & STATE HIGHWAY 119: & $5.45 \mathrm{E}-10$ & $5.45 \mathrm{E}-10$ & 0.00 & $5.45 \mathrm{E}-10$ & 0.00 & 3470 & 3470 & 0.00 & 3470 & 0.00 \\
\hline & BEAUFORT-JASPER: & $4.96 \mathrm{E}-10$ & $4.96 \mathrm{E}-10$ & 0.00 & $4.96 \mathrm{E}-10$ & 0.00 & 4306 & 4306 & 0.00 & 4306 & 0.00 \\
\hline & SAV. WATER PLANT: & $4.77 \mathrm{E}-10$ & $4.77 \mathrm{E}-10$ & 0.00 & 4.77E-10 & 0.00 & 4666 & 4666 & 0.00 & 4666 & 0.00 \\
\hline
\end{tabular}


SRNL-STI-2010-00116

\begin{tabular}{|c|c|c|c|c|c|c|c|c|c|c|c|}
\hline \multicolumn{12}{|c|}{ Table 6 (Cont.) } \\
\hline & & \multicolumn{5}{|c|}{ Concentration } & \multicolumn{5}{|c|}{ travel time } \\
\hline & & \multirow{2}{*}{$\begin{array}{c}\text { No Rain } \\
\text { (lb/gal) }\end{array}$} & \multicolumn{2}{|c|}{1 ” in $3 \mathrm{hr}$} & \multicolumn{2}{|c|}{10 ” in $24 \mathrm{hr}$} & \multirow{2}{*}{$\begin{array}{c}\text { No Rain } \\
\text { (min) }\end{array}$} & \multicolumn{2}{|c|}{1 ” in $3 \mathrm{hr}$} & \multicolumn{2}{|c|}{10 ” in $24 \mathrm{hr}$} \\
\hline & & & (lb/gal) & (\% Diff) & (lb/gal) & (\% Diff) & & $(\min )$ & (\% Diff) & $(\min )$ & (\% Diff) \\
\hline \multirow{4}{*}{$\begin{array}{l}\text { Release to the } \\
\text { Mouth of Lower } \\
\text { Three Runs }\end{array}$} & US HIGHWAY 301: & $2.12 \mathrm{E}-09$ & $2.76 \mathrm{E}-09$ & 30.18 & $1.05 \mathrm{E}-09$ & -50.54 & 422 & 376 & -10.95 & 233 & -44.81 \\
\hline & STATE HIGHWAY 119: & 1.00E-09 & $1.12 \mathrm{E}-09$ & 11.33 & 4.09E-10 & -59.24 & 2449 & 2283 & -6.79 & 1444 & -41.06 \\
\hline & BEAUFORT-JASPER: & 8.97E-10 & $9.84 \mathrm{E}-10$ & 9.70 & $3.54 \mathrm{E}-10$ & -60.51 & 3260 & 3039 & -6.79 & 1933 & -40.71 \\
\hline & SAV. WATER PLANT: & $8.59 \mathrm{E}-10$ & $9.39 \mathrm{E}-10$ & 9.25 & $3.36 \mathrm{E}-10$ & -60.88 & 3601 & 3371 & -6.40 & 2148 & -40.35 \\
\hline \multirow{6}{*}{$\begin{array}{l}\text { Release from H- } \\
\text { Area to McQueen } \\
\text { Branch }\end{array}$} & ROAD A: & $1.46 \mathrm{E}-08$ & $1.51 \mathrm{E}-08$ & 3.37 & 2.37E-09 & -83.78 & 1648 & 1232 & -25.20 & 376 & -77.20 \\
\hline & SAVANNAH RIVER: & $4.39 \mathrm{E}-10$ & $5.90 \mathrm{E}-10$ & 34.48 & $9.69 \mathrm{E}-10$ & 120.69 & 2016 & 1574 & -21.93 & 475 & -76.43 \\
\hline & US HIGHWAY 301: & $3.82 \mathrm{E}-10$ & $5.00 \mathrm{E}-10$ & 30.69 & $4.88 \mathrm{E}-10$ & 27.72 & 3435 & 3002 & -12.59 & 1600 & -53.43 \\
\hline & STATE HIGHWAY 119: & $3.42 \mathrm{E}-10$ & $4.35 \mathrm{E}-10$ & 27.35 & $3.30 \mathrm{E}-10$ & -3.32 & 5472 & 5011 & -8.42 & 3198 & -41.56 \\
\hline & BEAUFORT-JASPER: & $3.37 \mathrm{E}-10$ & $4.24 \mathrm{E}-10$ & 25.84 & $3.02 \mathrm{E}-10$ & -10.45 & 6283 & 5795 & -7.77 & 3860 & -38.56 \\
\hline & SAV. WATER PLANT: & $3.35 \mathrm{E}-10$ & $4.20 \mathrm{E}-10$ & 25.43 & $2.91 \mathrm{E}-10$ & -12.99 & 6624 & 6136 & -7.37 & 4120 & -37.81 \\
\hline \multirow{4}{*}{$\begin{array}{l}\text { Release to the } \\
\text { Mouth of Upper } \\
\text { Three Runs }\end{array}$} & US HIGHWAY 301: & $8.29 \mathrm{E}-10$ & 8.33E-10 & 0.46 & $5.68 \mathrm{E}-10$ & -31.51 & 1469 & 1454 & -0.98 & 1124 & -23.45 \\
\hline & STATE HIGHWAY 119: & $5.15 \mathrm{E}-10$ & $5.15 \mathrm{E}-10$ & 0.00 & $3.54 \mathrm{E}-10$ & -31.32 & 3456 & 3456 & 0.00 & 2737 & -20.82 \\
\hline & BEAUFORT-JASPER: & $4.69 \mathrm{E}-10$ & $4.69 \mathrm{E}-10$ & 0.00 & $3.19 \mathrm{E}-10$ & -32.10 & 4262 & 4234 & -0.68 & 3370 & -20.95 \\
\hline & SAV. WATER PLANT: & $4.50 \mathrm{E}-10$ & $4.50 \mathrm{E}-10$ & 0.00 & $3.07 \mathrm{E}-10$ & -31.93 & 4608 & 4579 & -0.63 & 3658 & -20.61 \\
\hline \multirow{4}{*}{$\begin{array}{l}\text { Release to the } \\
\text { Mouth of Steel } \\
\text { Creek-Pen Branch }\end{array}$} & US HIGHWAY 301: & $1.27 \mathrm{E}-09$ & $1.15 \mathrm{E}-09$ & -9.55 & $6.66 \mathrm{E}-10$ & -47.46 & 956 & 883 & -7.72 & 635 & -33.56 \\
\hline & STATE HIGHWAY 119: & $7.91 \mathrm{E}-10$ & $7.46 \mathrm{E}-10$ & -5.74 & $4.35 \mathrm{E}-10$ & -44.98 & 3076 & 2845 & -7.49 & 2107 & -31.51 \\
\hline & BEAUFORT-JASPER: & $7.31 \mathrm{E}-10$ & $6.96 \mathrm{E}-10$ & -4.66 & $3.97 \mathrm{E}-10$ & -45.60 & 3924 & 3601 & -8.23 & 2682 & -31.65 \\
\hline & SAV. WATER PLANT: & $7.12 \mathrm{E}-10$ & $6.78 \mathrm{E}-10$ & -4.79 & $3.86 \mathrm{E}-10$ & -45.74 & 4283 & 3933 & -8.18 & 2941 & -31.33 \\
\hline \multirow{5}{*}{$\begin{array}{l}\text { Release at PAR } \\
\text { Pond Dam }\end{array}$} & SAVANNAH RIVER: & $3.60 \mathrm{E}-10$ & $1.67 \mathrm{E}-09$ & 364.21 & $8.02 \mathrm{E}-10$ & 123.15 & 2938 & 910 & -69.02 & 304 & -89.64 \\
\hline & US HIGHWAY 301: & $3.24 \mathrm{E}-10$ & 1.35E-09 & 317.04 & 1.03E-09 & 218.92 & 3316 & 1270 & -61.71 & 520 & -84.33 \\
\hline & STATE HIGHWAY 119: & $2.92 \mathrm{E}-10$ & $8.86 \mathrm{E}-10$ & 203.51 & $4.09 \mathrm{E}-10$ & 40.08 & 5343 & 3187 & -40.36 & 1730 & -67.62 \\
\hline & BEAUFORT-JASPER: & $2.89 \mathrm{E}-10$ & $8.18 \mathrm{E}-10$ & 182.73 & $3.54 \mathrm{E}-10$ & 22.52 & 6154 & 3933 & -36.09 & 2220 & -63.93 \\
\hline & SAV. WATER PLANT: & $2.88 \mathrm{E}-10$ & $7.91 \mathrm{E}-10$ & 175.00 & $3.36 \mathrm{E}-10$ & 16.84 & 6495 & 4265 & -34.34 & 2435 & -62.51 \\
\hline \multirow{4}{*}{$\begin{array}{l}\text { Release to S. } \\
\text { River at } 6 \text { miles } \\
\text { downstream from } \\
\text { the Lock \& Dam }\end{array}$} & US HIGHWAY 301: & $6.78 \mathrm{E}-10$ & $6.78 \mathrm{E}-10$ & 0.00 & $6.78 \mathrm{E}-10$ & 0.00 & 2362 & 2362 & 0.00 & 2362 & 0.00 \\
\hline & STATE HIGHWAY 119: & $4.73 \mathrm{E}-10$ & 4.73E-10 & 0.00 & 4.73E-10 & 0.00 & 4406 & 4406 & 0.00 & 4406 & 0.00 \\
\hline & BEAUFORT-JASPER: & $4.35 \mathrm{E}-10$ & $4.35 \mathrm{E}-10$ & 0.00 & $4.35 \mathrm{E}-10$ & 0.00 & 5213 & 5213 & 0.00 & 5213 & 0.00 \\
\hline & SAV. WATER PLANT: & $4.24 \mathrm{E}-10$ & $4.24 \mathrm{E}-10$ & 0.00 & $4.24 \mathrm{E}-10$ & 0.00 & 5558 & 5558 & 0.00 & 5558 & 0.00 \\
\hline \multirow{5}{*}{$\begin{array}{l}\text { Release at Road } \\
\text { A (Upper Three } \\
\text { Runs) }\end{array}$} & SAVANNAH RIVER: & $9.65 \mathrm{E}-10$ & $1.09 \mathrm{E}-09$ & 12.94 & $1.93 \mathrm{E}-09$ & 100.39 & 389 & 346 & -11.11 & 116 & -70.22 \\
\hline & US HIGHWAY 301: & $6.13 \mathrm{E}-10$ & $6.47 \mathrm{E}-10$ & 5.56 & $5.45 \mathrm{E}-10$ & -11.11 & 1843 & 1786 & -3.13 & 1224 & -33.59 \\
\hline & STATE HIGHWAY 119: & $4.39 \mathrm{E}-10$ & $4.54 \mathrm{E}-10$ & 3.45 & $3.47 \mathrm{E}-10$ & -20.86 & 3830 & 3802 & -0.75 & 2838 & -25.91 \\
\hline & BEAUFORT-JASPER: & $4.09 \mathrm{E}-10$ & $4.20 \mathrm{E}-10$ & 2.78 & $3.14 \mathrm{E}-10$ & -23.15 & 4637 & 4579 & -1.24 & 3485 & -24.83 \\
\hline & SAV. WATER PLANT: & $3.97 \mathrm{E}-10$ & $4.09 \mathrm{E}-10$ & 2.86 & $3.02 \mathrm{E}-10$ & -24.09 & 4982 & 4925 & -1.16 & 3745 & -24.83 \\
\hline
\end{tabular}


Figure 1

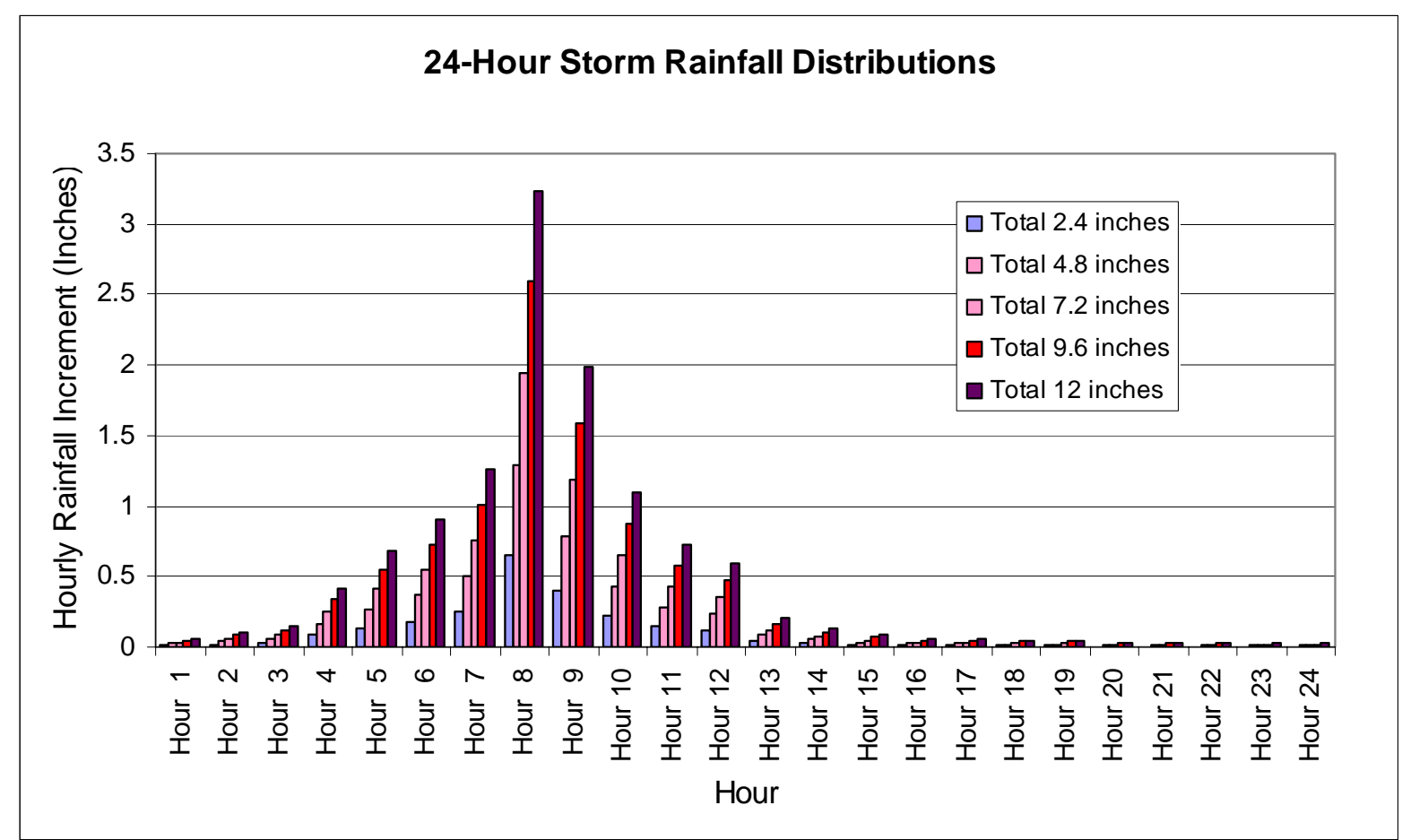


Figure 2

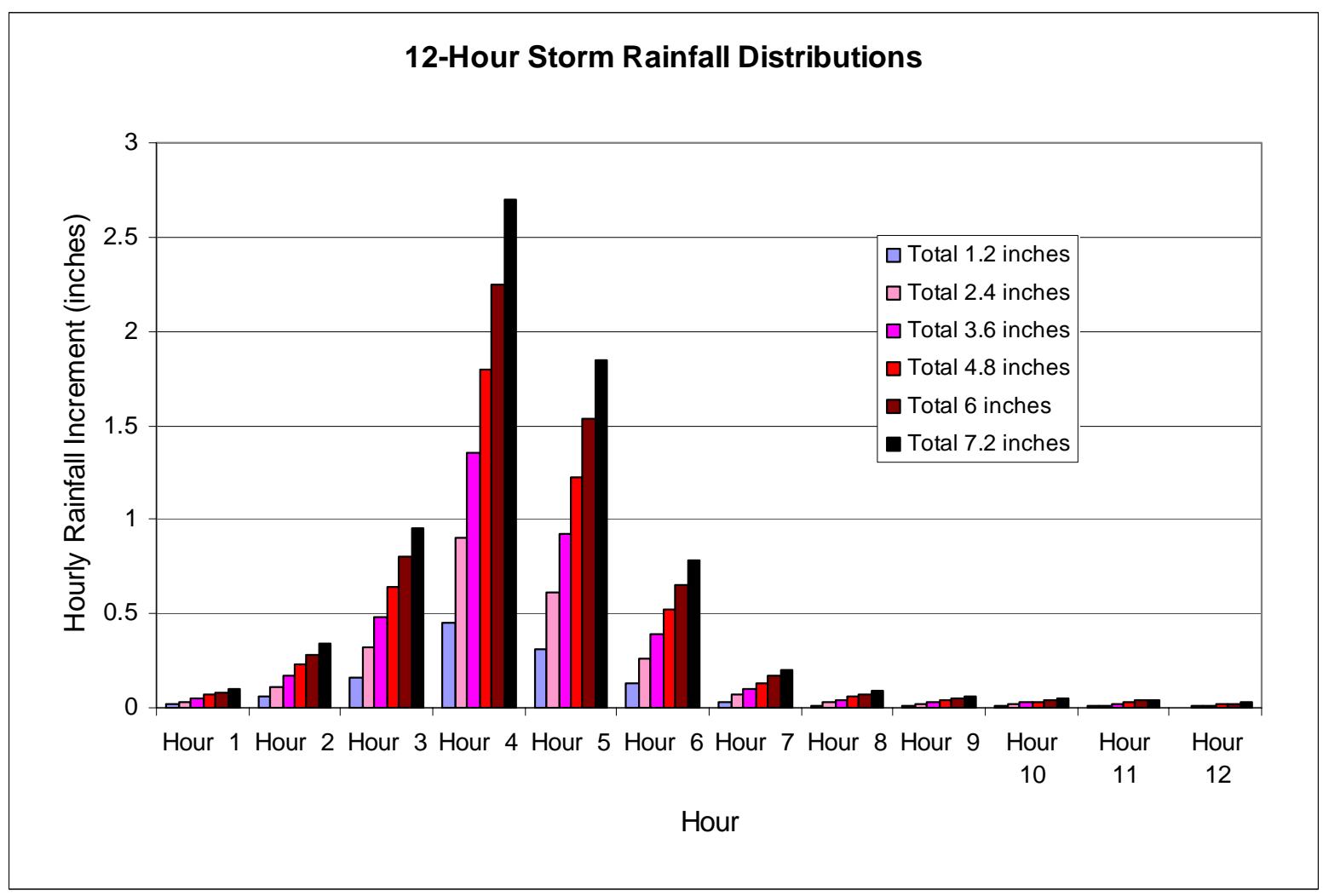


Figure 3

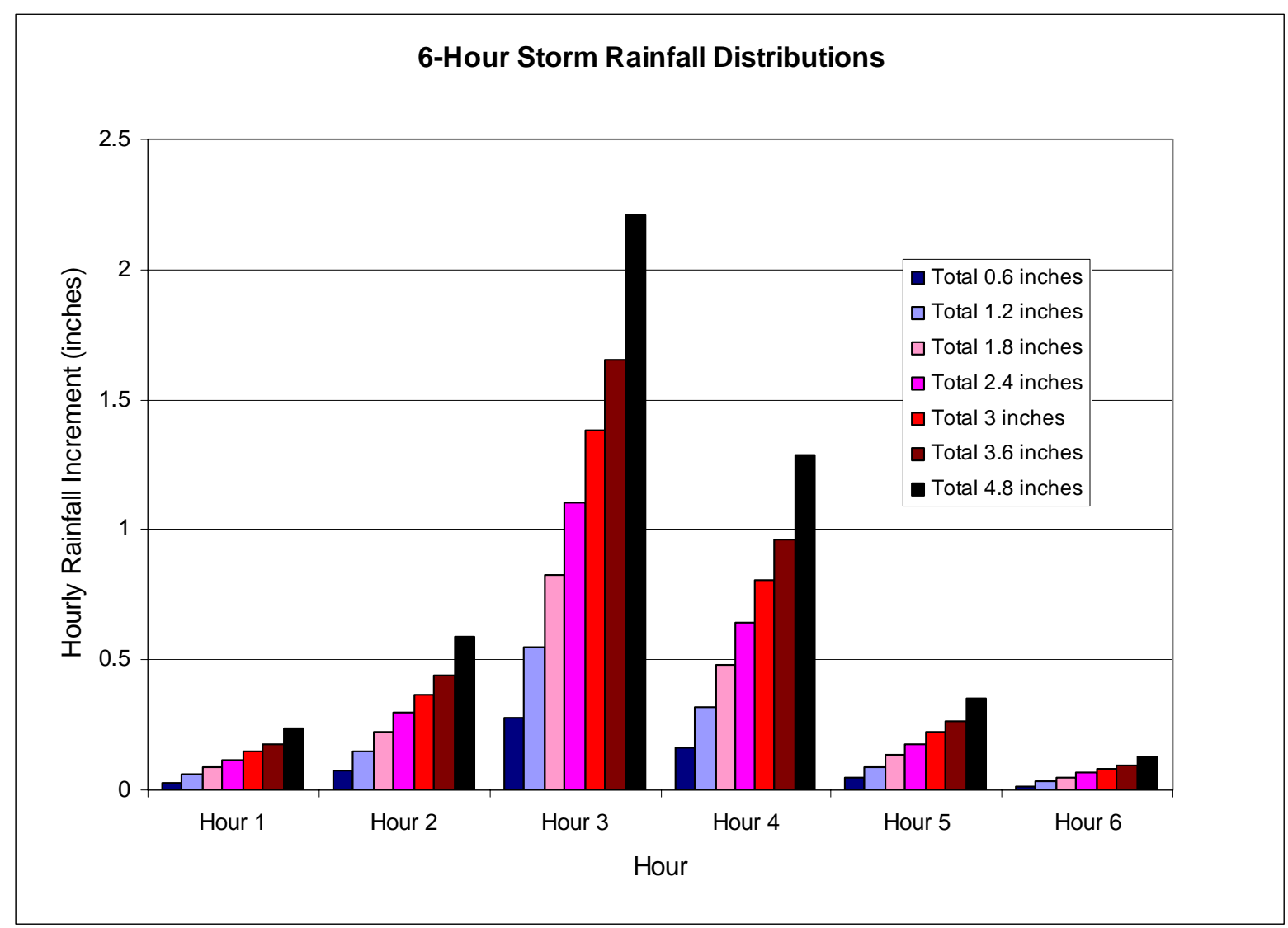


Figure 4

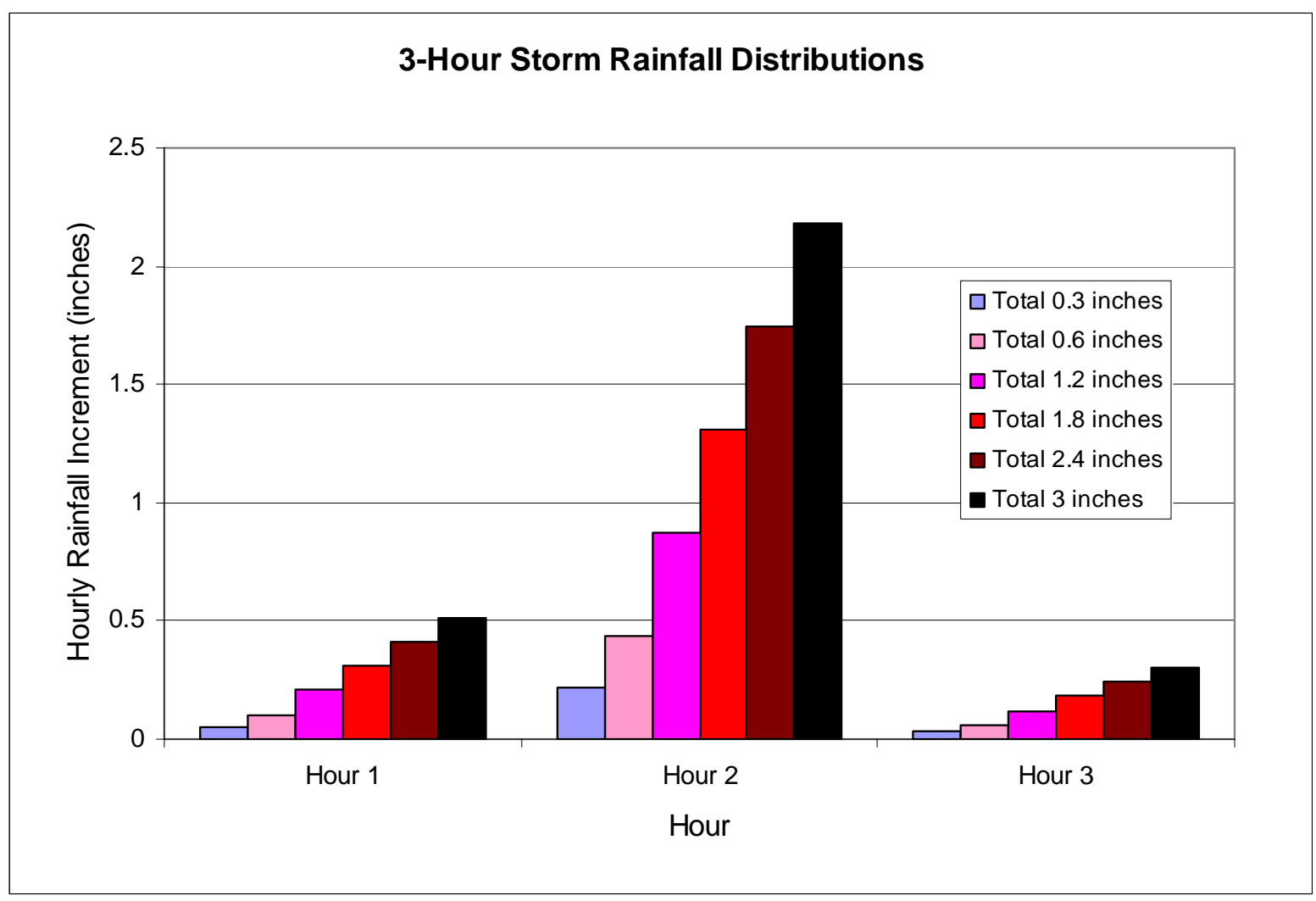


Figure 5

\section{Digital Elevation Model for Savannah River Site}

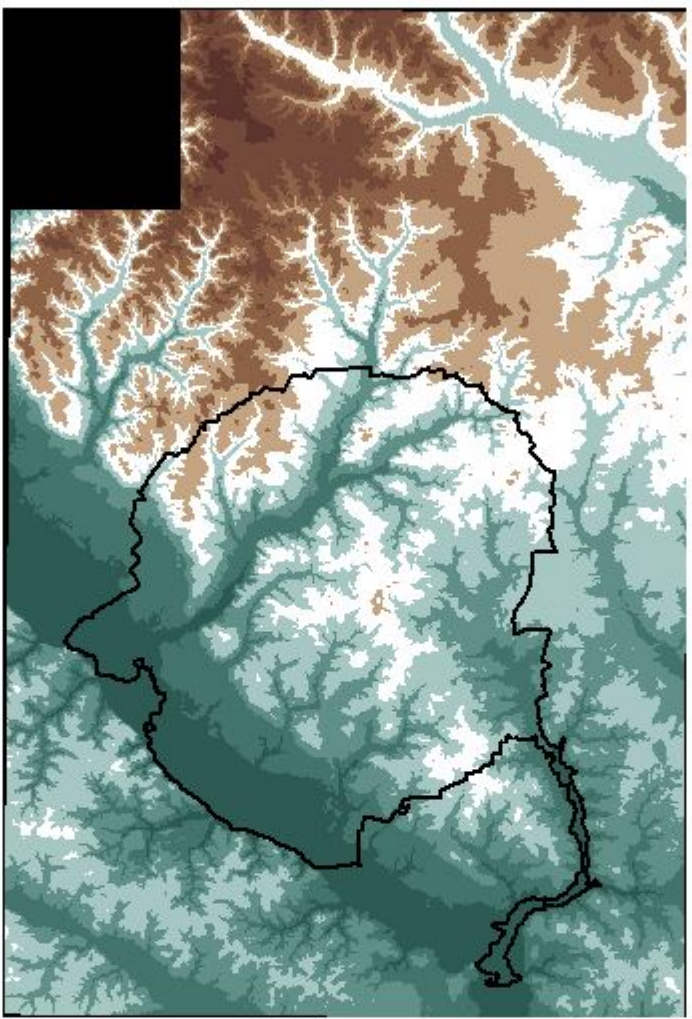

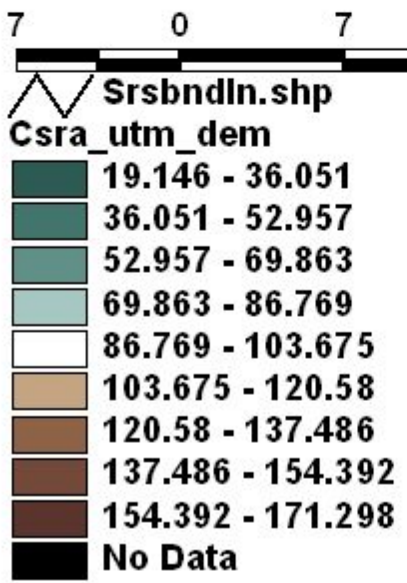

14 Miles 
Figure 6
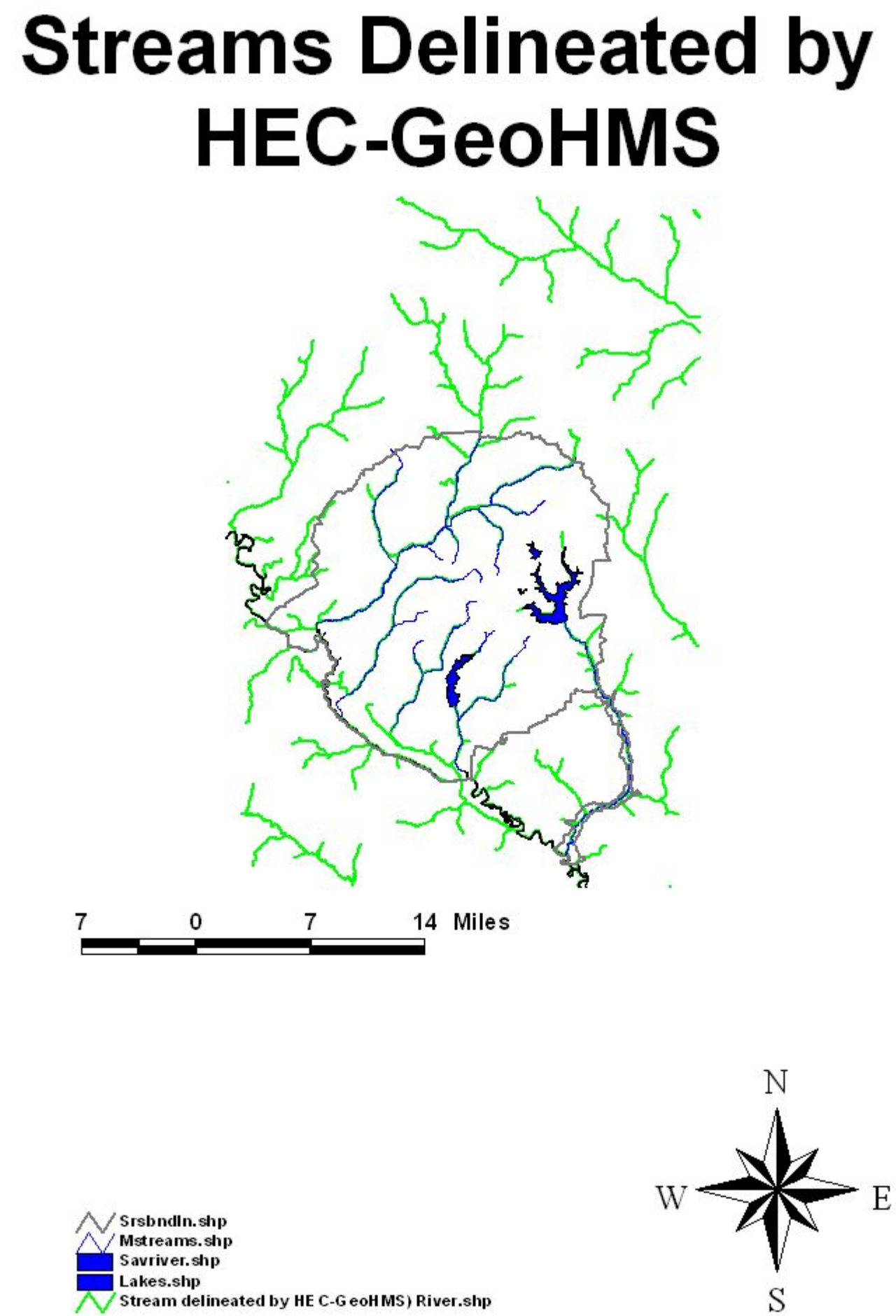
Figure 7

\section{Watershed Delineated by HEC-GeoHMS}

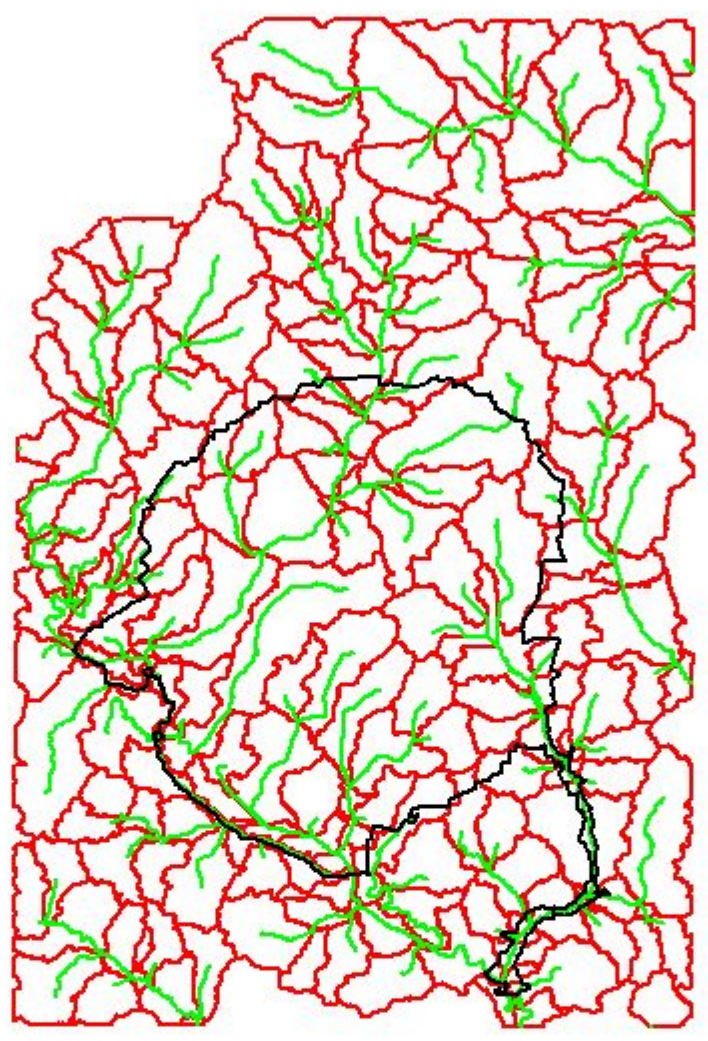

7

7

14 Miles

$\widehat{N}_{\text {Srsbondin.shp }}$

Strea ms Delineated by HEC-Geo HM SRiver shp

Watershed Delineated by HEC.GeoHM SW hhedshp.Shp

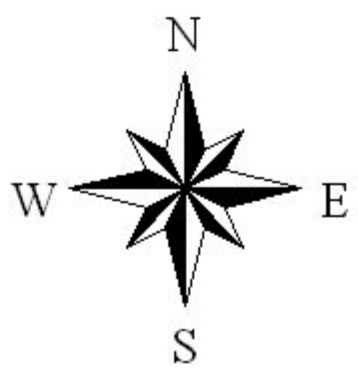


Figure 8

\section{Upper Three Runs Watershed}

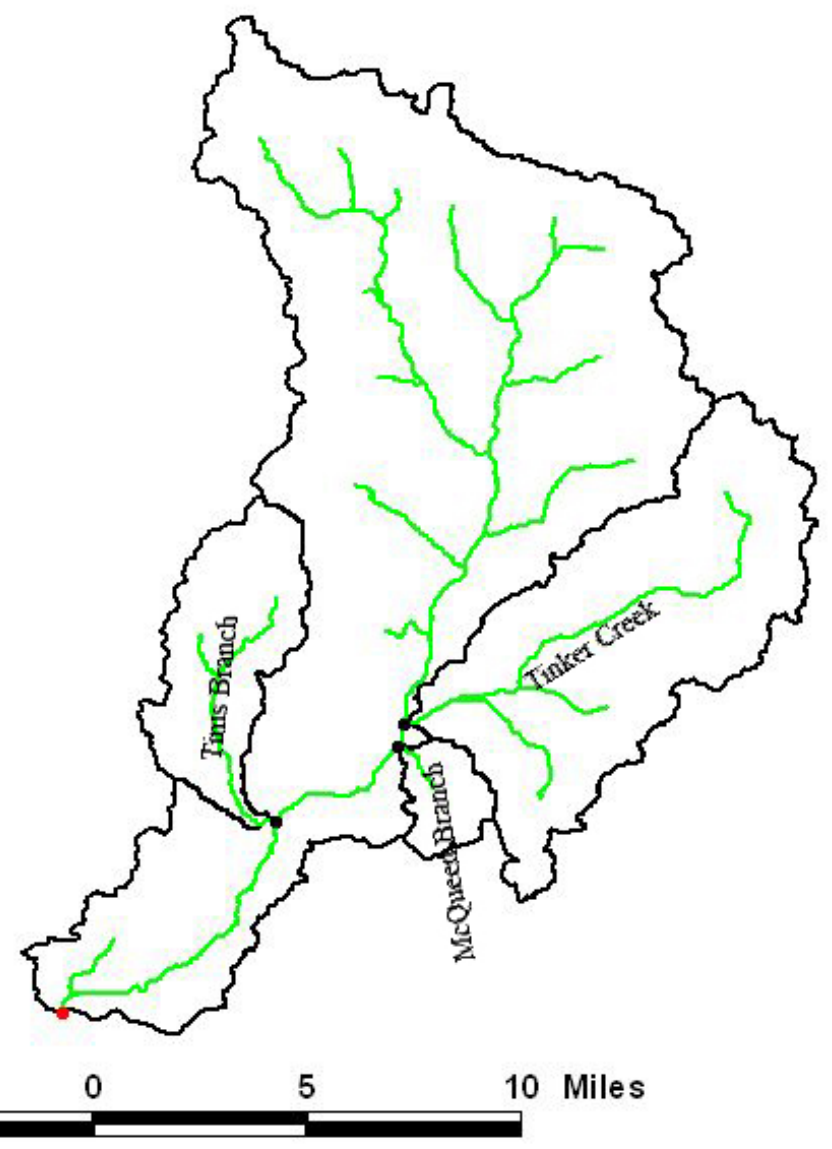

Utr.shp

- MidPoint

- Outlet

River.Shp

watershd.Shp

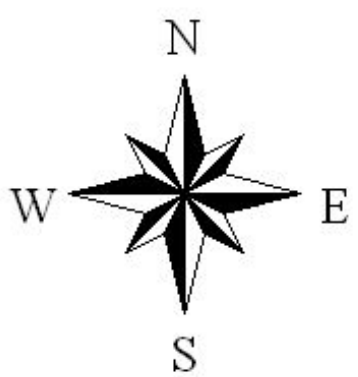


Figure 9

\section{Fourmile Branch Watershed}

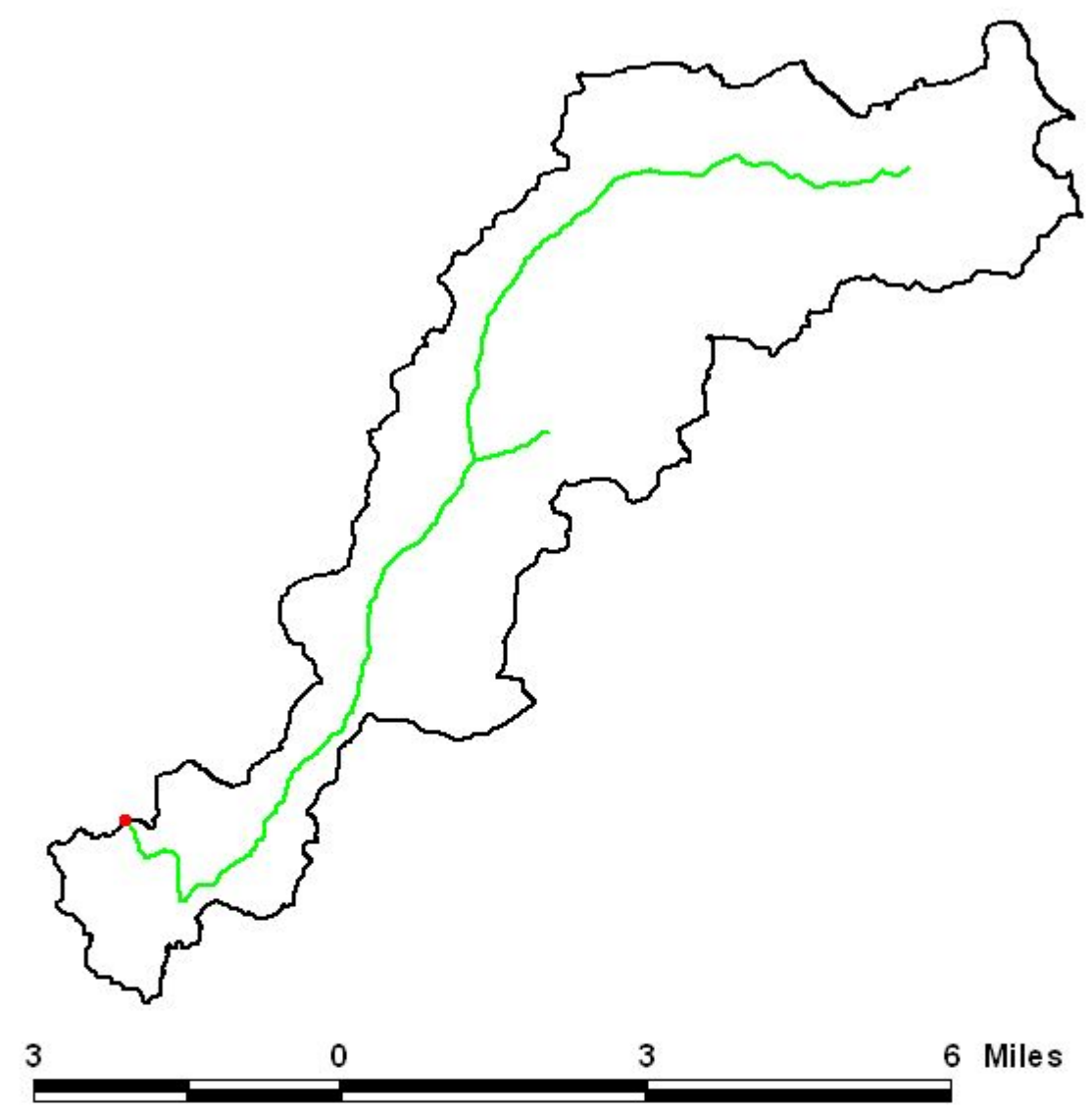

Fmb.shp

- Outlet

River.Shp

watershd.Shp

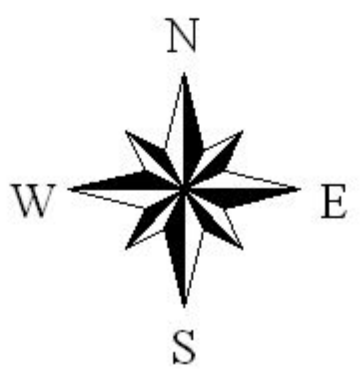


Figure 10

\section{Pen Branch Watershed}
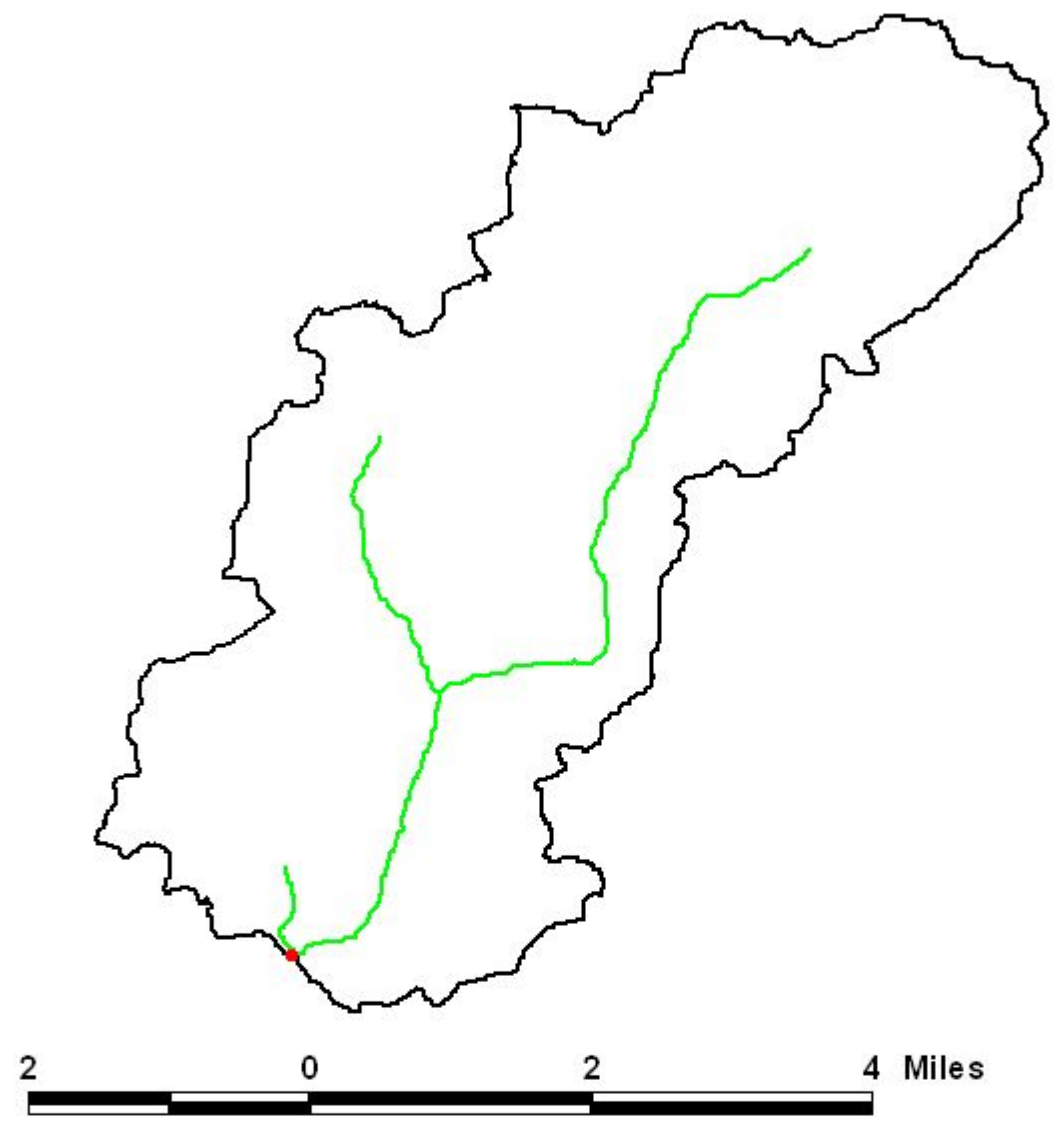

Penb.shp

- Outlet

$\checkmark$ River.Shp watershd.Shp

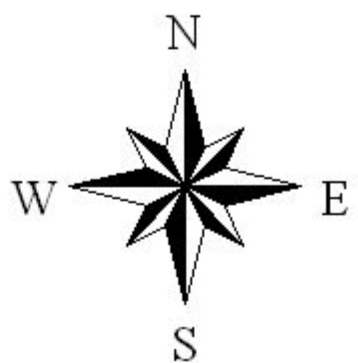


Figure 11

\section{Steel Creek Watershed}
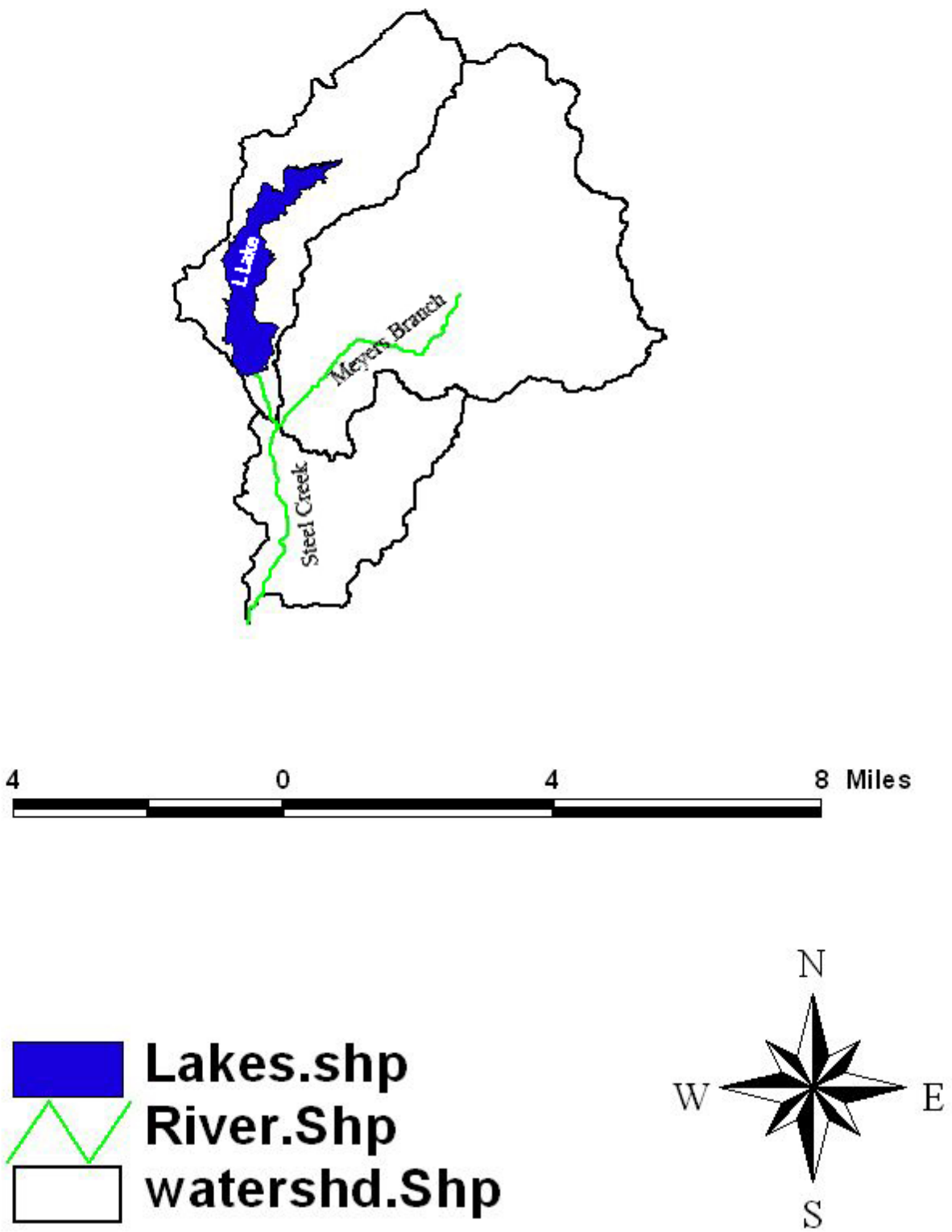
Figure 12

\section{Lower Three Runs Watershed}
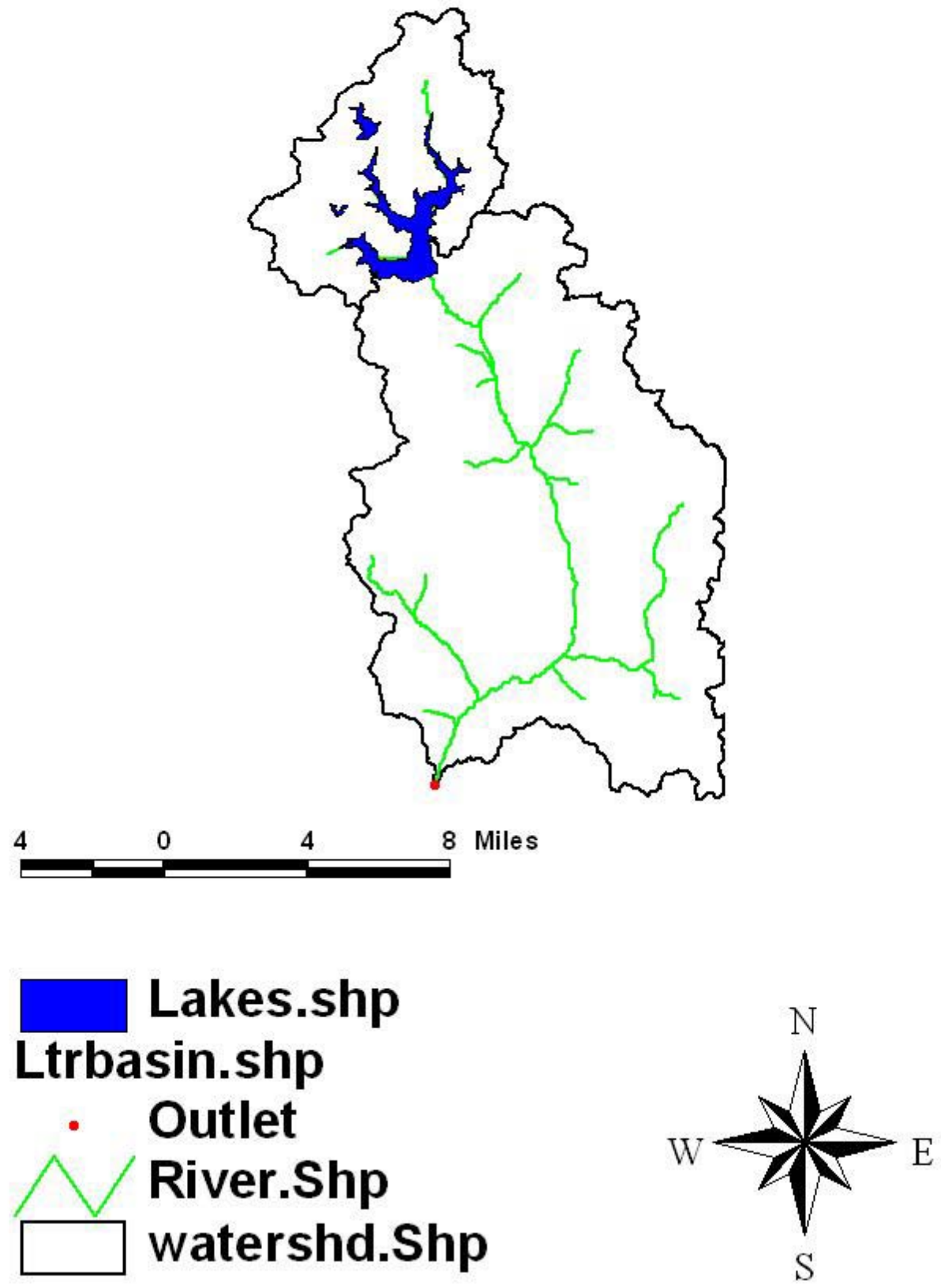
Figure 13. HEC-HMS Simulation for the Upper Three Runs Watershed Runoff Hydrograph (2.8 Inches of Rainfall in 3 Hours)

Subbasin "R860W160" Results for Run "Run 0803"

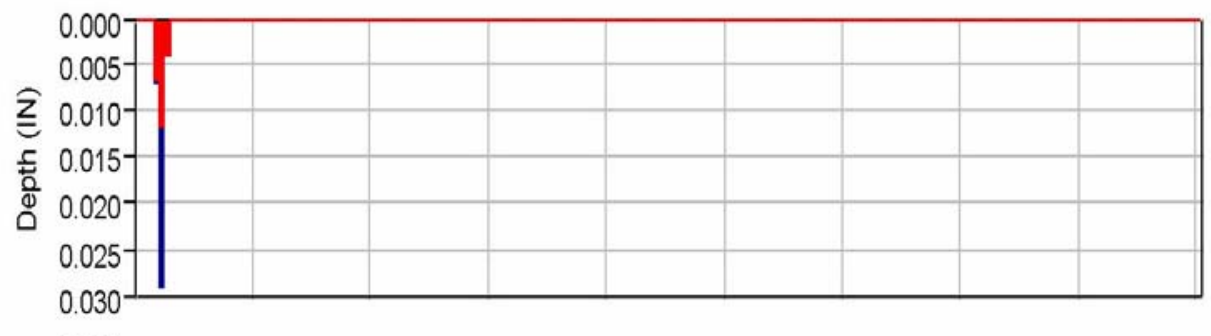

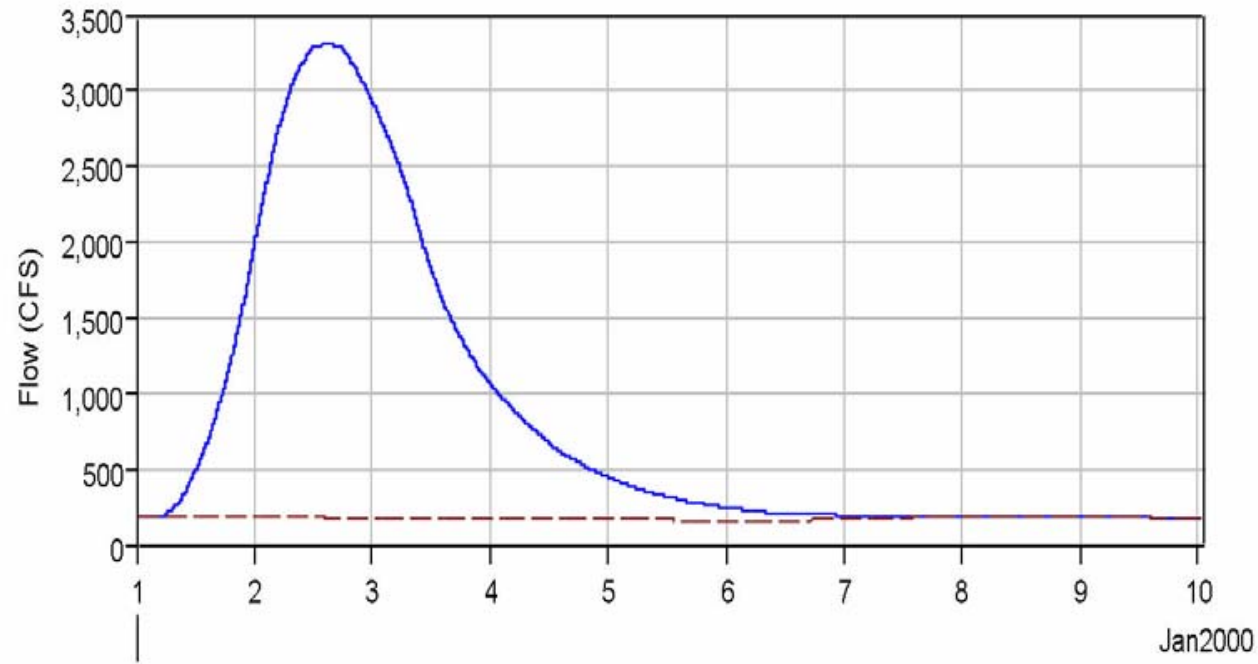

Run:Run 0803 Element:R860W160 Result:Precipitation

Run:RUN 0803 Element:R860W160 Result:Precipitation Loss

Run:RUN 0803 Element:R860W160 Result:Outflow

Run:RUN 0803 Element:R860W160 Result:Baseflow 
Figure 14

Upper Three Runs Peak Runoff Flow as a Function of Total Rainfall Rainfall Duration $=1$ hour

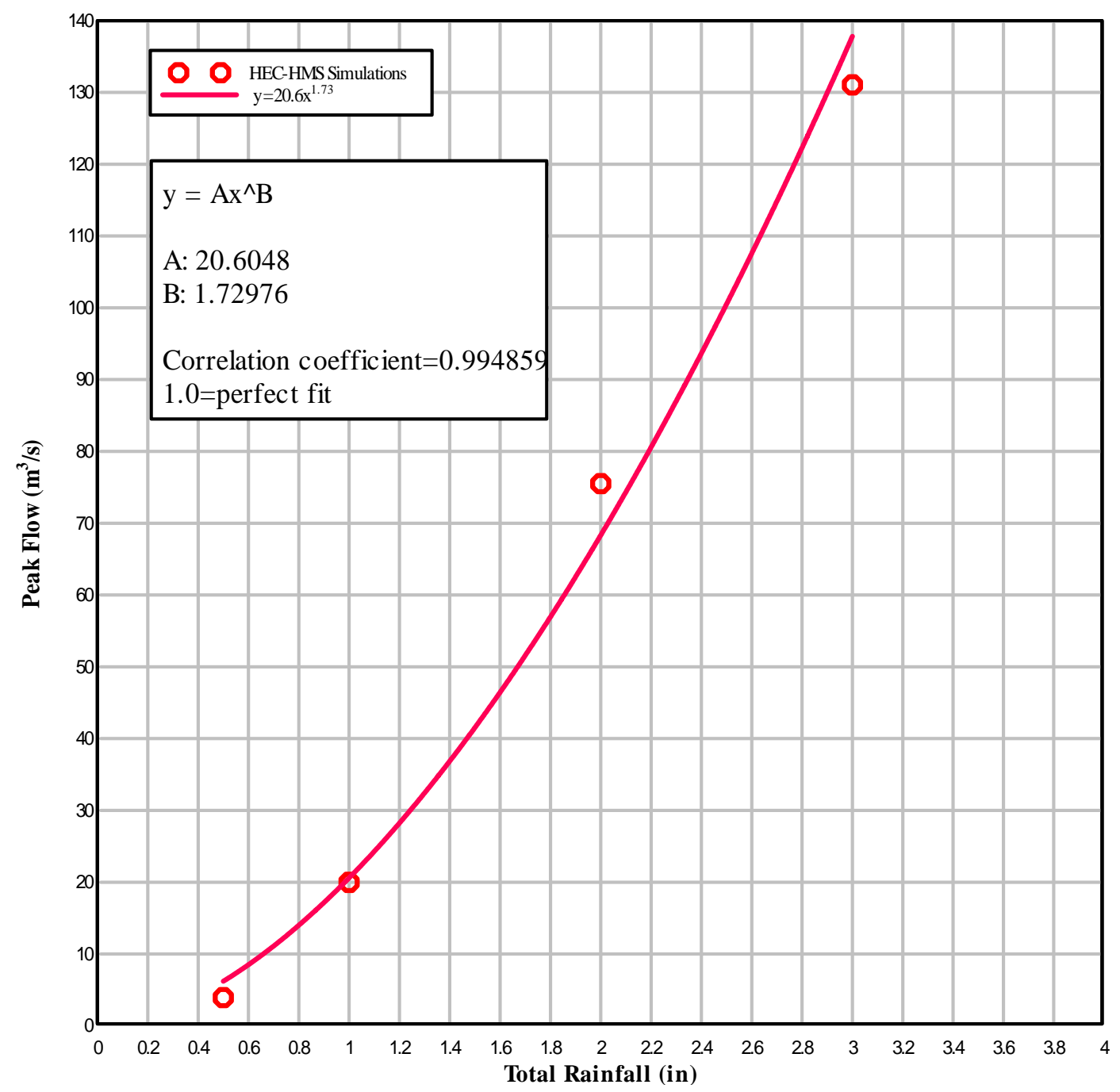


Figure 15

Upper Three Runs Peak Runoff Flow as a Function of Total Rainfall Rainfall Duration $\mathbf{=} \mathbf{3}$ hours

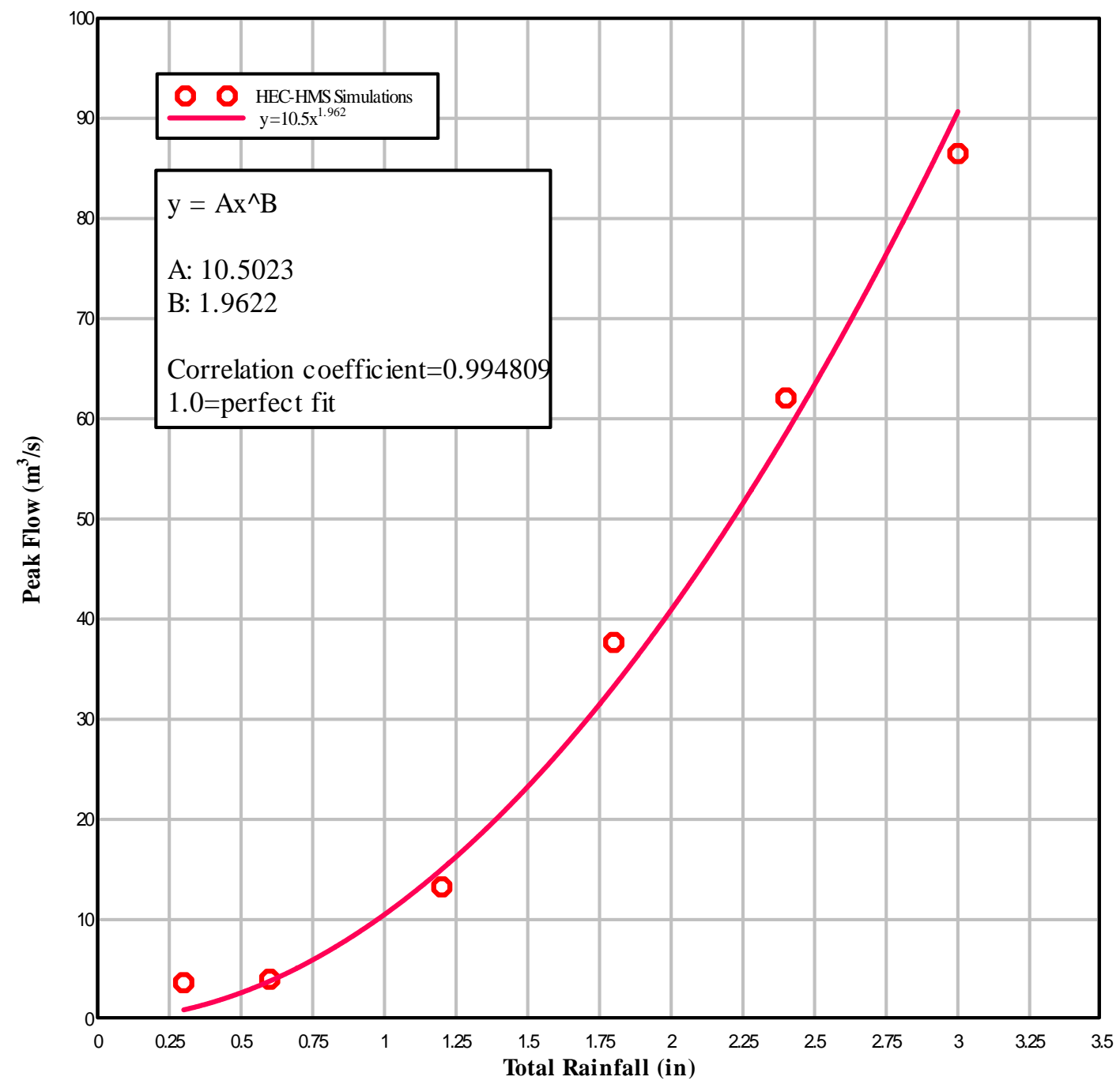


Figure 16

Upper Three Runs Peak Runoff Flow as a Function of Total Rainfall

Rainfall Duration $=6$ hours

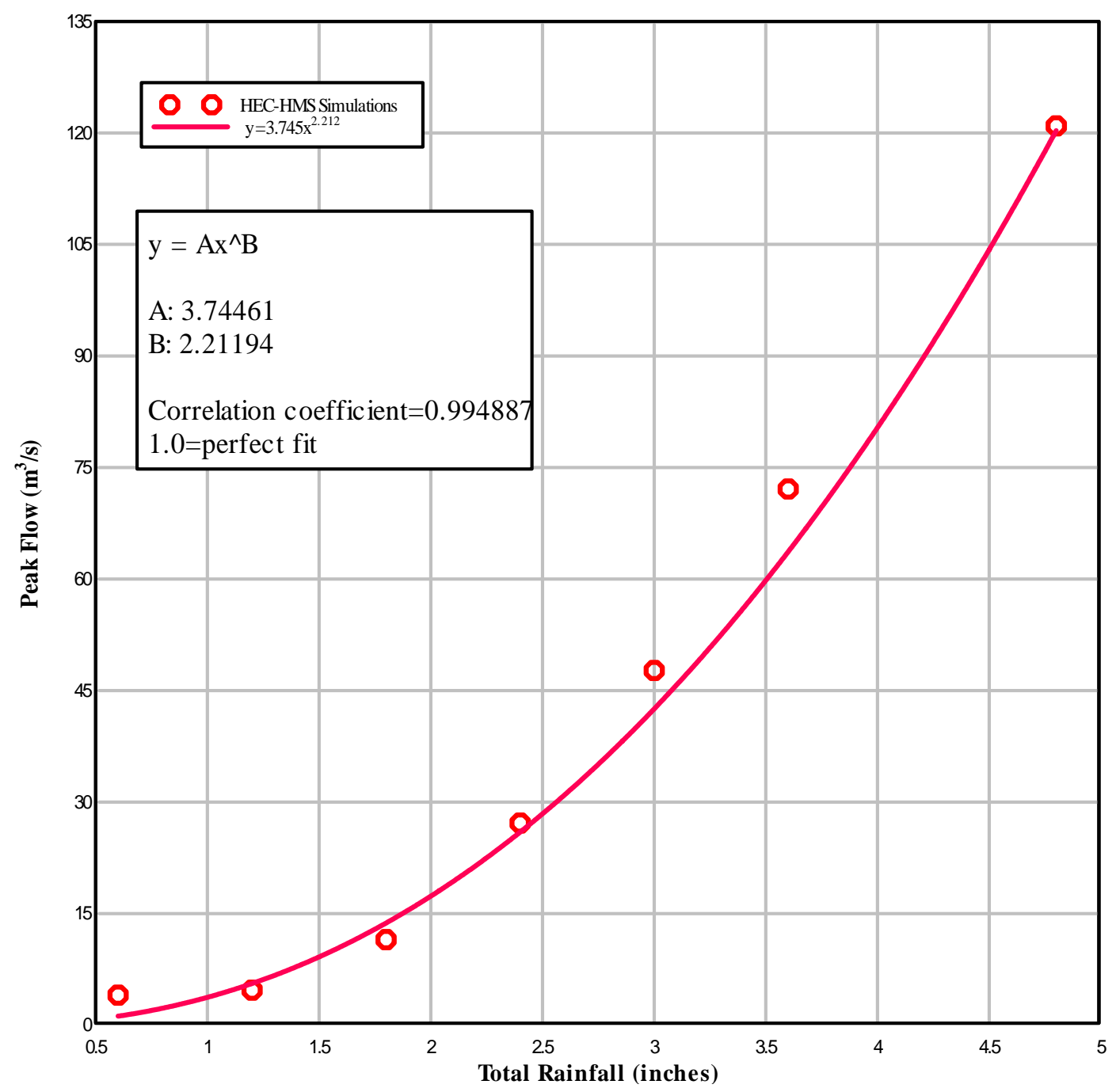


Figure 17

Upper Three Runs Peak Runoff Flow as a Function of Total Rainfall Rainfall Duration $=12$ Hours

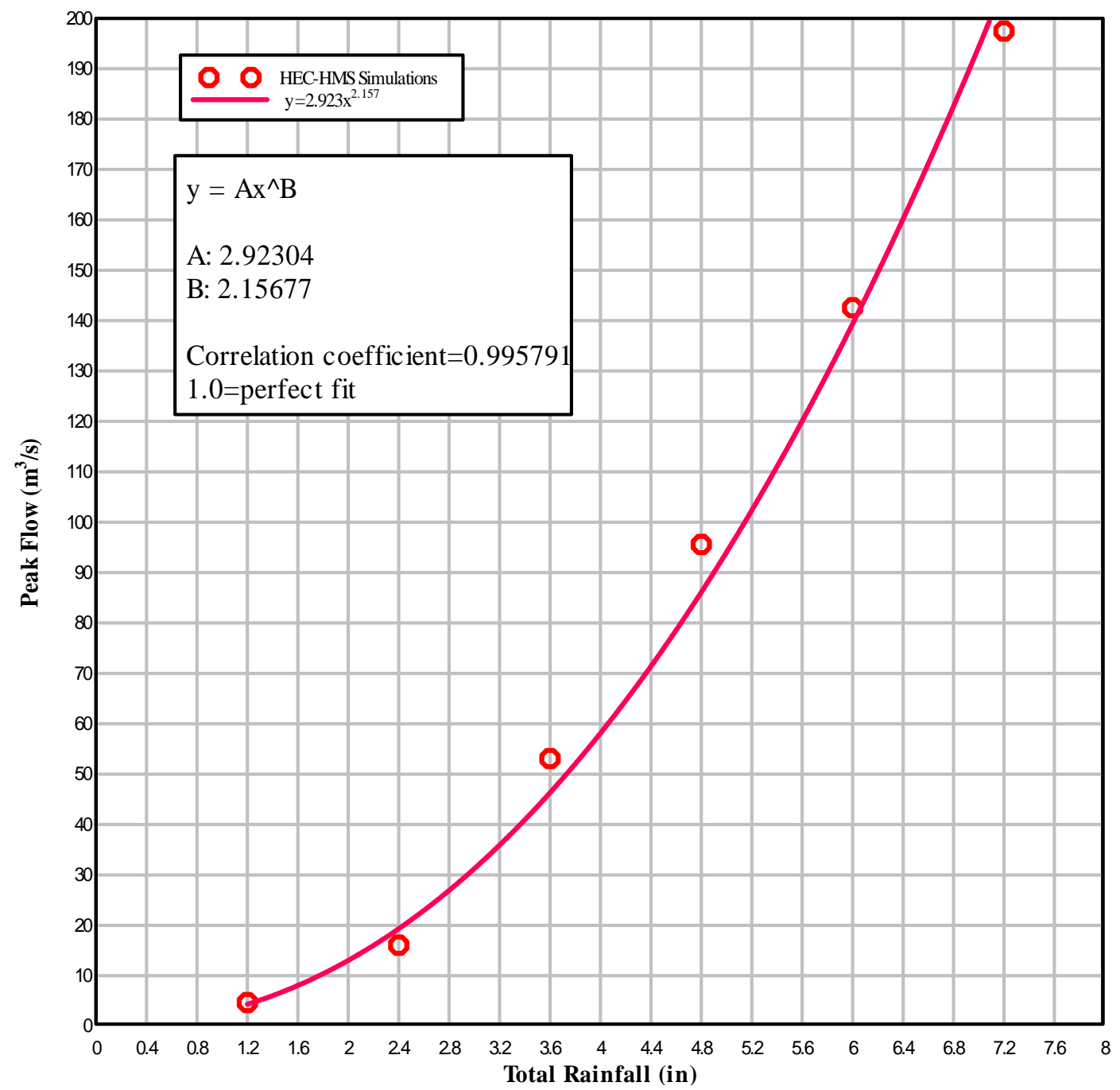


Figure 18

Upper Three Runs Peak Runoff Flow as a Function of Total Rainfall Rainfall Duration $=24$ Hours

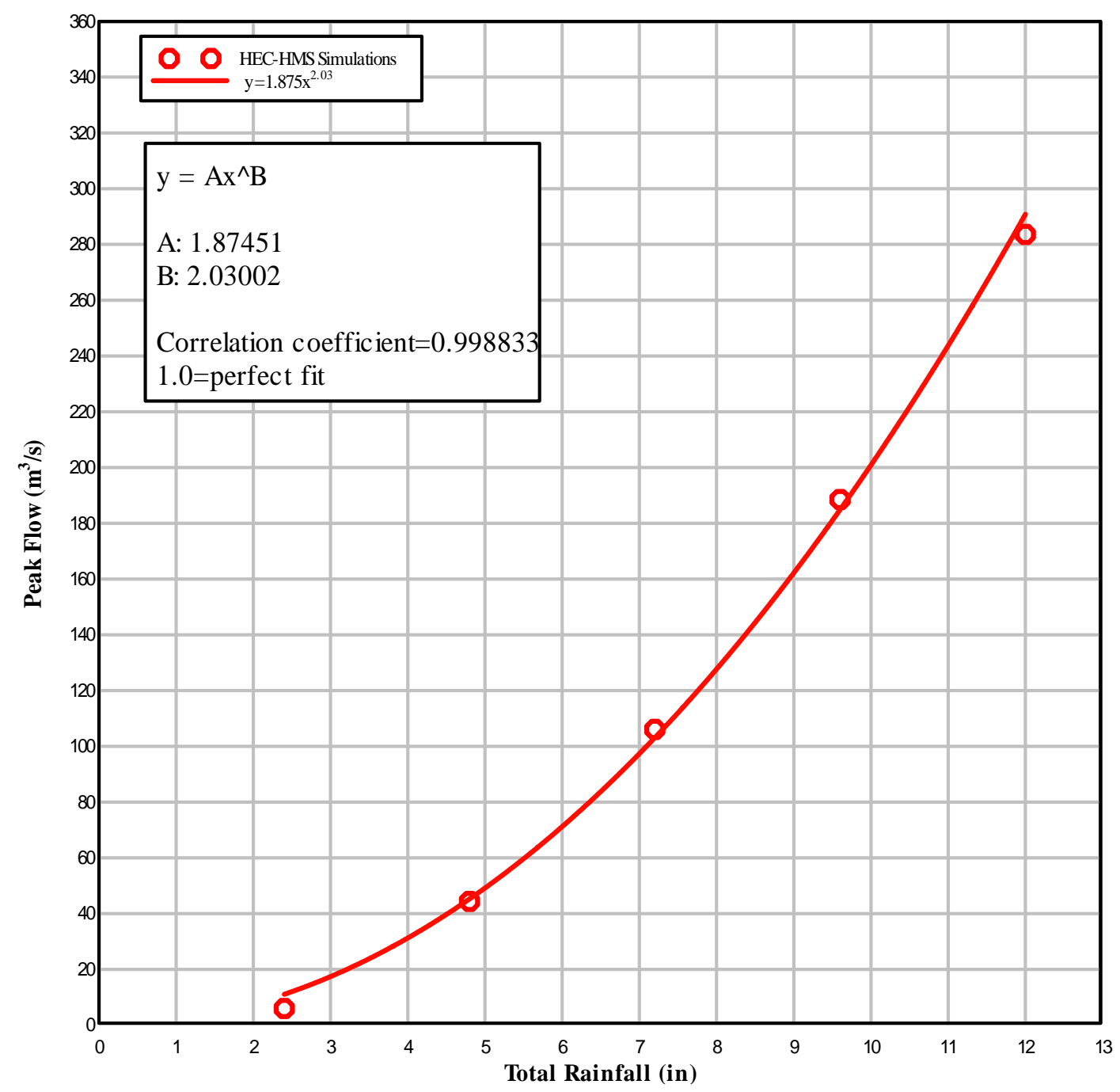


Figure 19

Fourmile Branch Peak Runoff Flow as a Function of Total Rainfall Rainfall Duration = 1 hour

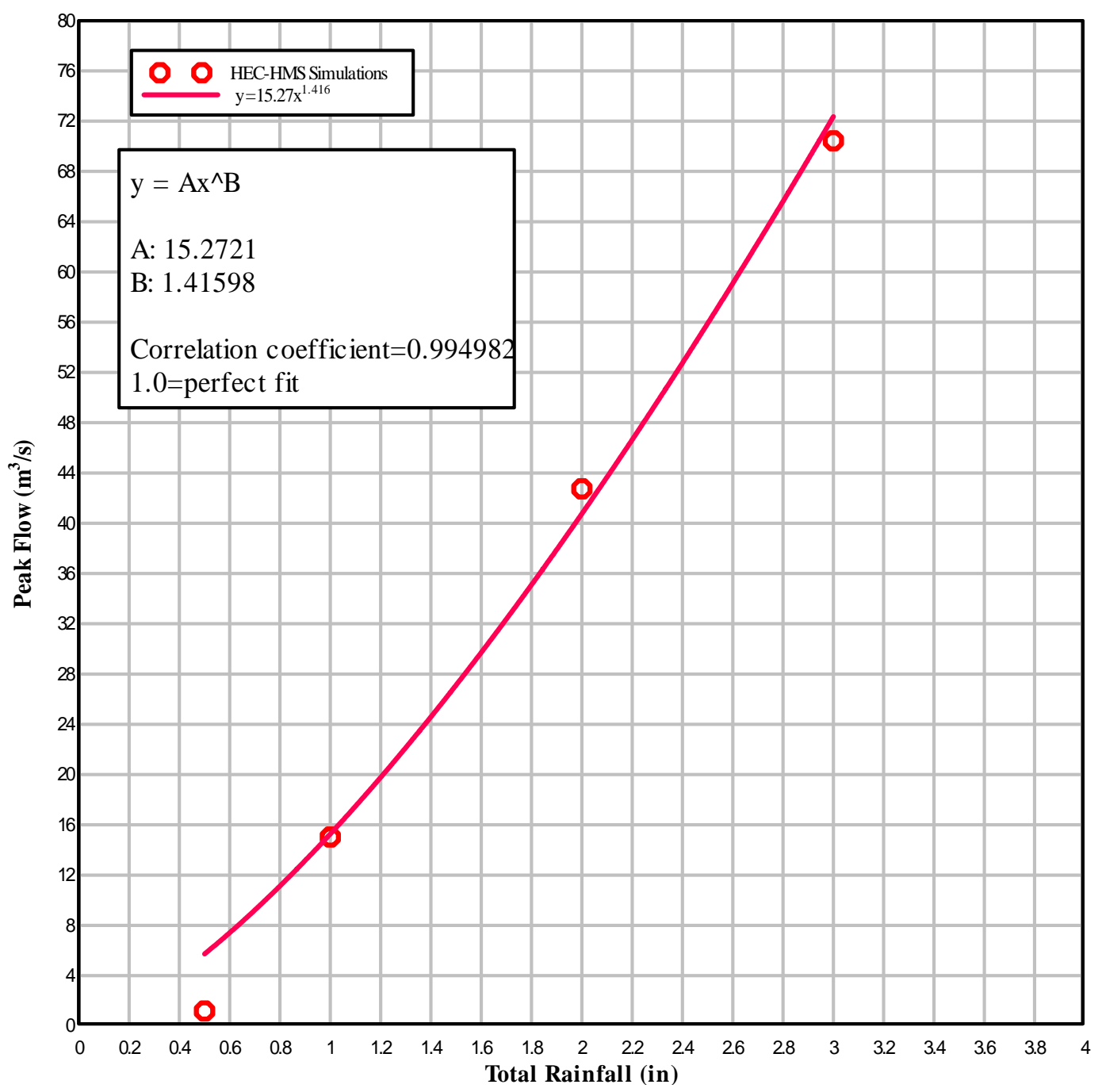


Figure 20

Fourmile Branch Peak Runoff Flow as a Function of Total Rainfall

Rainfall Duration $=\mathbf{3}$ hour

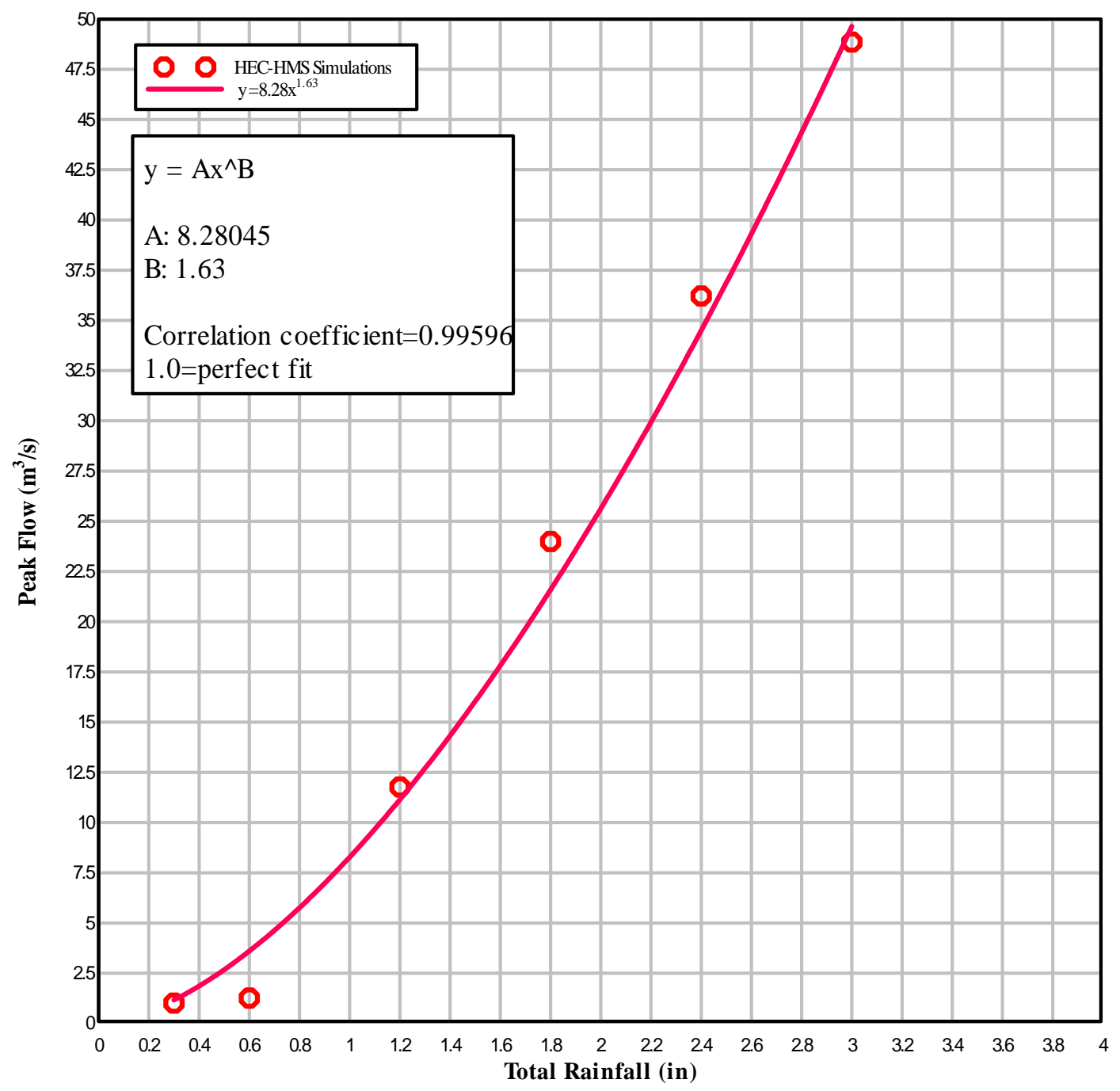


Figure 21

Fourmile Branch Peak Runoff Flow as a Function of Total Rainfall Rainfall Duration $=6$ hours

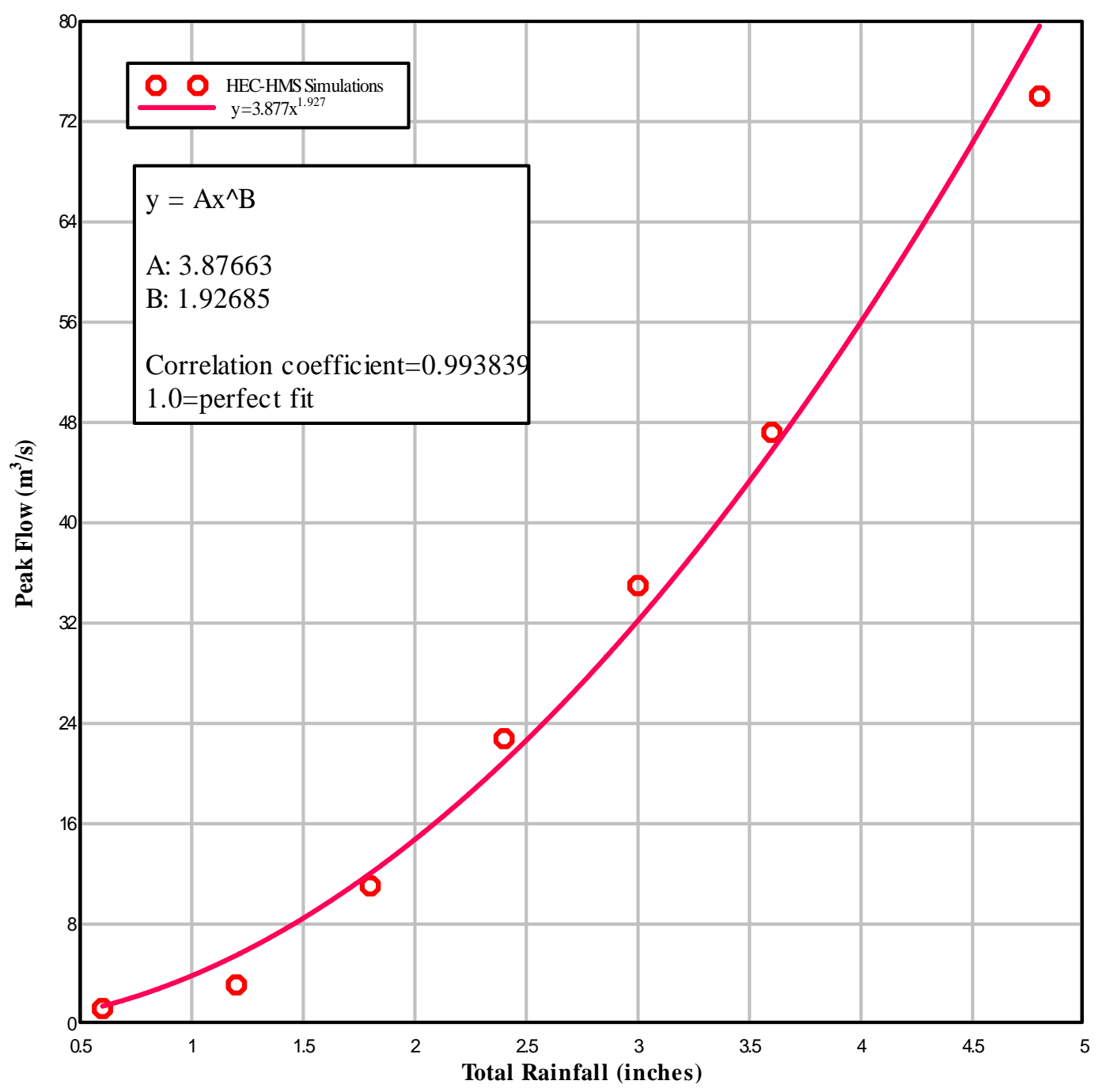


Figure 22

Fourmile Branch Peak Runoff Flow as a Function of Total Rainfall

Rainfall Duration $=12$ hour

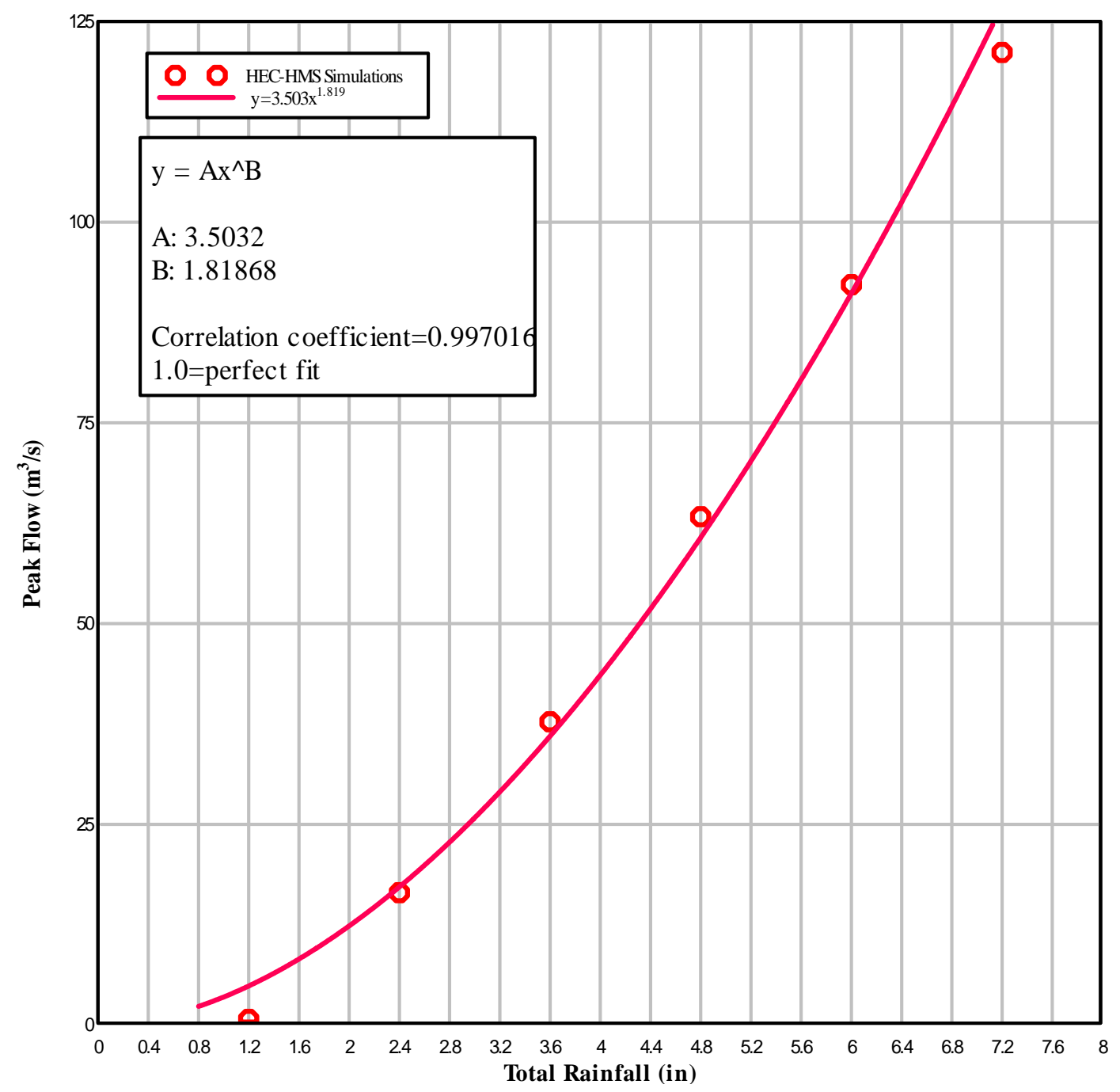


Figure 23

Fourmile Branch Peak Runoff Flow as a Function of Total Rainfall Rainfall Duration $\mathbf{2} \mathbf{2 4}$ hours

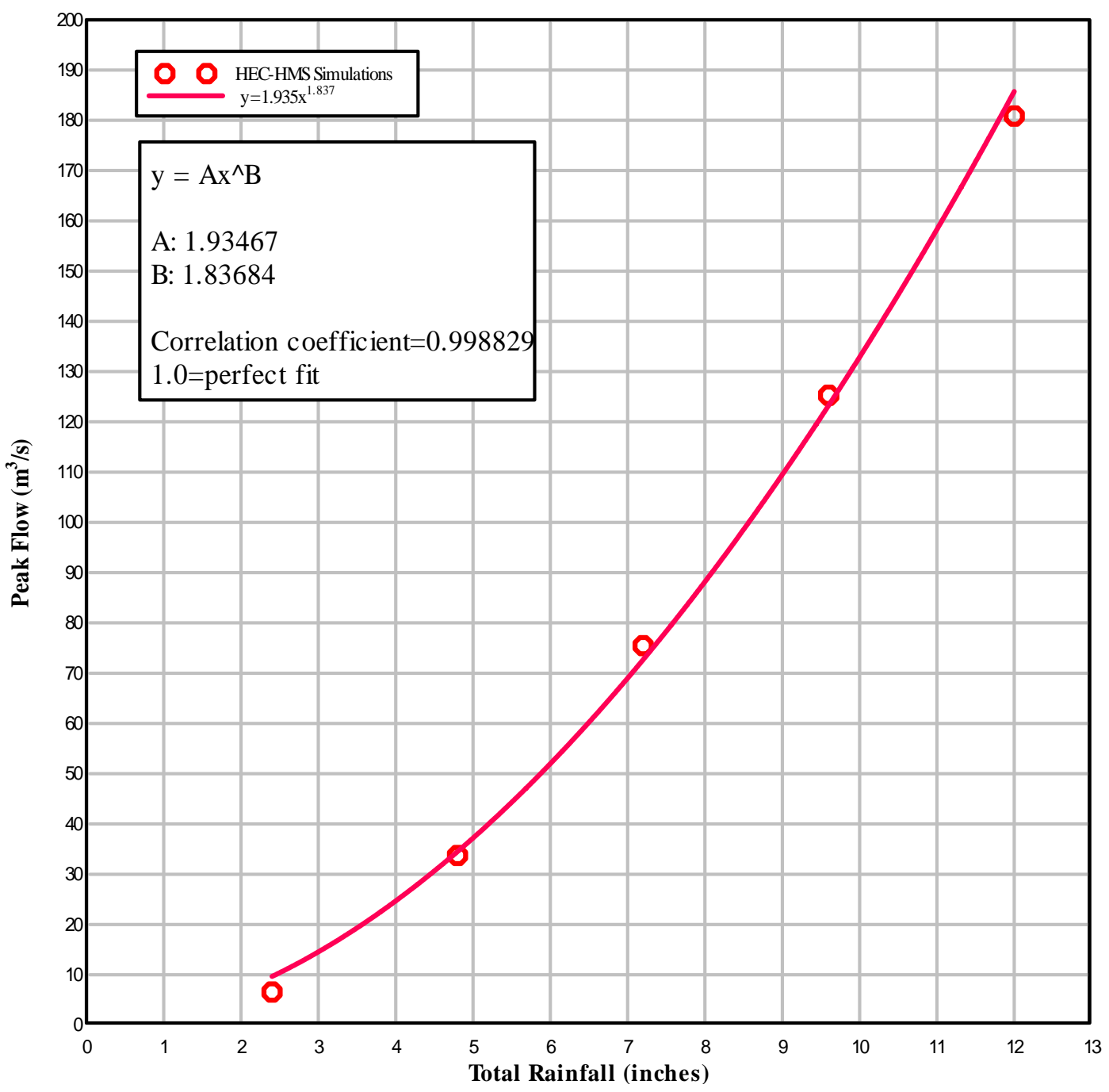


Figure 24

Pen Branch Peak Runoff Flow as a Function of Total Rainfall

Rainfall Duration $=1$ hour

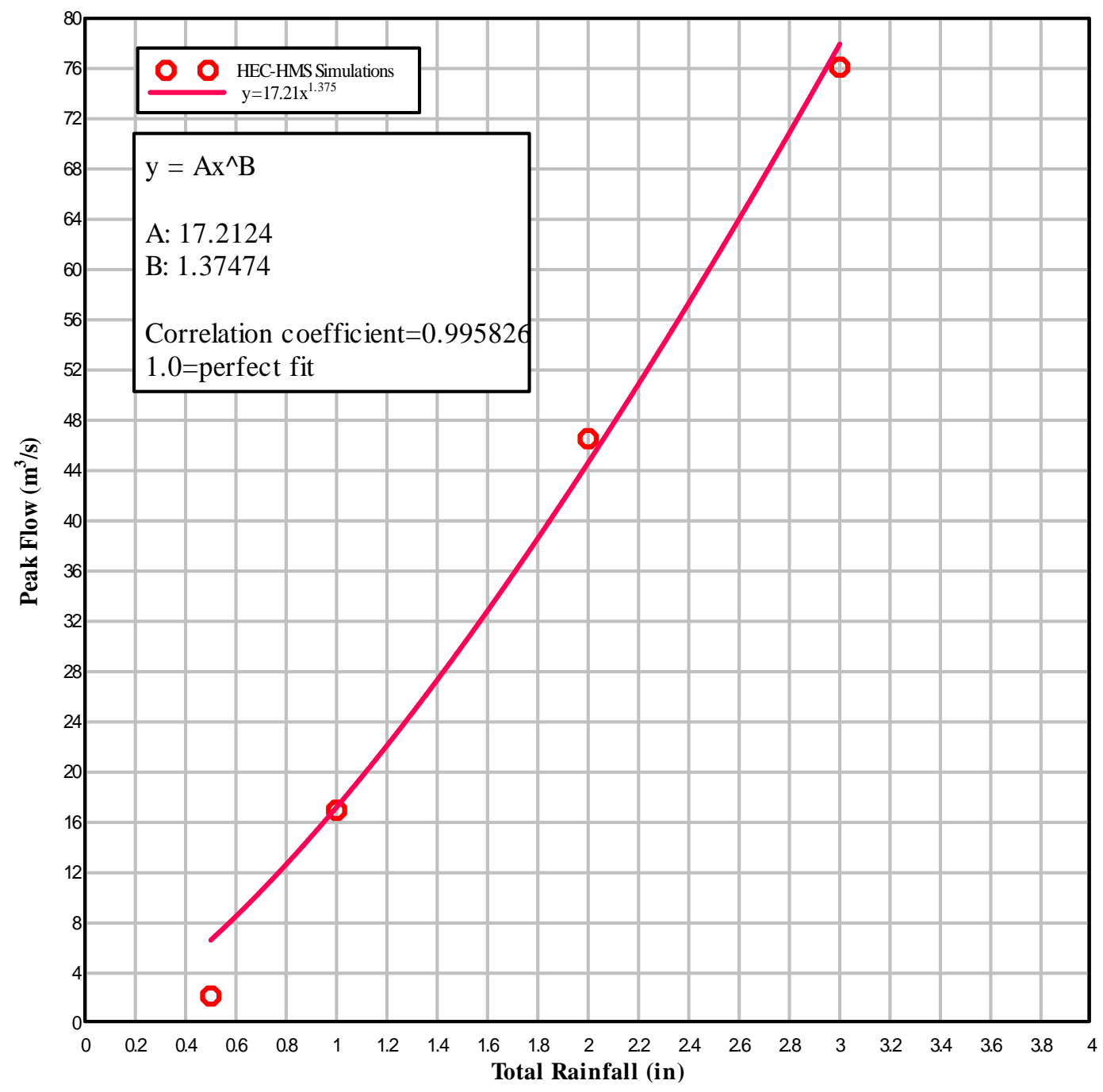


Figure 25

Pen Branch Peak Runoff Flow as a Function of Total Rainfall Rainfall Duration $=\mathbf{3}$ hour

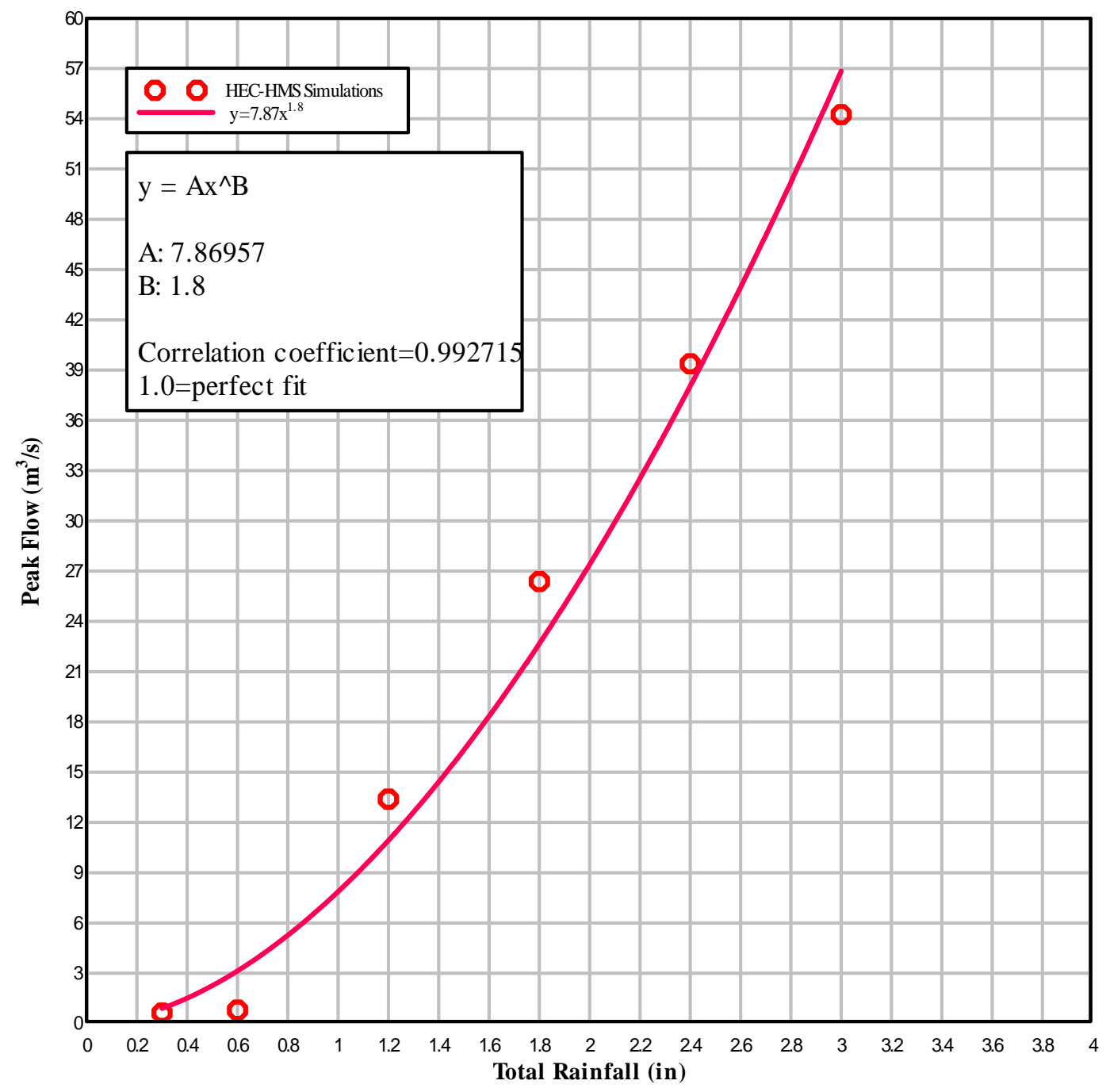


Figure 26

Pen Branch Peak Runoff Flow as a Function of Total Rainfall Rainfall Duration $=6$ hours

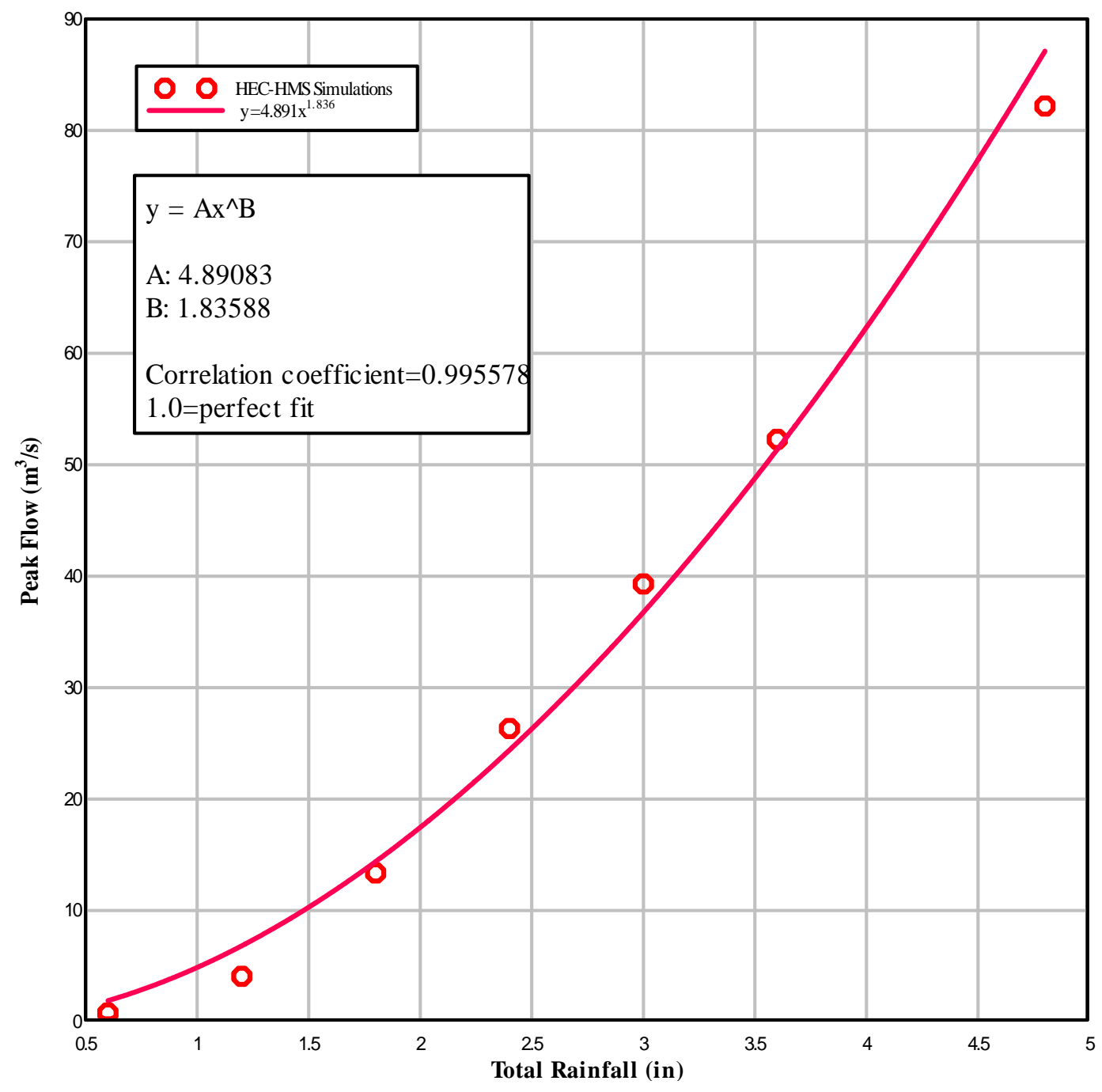


Figure 27

Pen Branch Peak Runoff Flow as a Function of Total Rainfall Rainfall Duration $=12$ hour

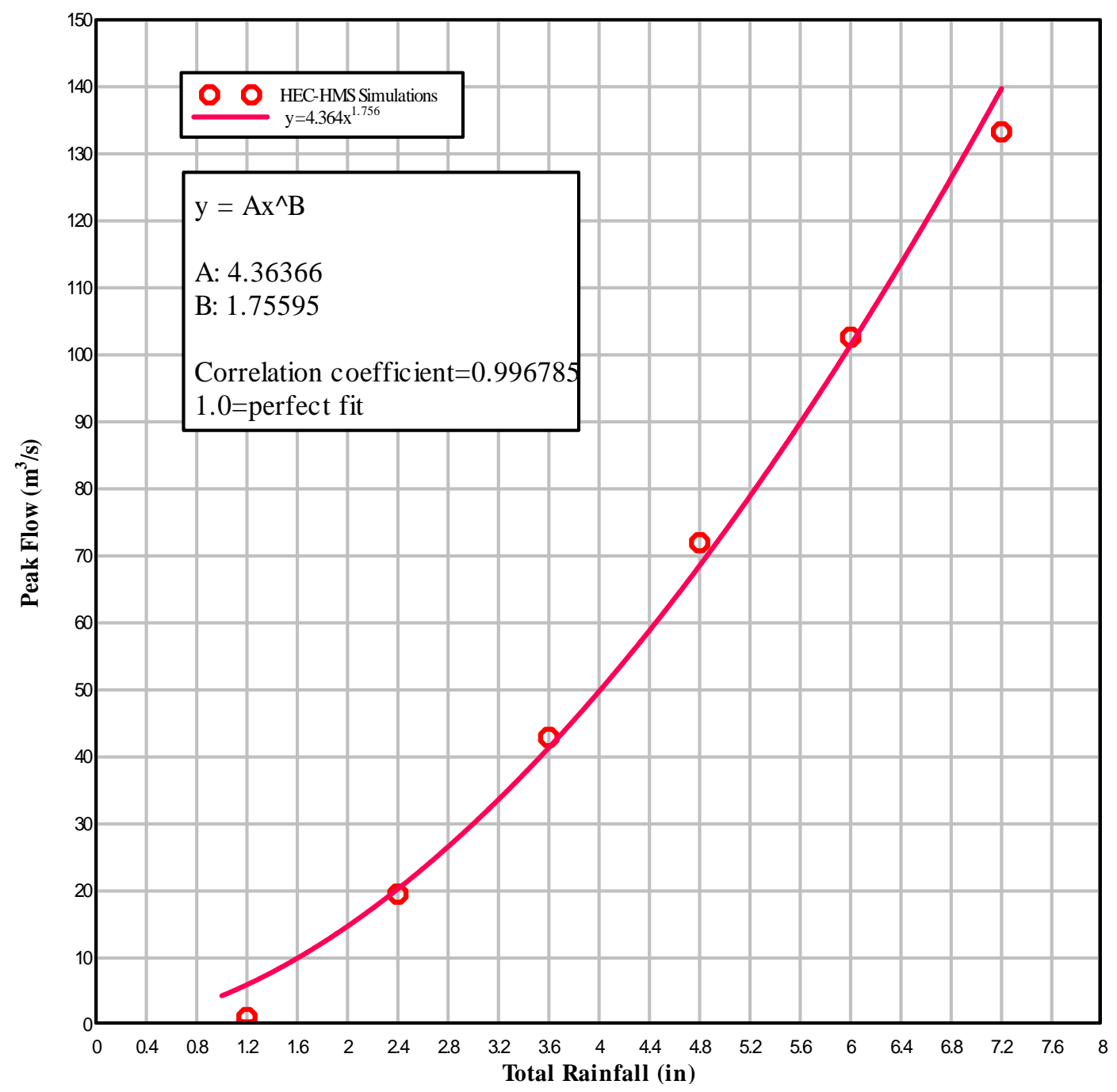


Figure 28

Pen Branch Peak Runoff Flow as a Function of Total Rainfall

Rainfall Duration $=24$ hours

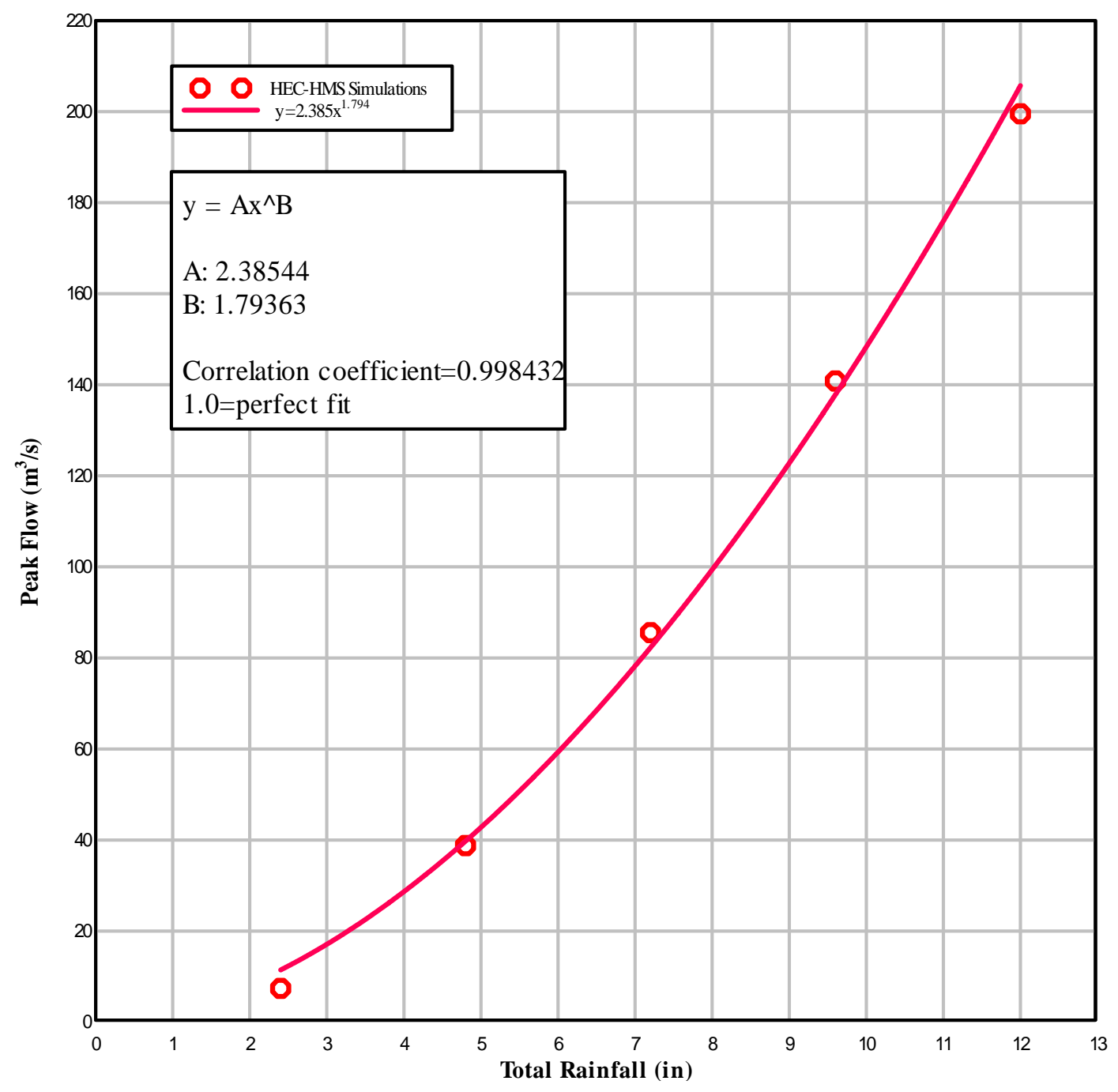


Figure 29

Steel Creek Peak Runoff Flow as a Function of Total Rainfall Rainfall Duration $=1$ hour

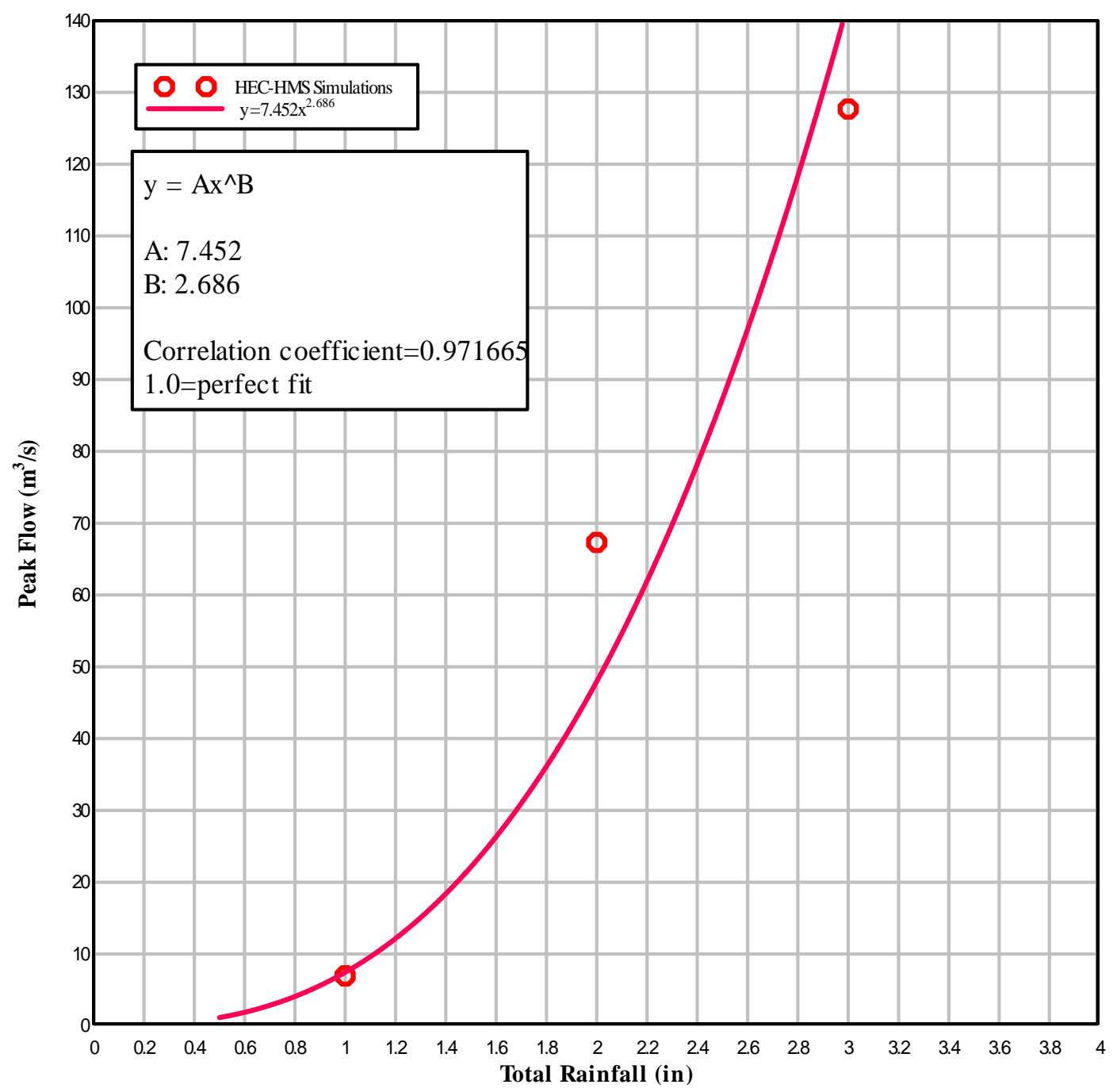


Figure 30

Steel Creek Peak Runoff Flow as a Function of Total Rainfall Rainfall Duration $=\mathbf{3}$ hour

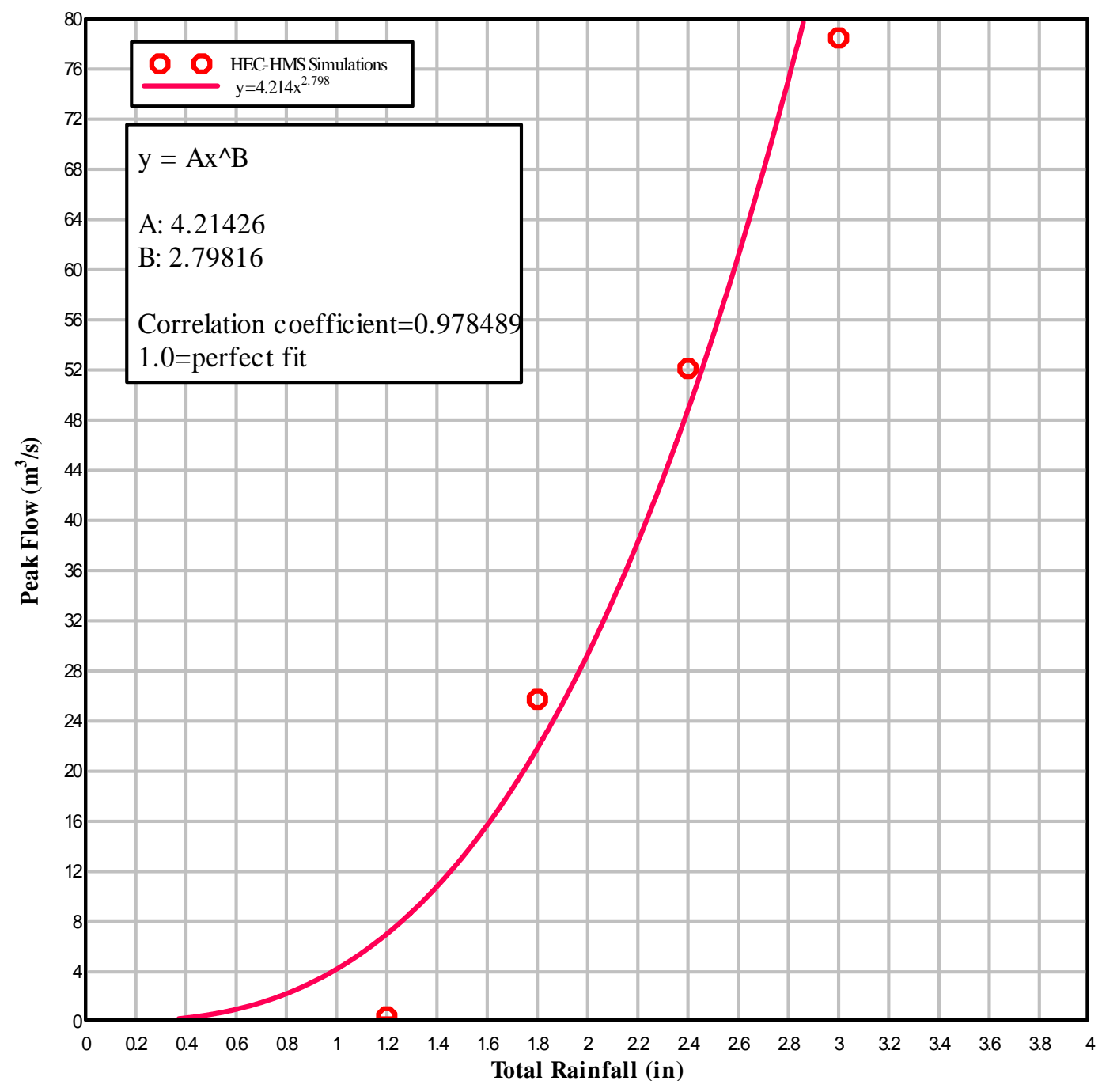


Figure 31

Steel Creek Peak Runoff Flow as a Function of Total Rainfall Rainfall Duration $=6$ hours

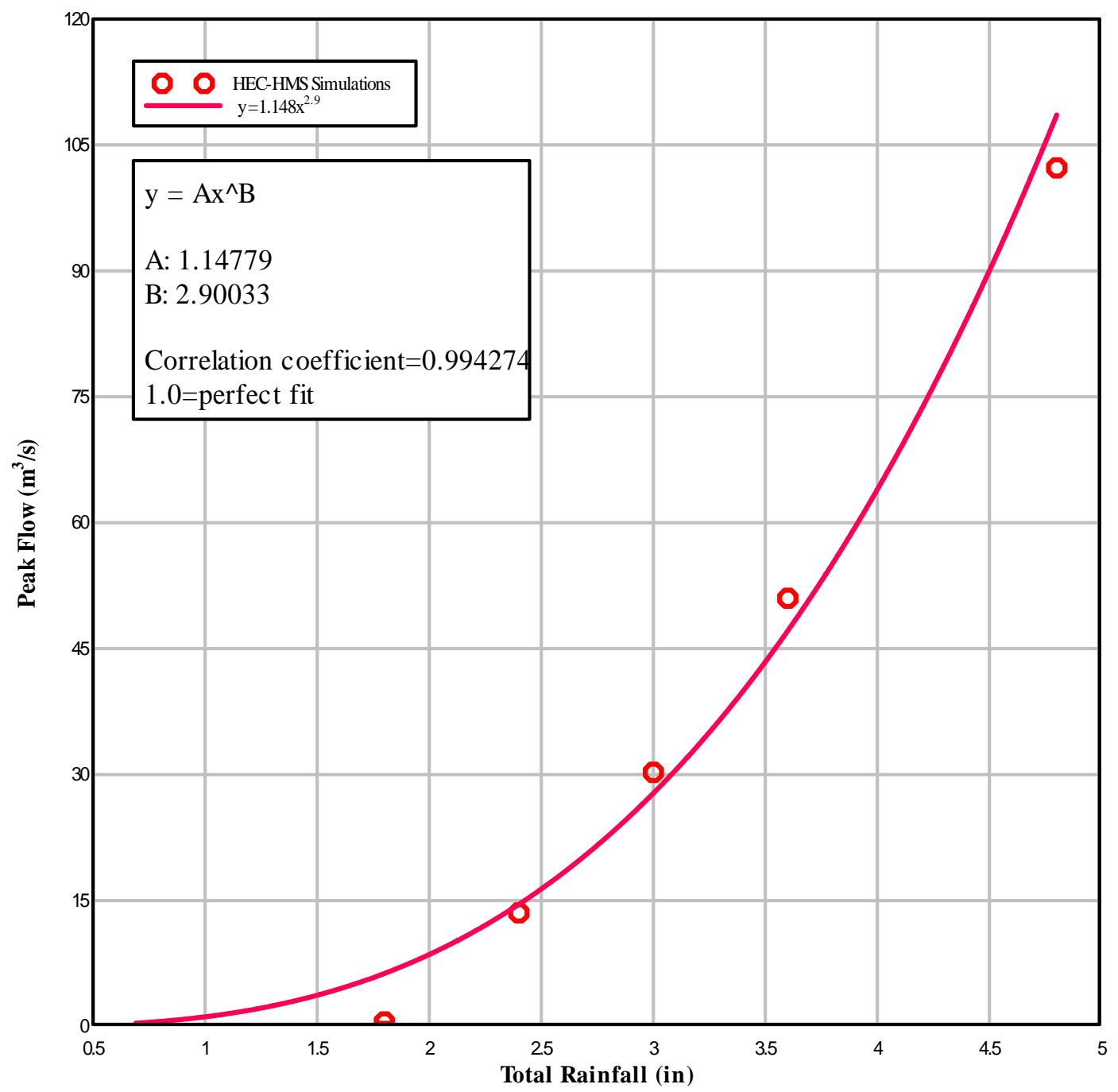


Figure 32

Steel Creek Peak Runoff Flow as a Function of Total Rainfall Rainfall Duration $=12$ hour

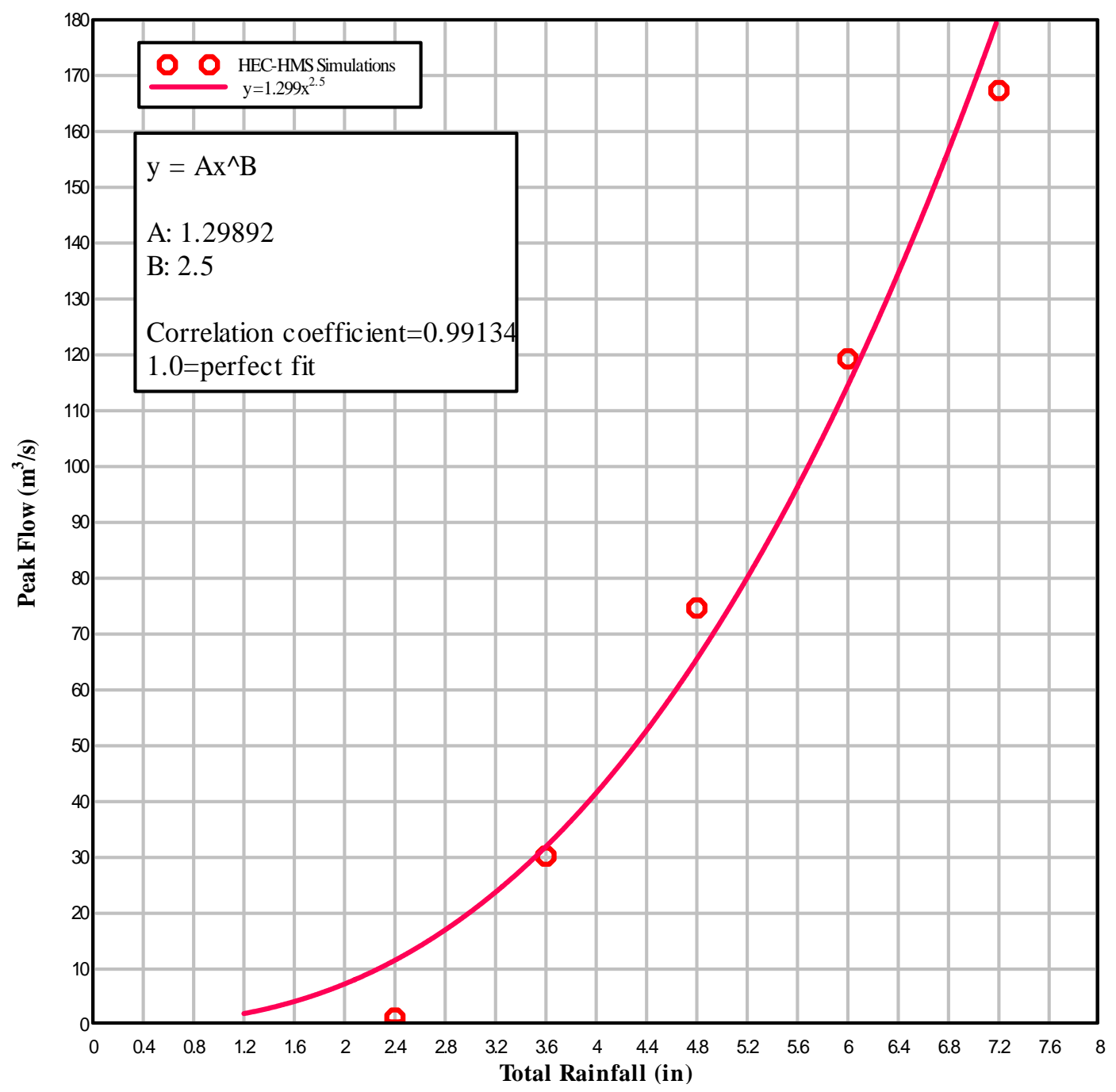


Figure 33

Steel Creek Peak Runoff Flow as a Function of Total Rainfall

Rainfall Duration $=\mathbf{2 4}$ hours

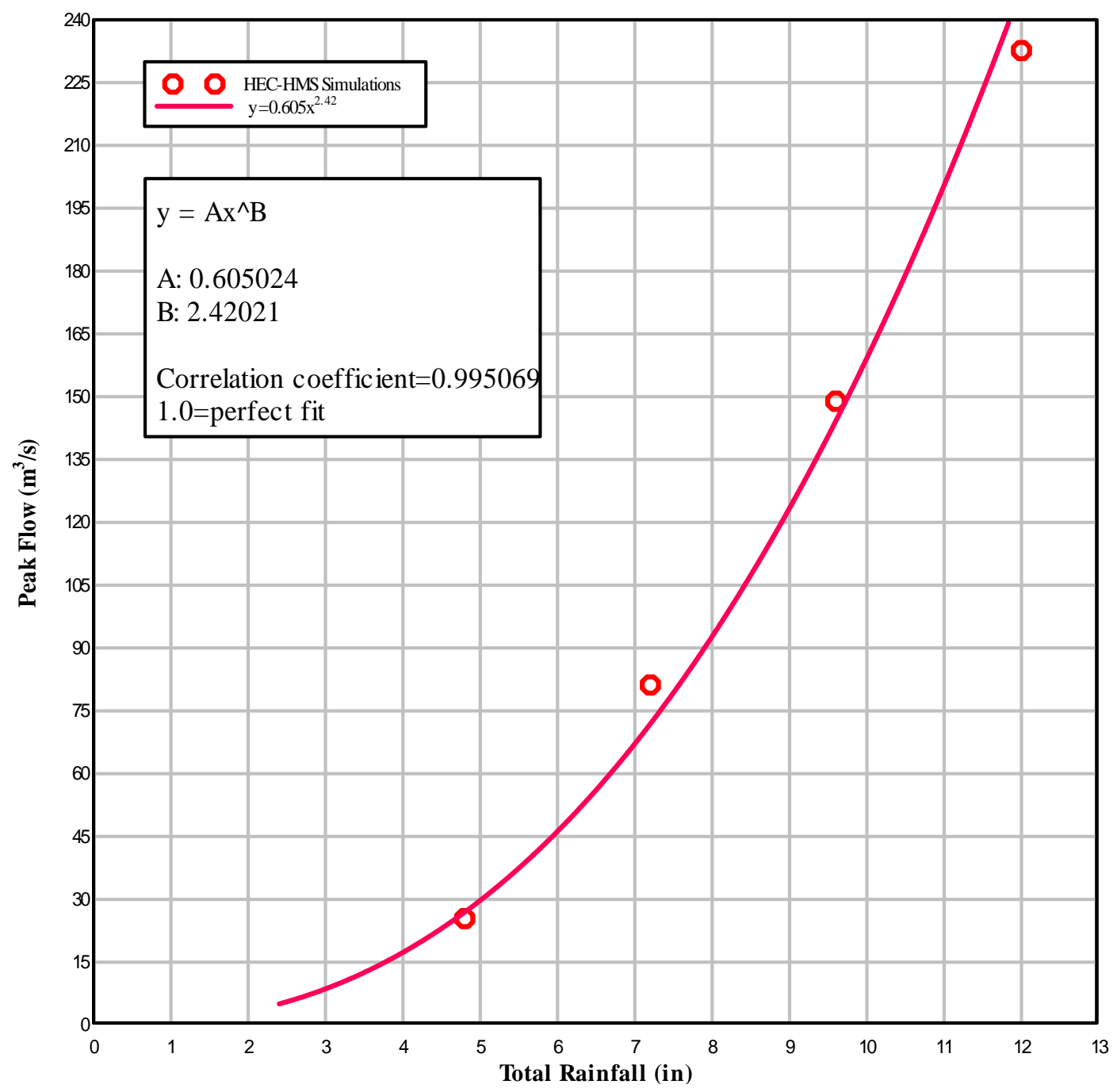


Figure 34

Lower Three Runs Peak Runoff Flow as a Function of Total Rainfall Rainfall Duration $=1$ hour

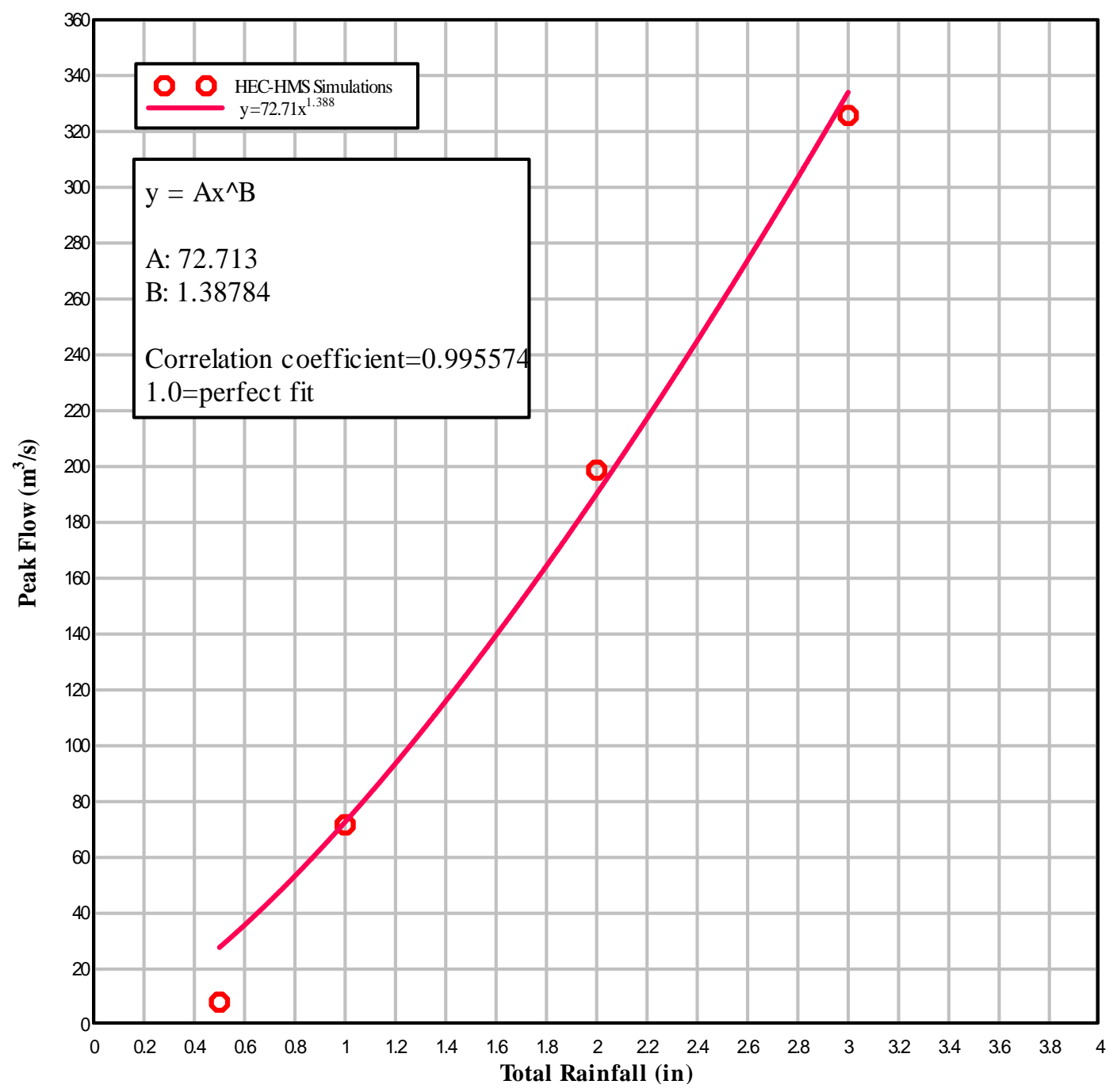


Figure 35

Lower Three Runs Peak Runoff Flow as a Function of Total Rainfall Rainfall Duration $=\mathbf{3}$ hour

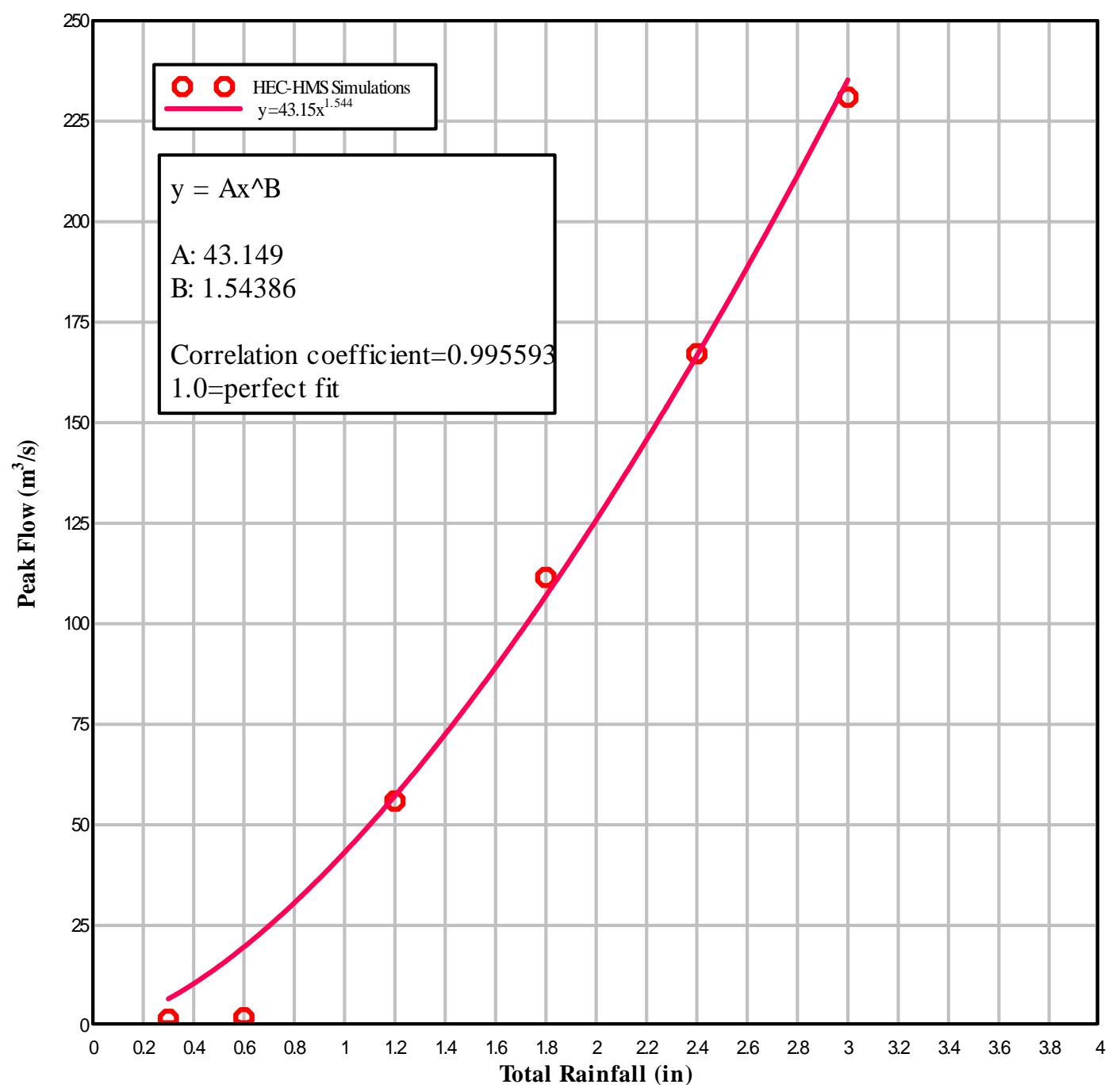


Figure 36

Lower Three Runs Peak Runoff Flow as a Function of Total Rainfall Rainfall Duration $=6$ hours

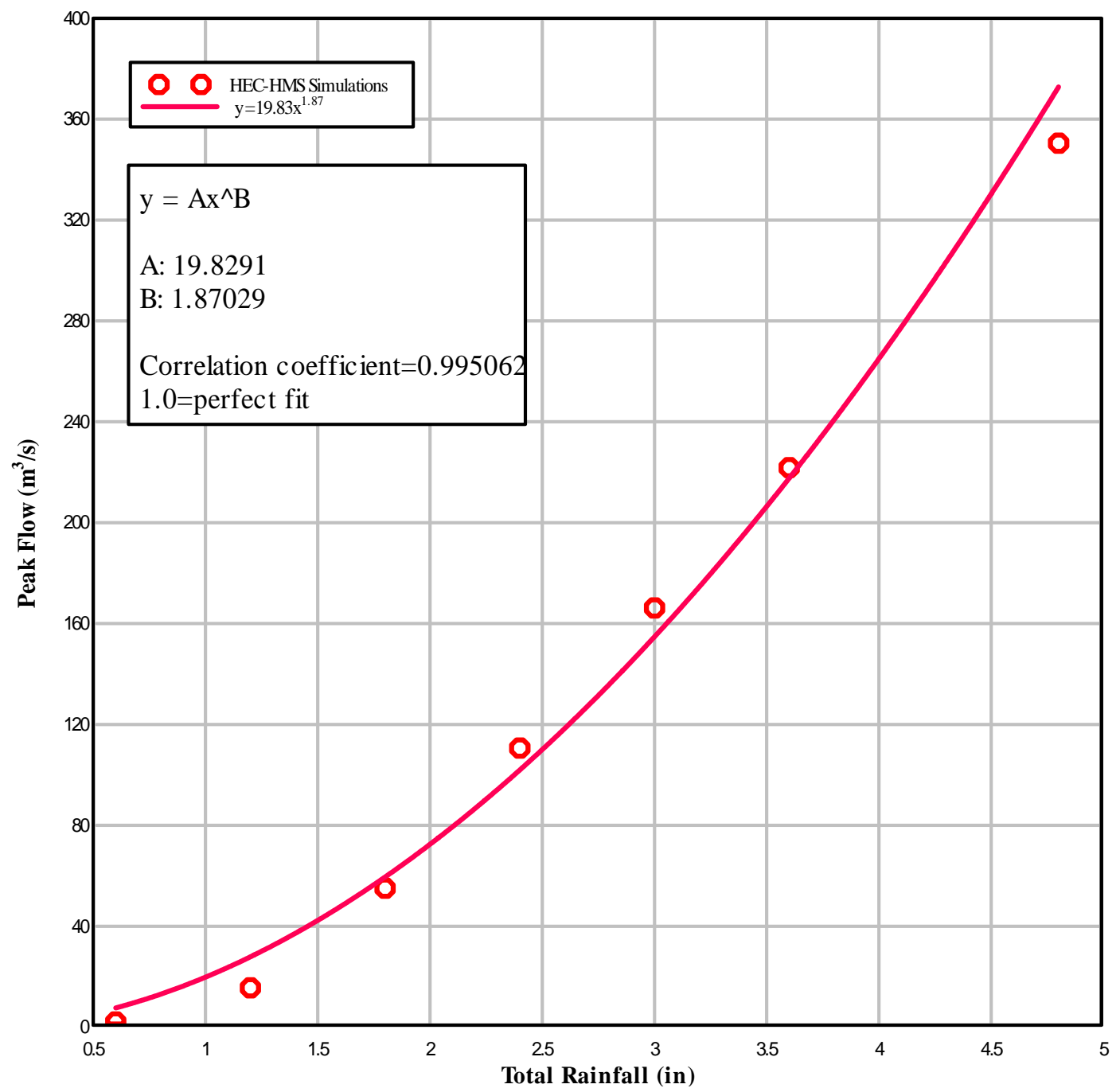


Figure 37

Lower Three Runs Peak Runoff Flow as a Function of Total Rainfall Rainfall Duration $=12$ hour

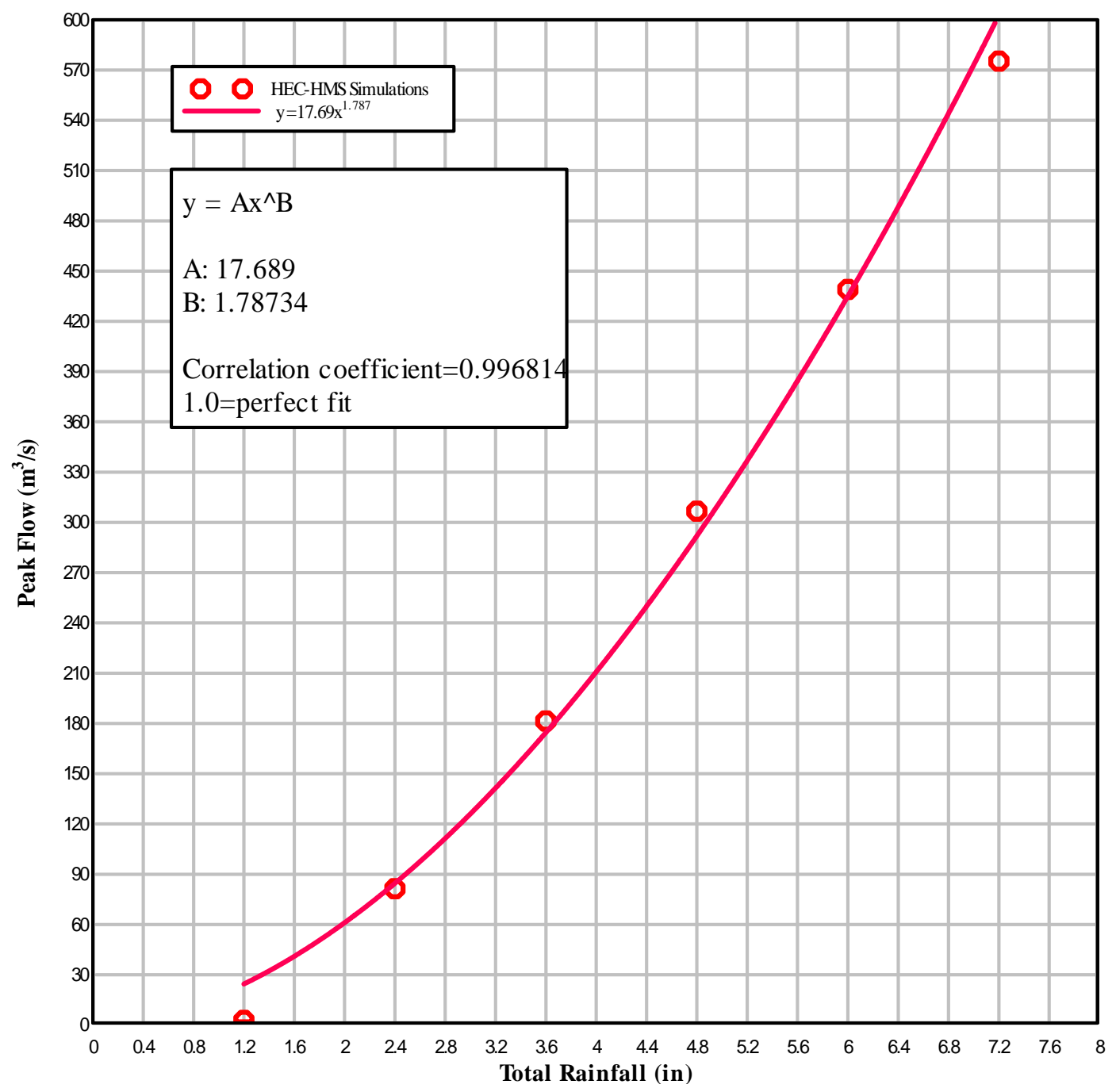


Figure 38

Lower Three Runs Peak Runoff Flow as a Function of Total Rainfall Rainfall Duration $=\mathbf{2 4}$ hours

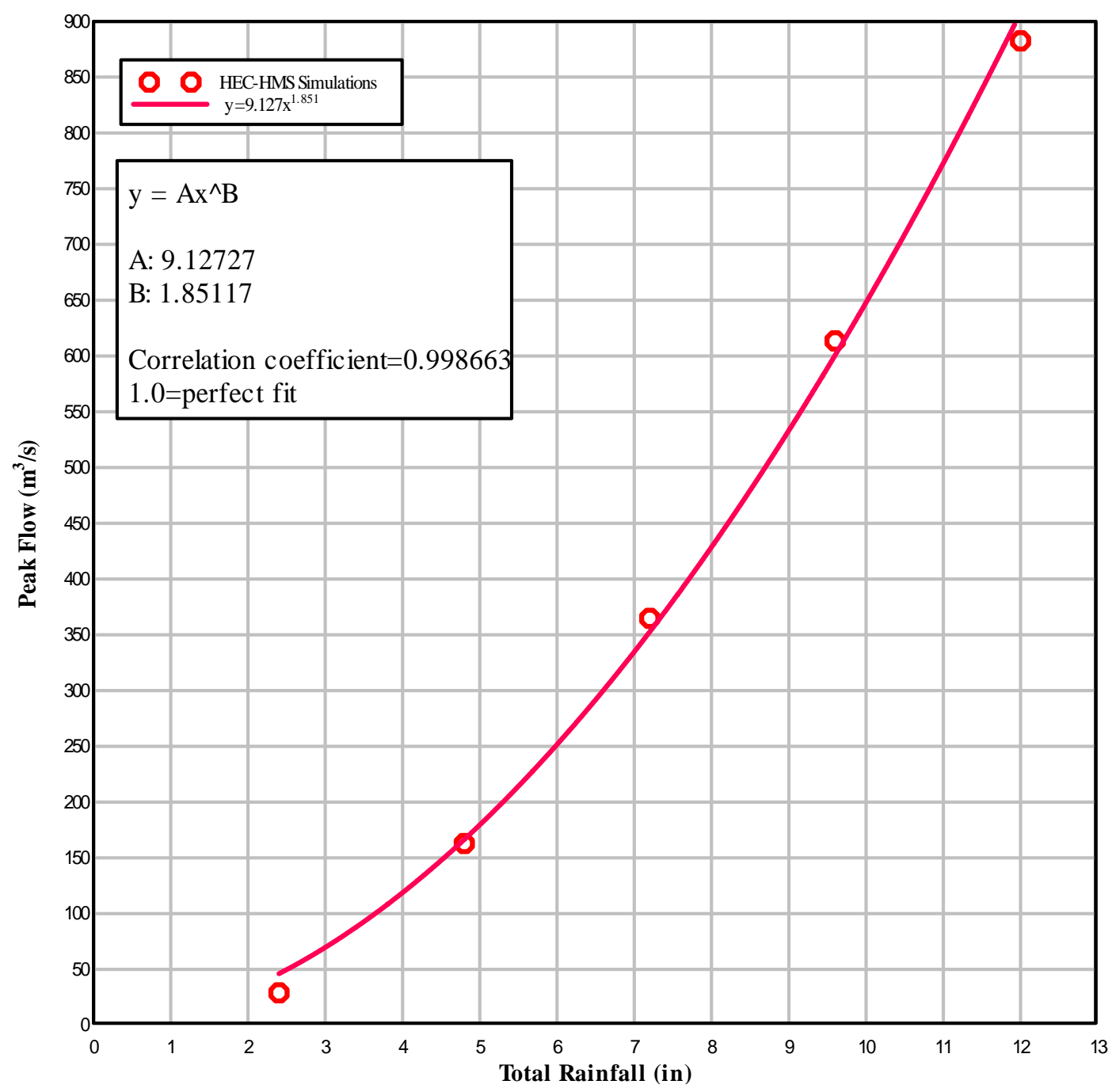


Figure 39

Calculated Upper Three Runs Segment Volume as a Function of Flow Segment Size: 500 Meters

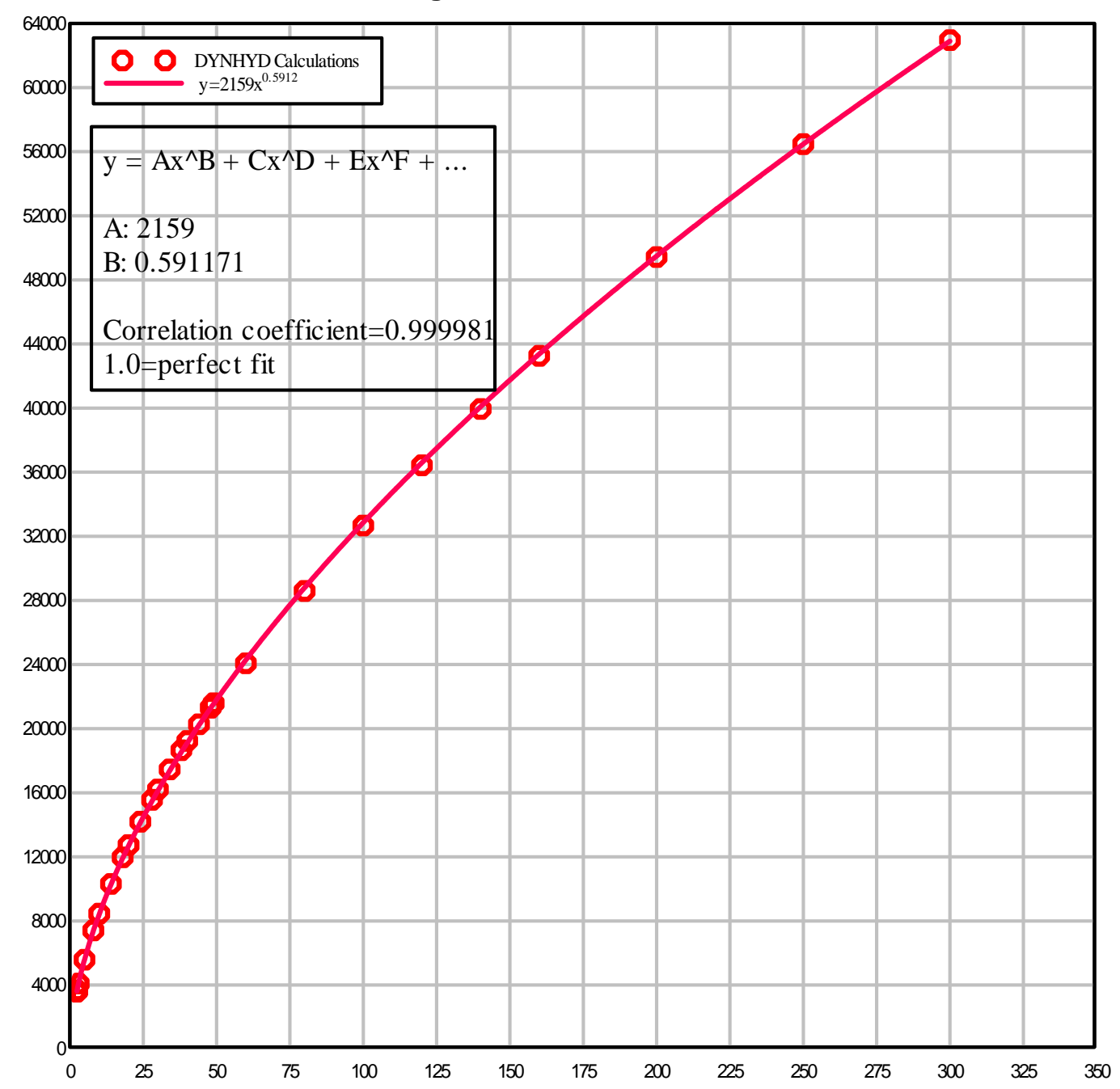


Figure 40

Calculated McQueen Branch Segment Volume as a Function of Flow

Segment Size: 500 Meters

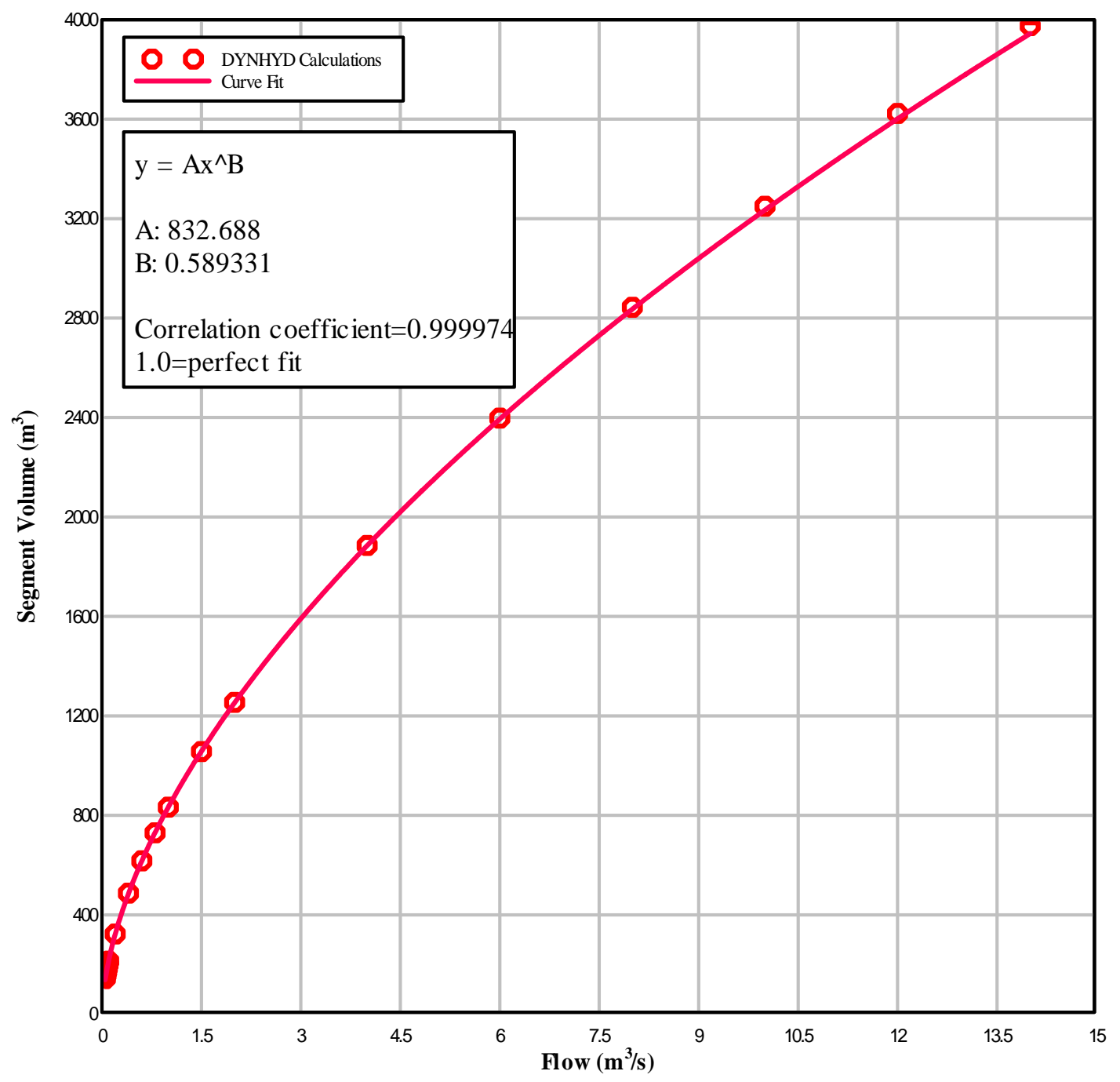


Figure 41

Calculated Tims Branch Segment Volume as a Function of Flow

Segment Size: 500 Meters

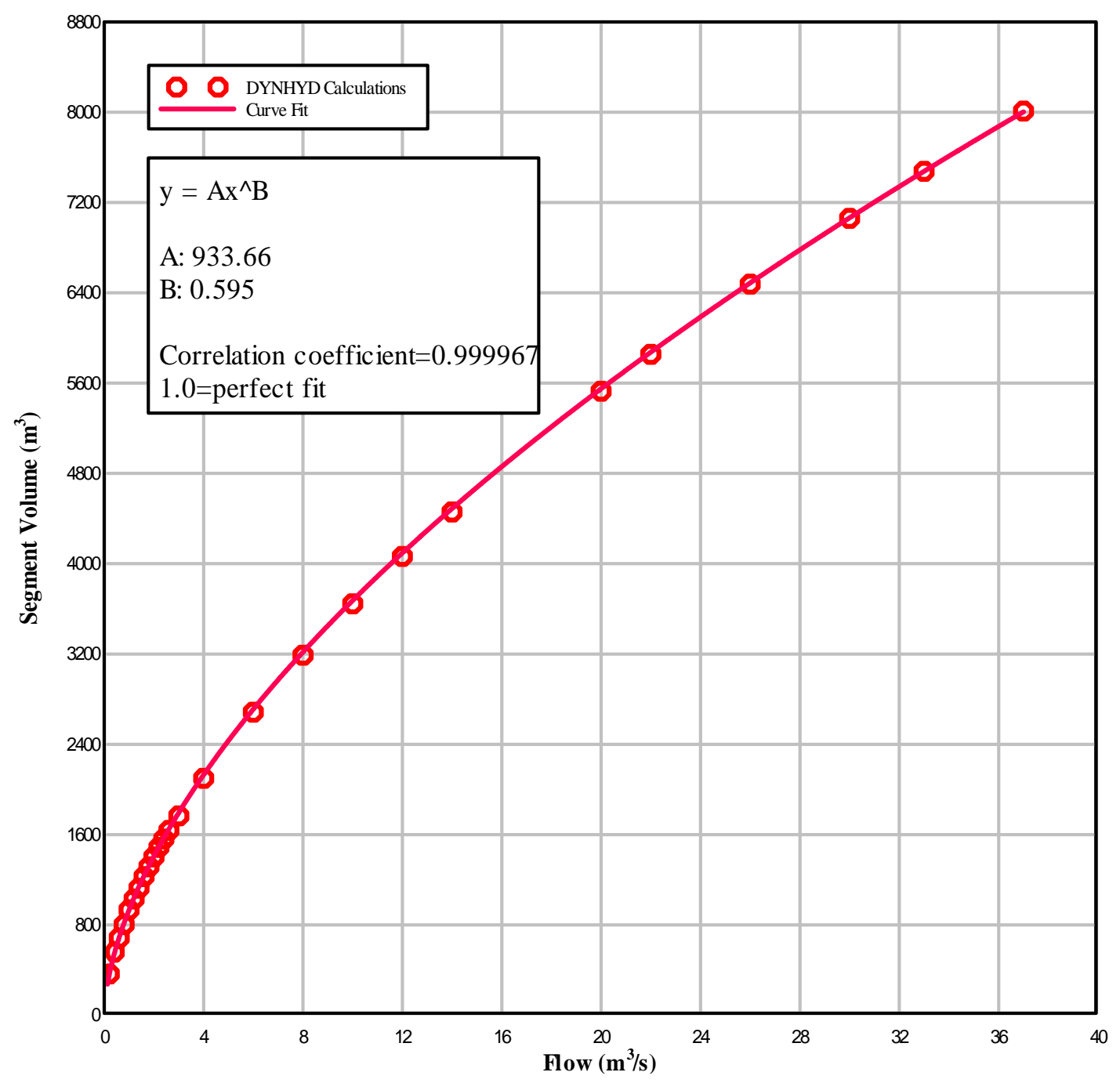


Figure 42

Calculated Fourmile Branch Segment Volume as a Function of Flow Segment Size: 150 Meters

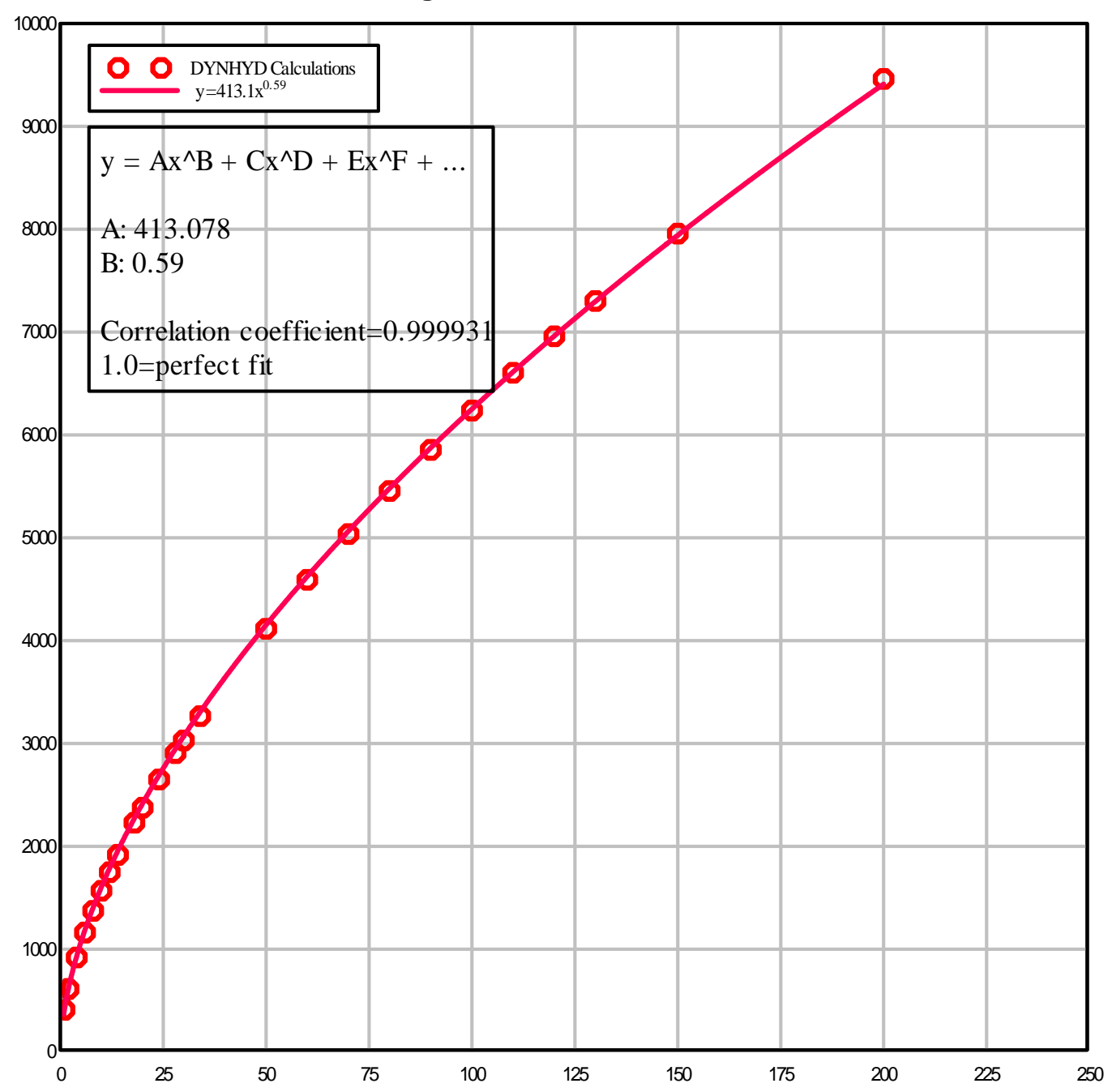


Figure 43

CalculatedPen Branch Segment Volume as a Function of Flow

Segment Size: 500 Meters

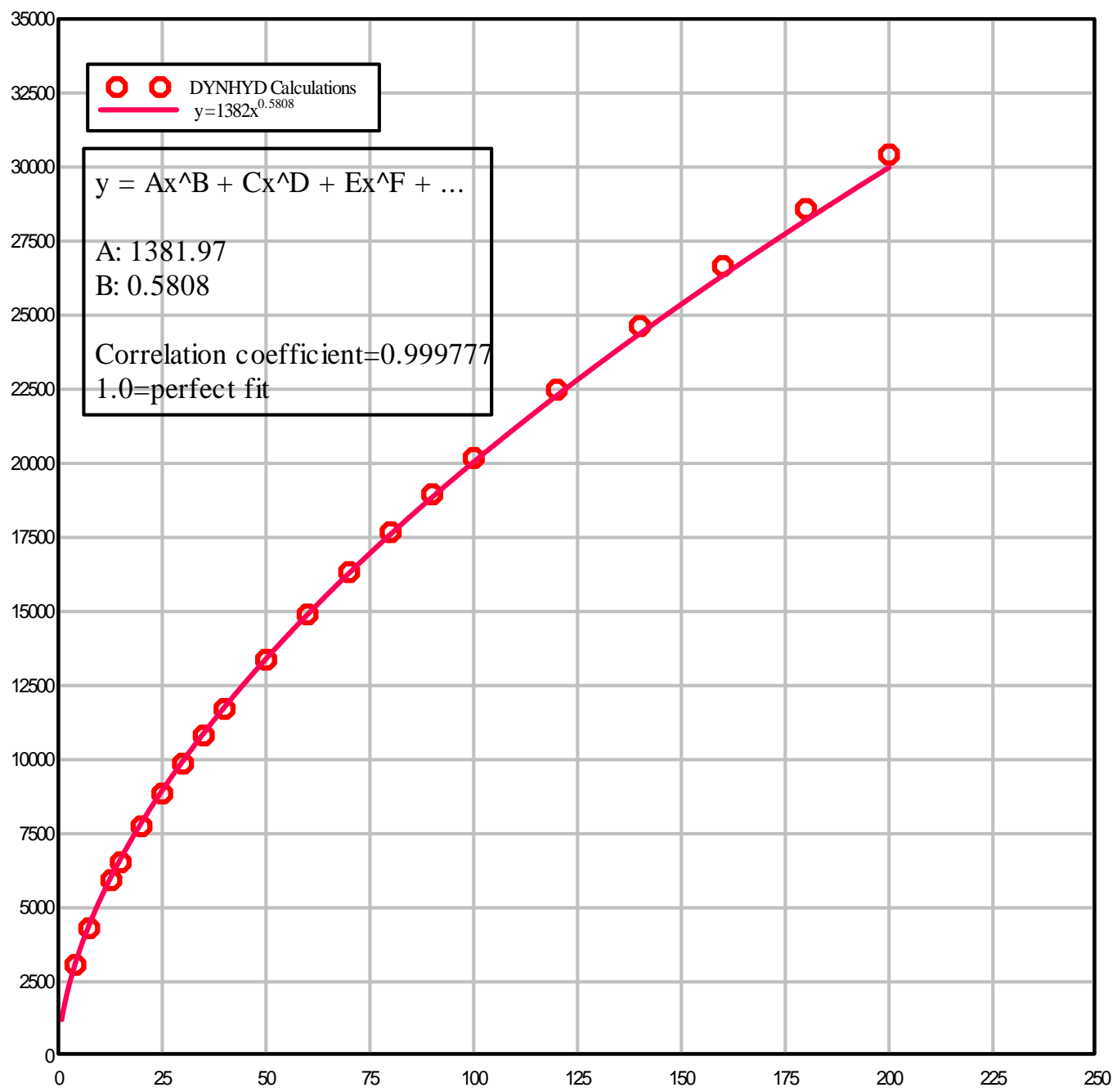


Figure 44

Calculated Steel Creek Segment Volume as a Function of Flow Segment Size: 500 Meters

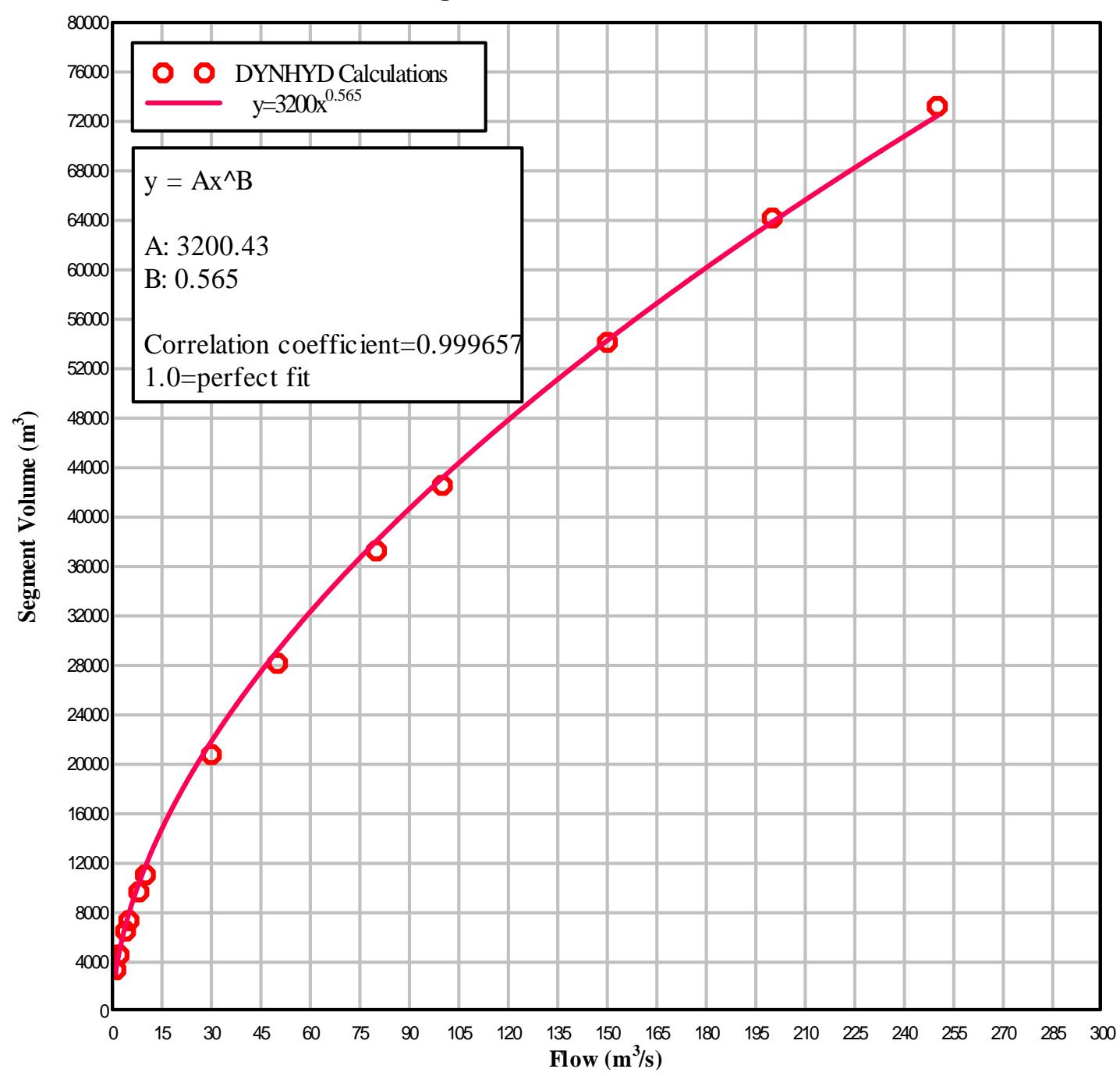


Figure 45

Calculated Lower Three Runs Segment Volume as a Function of Flow Segment Size: 500 Meters

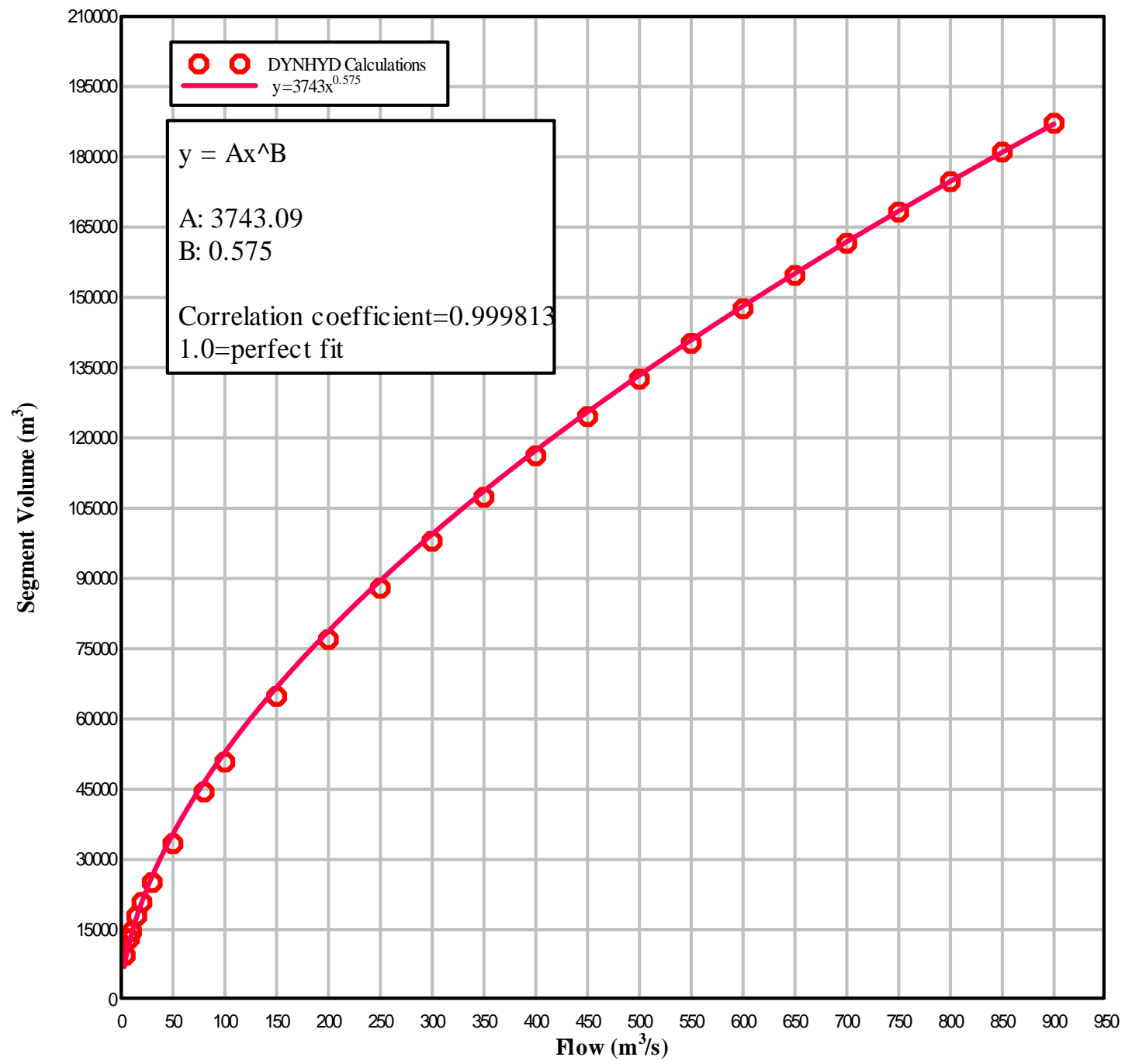


Figure 46

Calculated Savannah River Segment Volume as a Function of Flow Segment Size: 500 meters

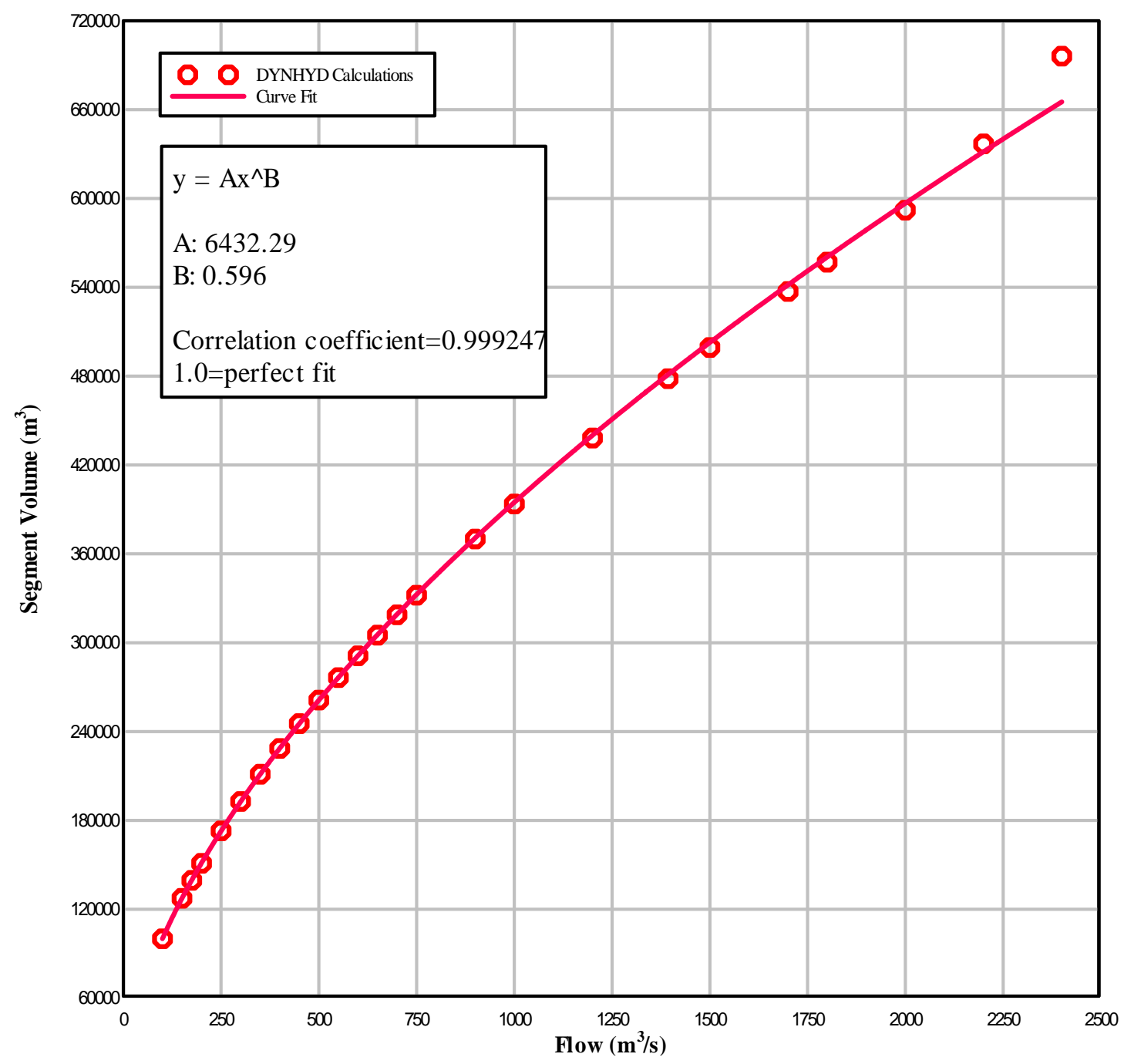


Figure 47 STREAM II-V5 Graphical User Interface

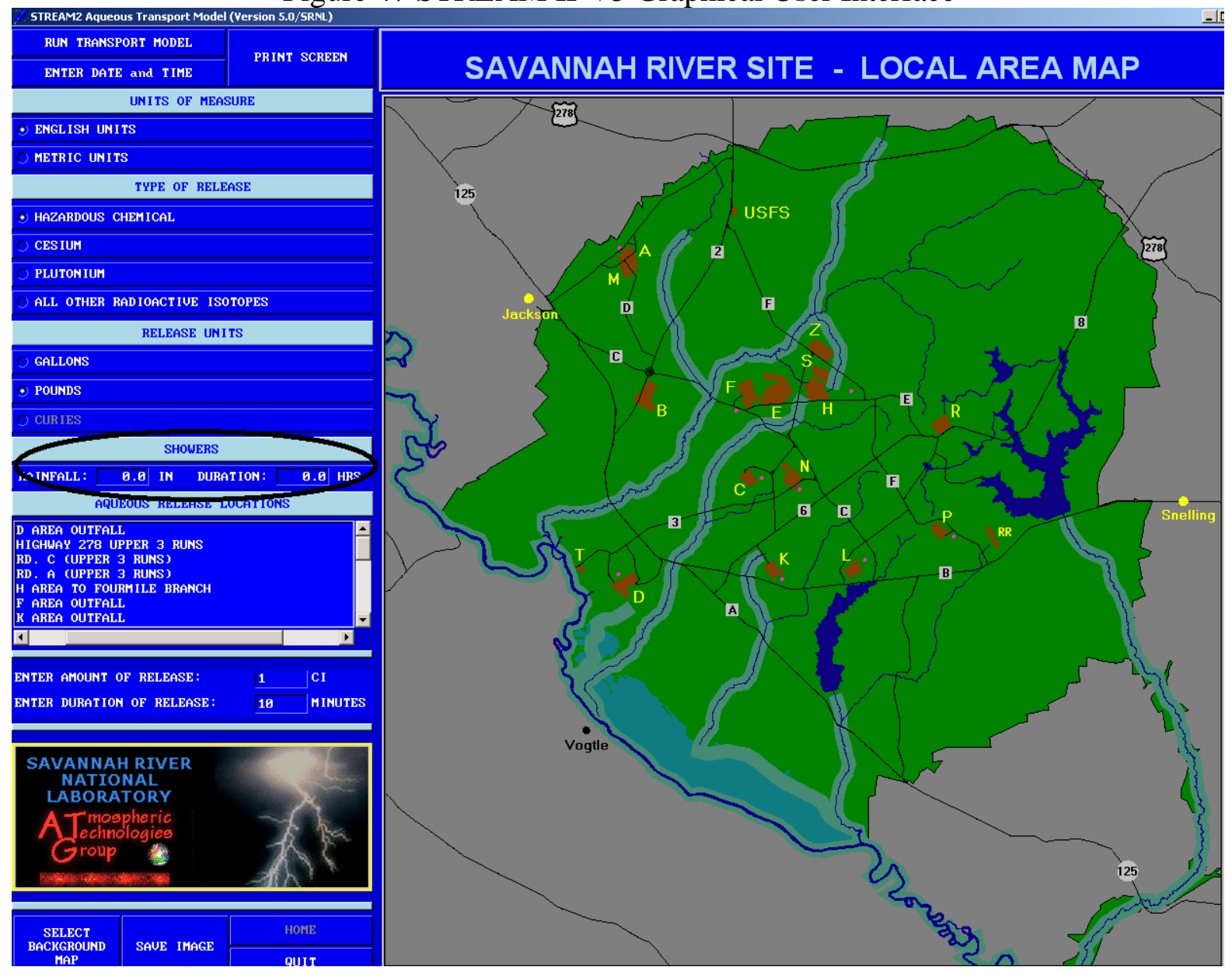


Figure 48

Comparison of Model Predictions for the Peak Concentrations STREAM II-V5 vs STREAM II-V4

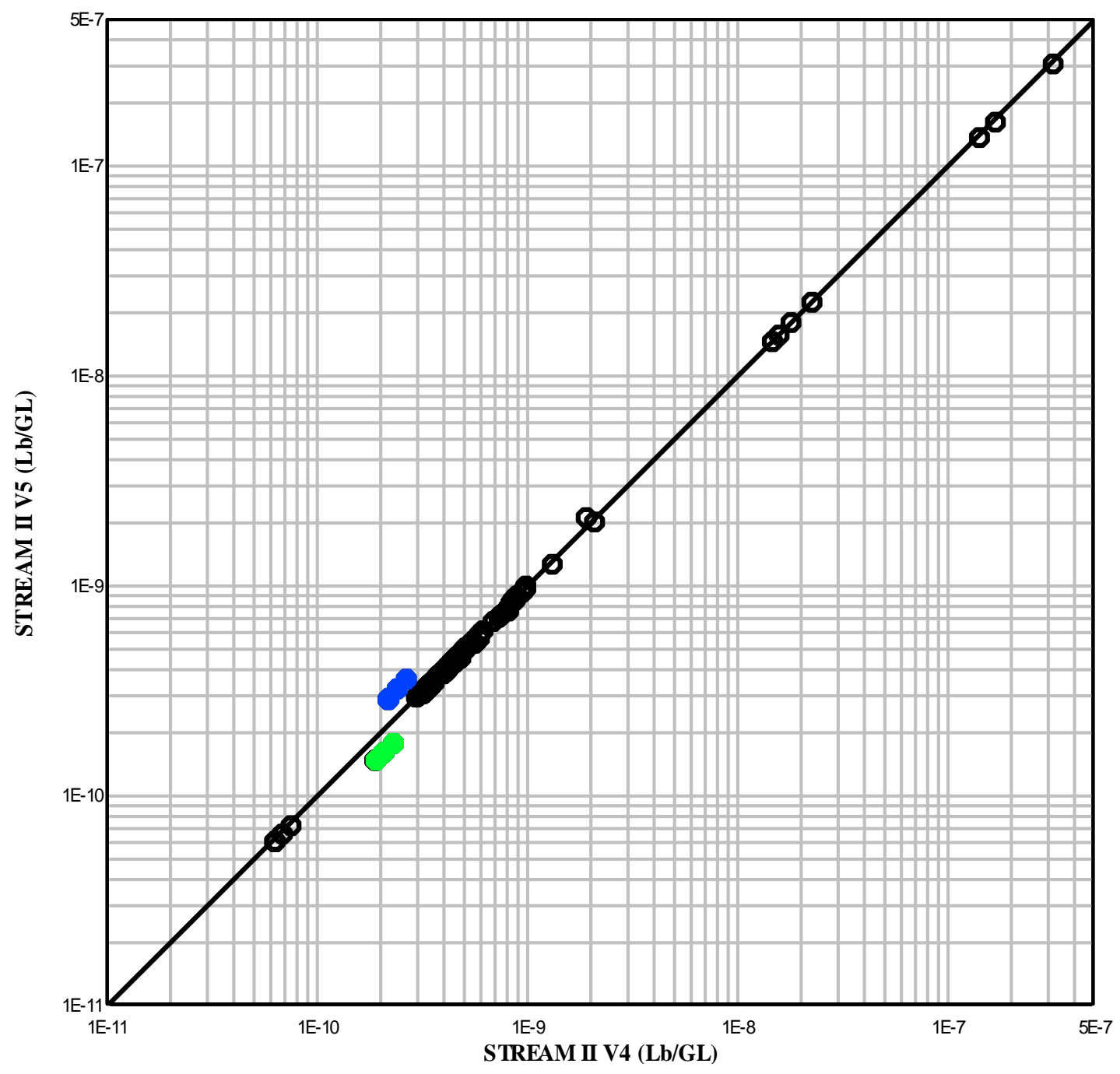

Note:

The green dots represent the simulation results for a release into the Steel Creek, and the blue dots represent the simulation results for a release into the Lower Three Runs. In STREAM II-V5, the segment volumes were varied as a function of flow. However, for STREAM IIV4, the segment volumes were also varied as a function of flow except the Pen Branch, Steel Creek and Lower Three Runs. As a result, predictions of the peak concentrations are not in good agreement between these two versions. 
Figure 49

Comparison of Model Predictions for the Peak Concentration Arrival Time STREAM II-V5 vs STREAM II-V4

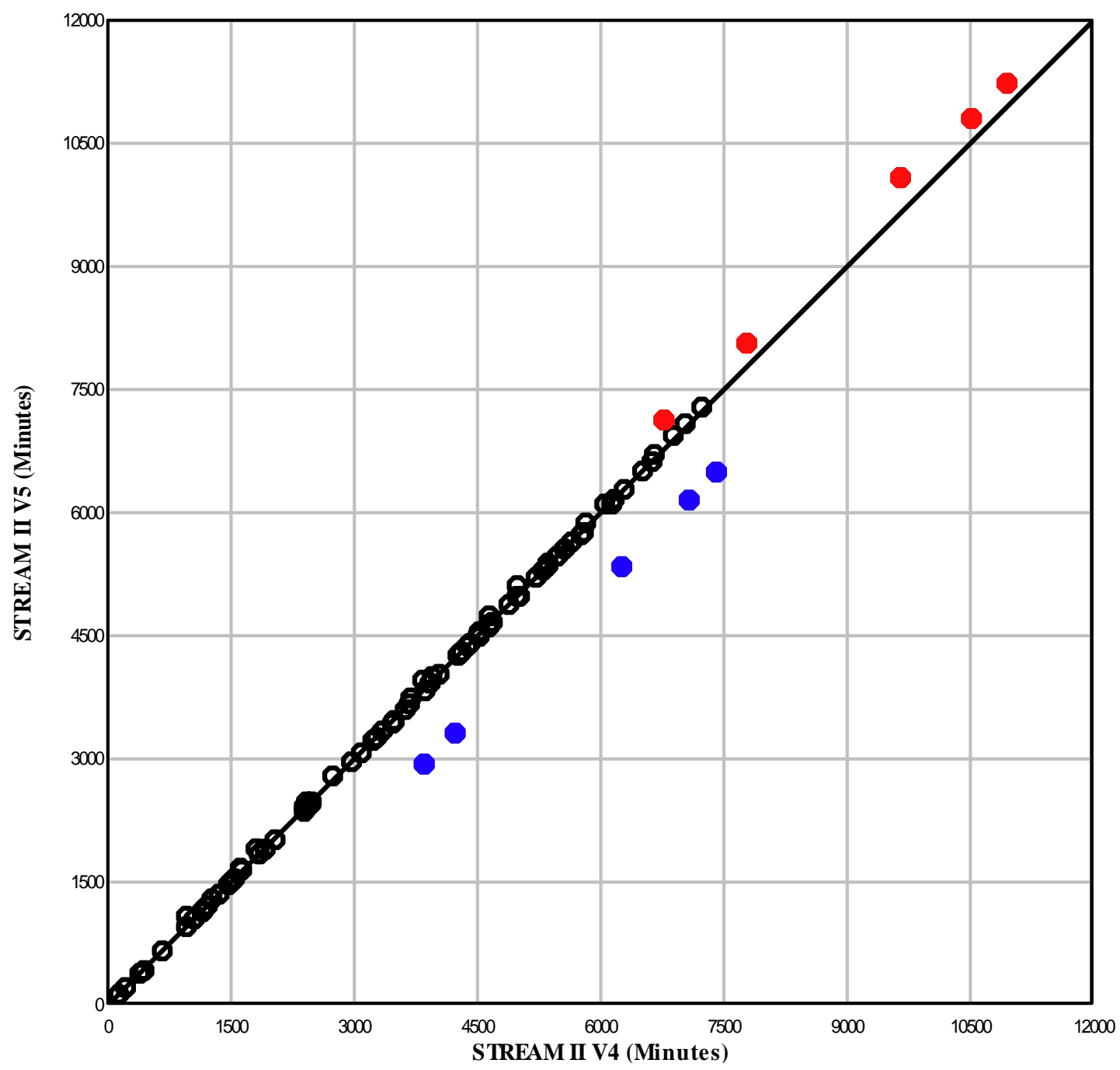

Note:

The blue dots represent the simulation results for a release into the Lower Three Runs, and the red dots represent the simulation results for a release into the Pen Branch. In STREAM II-V5, the segment volumes were varied as a function of flow. However, for STREAM IIV4, the segment volumes were also varied as a function of flow except the Pen Branch, Steel Creek and Lower Three Runs. As a result, predictions of the peak concentration and peak concentration arrival time are not in good agreement between these two versions. 
Figure 50

Effects of Rainfall on the Predicted Peak Concentration Arrival Time Rainfall vs No Rainfall

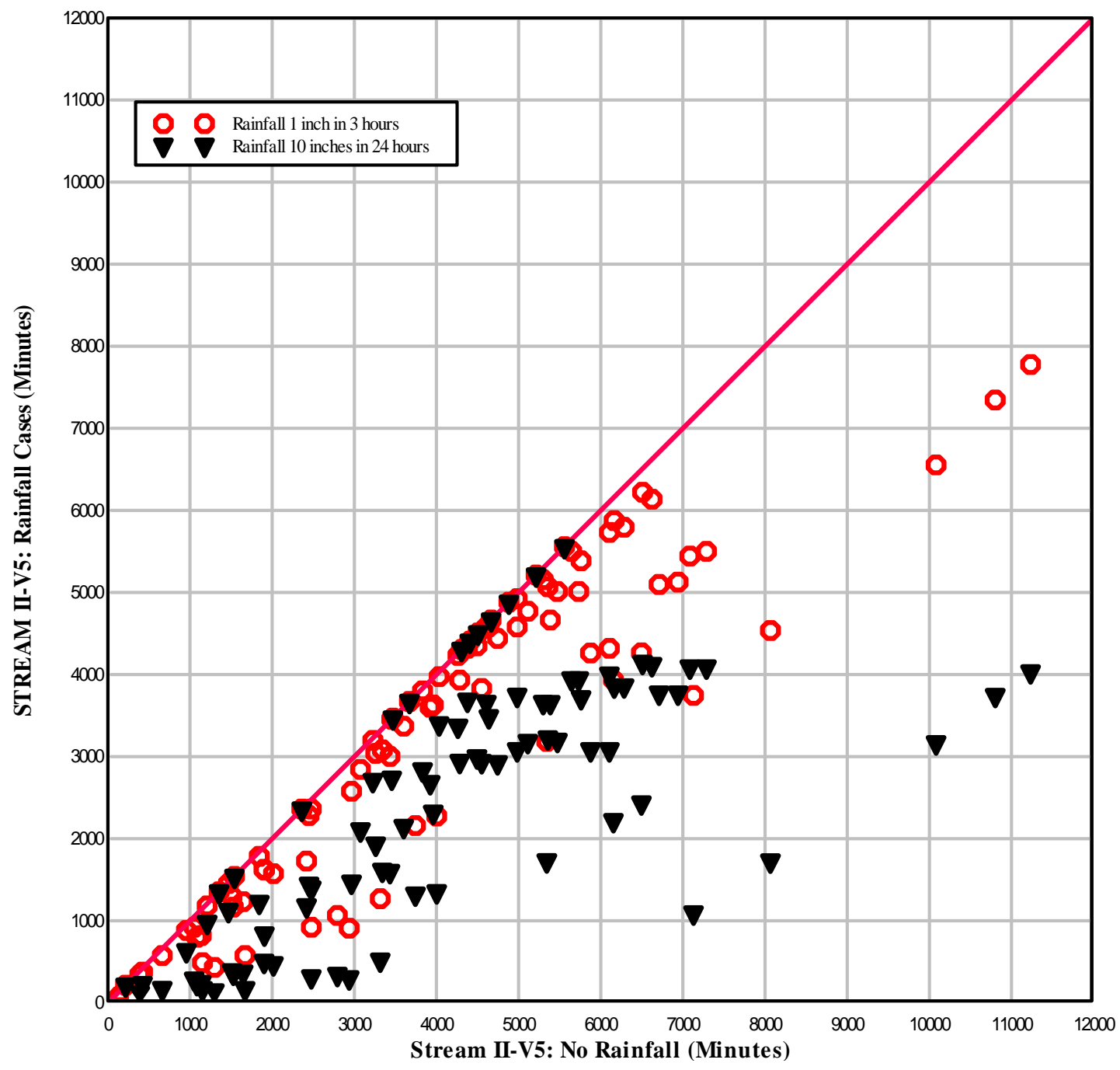


Figure 51

Effects of Rainfall on the Predicted Peak Concentrations Rainfall vs No Rainfall

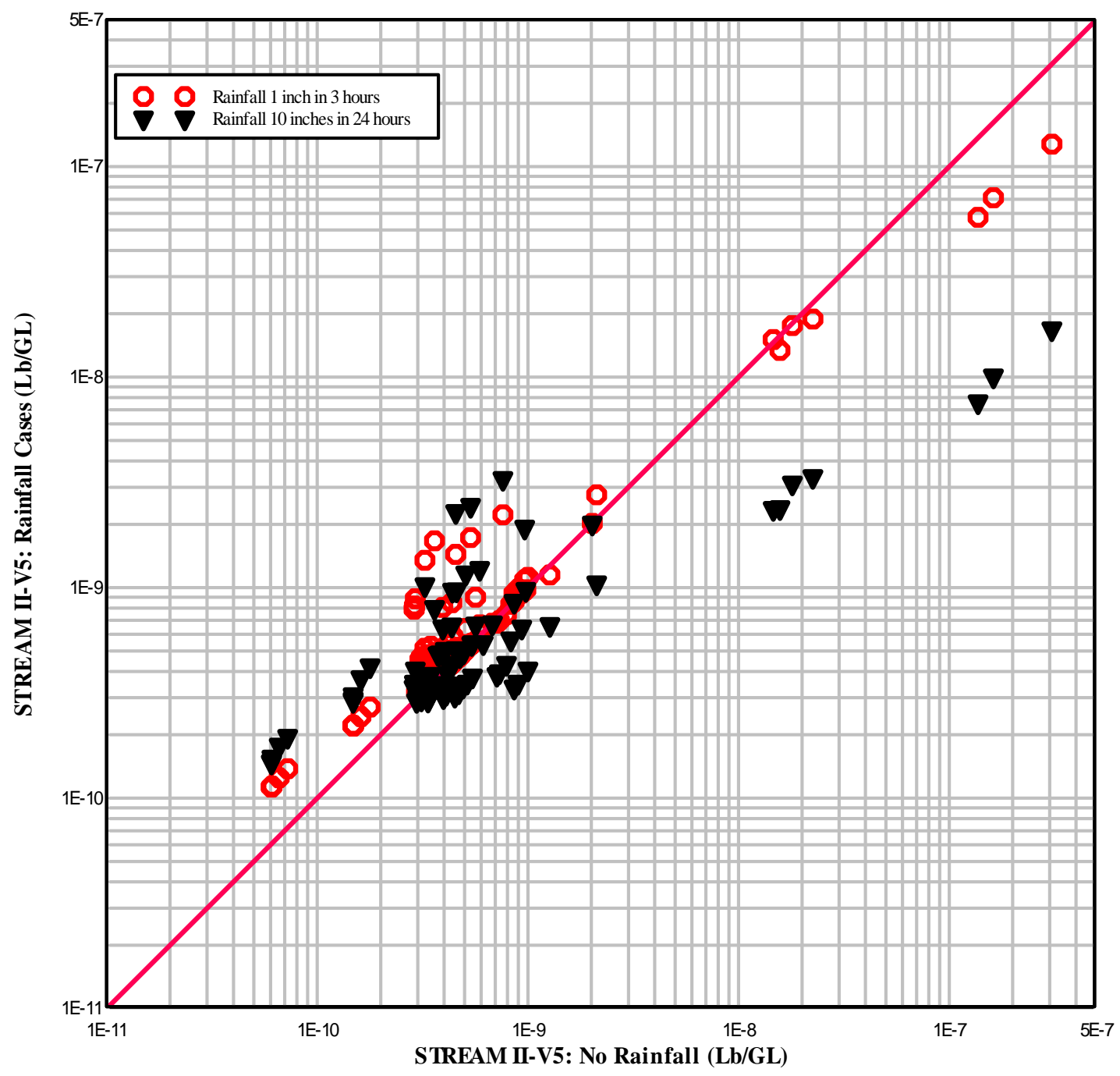


SAVANNAH RIVER NUCLEAR SOLUTIONS

Report SRNL-STI-2010-00116

DISTRIBUTION

SAVANNAH RIVER SITE

R. P. Addis, 773-A

C. H. Hunter, 773-A

R. L. Buckley, 773-A

E. D. Kabela, 773-A

S. R. Chiswell, 773-A

Kuo-Fu Chen, 773-A 